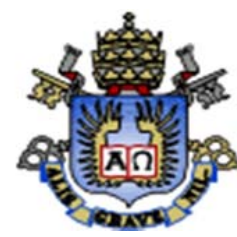

Rosa Lucia Soares Paiva

Da escuridão da violência à luz do fim do túnel: As vicissitudes de crianças de uma favela carioca

Dissertação de Mestrado

Dissertação apresentada como requisito parcial para obtenção do grau de Mestre pelo Programa de Pós-Graduação em Psicologia (Psicologia Clínica) do Departamento de Psicologia do Centro de Teologia e Ciências Humanas da PUC-Rio.

Orientadora: Profa. Maria Helena Rodrigues Navas Zamora 


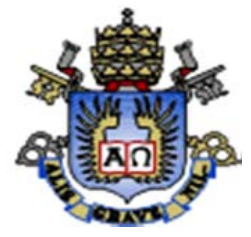

Rosa Lucia Soares Paiva

\section{Da escuridão da violência à luz do fim do túnel: As vicissitudes de crianças de uma favela carioca}

Dissertação apresentada como requisito parcial para obtenção do grau de Mestre pelo Programa de PósGraduação em Psicologia (Psicologia Clínica) do Departamento de Psicologia do Centro de Teologia e Ciências Humanas da PUC-Rio. Aprovada pela Comissão Examinadora a baixo assinada.

Profa. Maria Helena Rodrigues Navas Zamora

Orientadora

Departamento de Psicologia - PUC-Rio

Profa. Maria Inês Garcia de Freitas Bittencout Departamento de Psicologia - PUC-Rio

Profa. Maria Vitória Campos Mamede Maia Departamento de Faculdades de Educação - UFRJ

Profa. Denise Berruezo Portinari Coordenadora Setorial de Pós-Graduação

e Pesquisa do Centro de Teologia e Ciências Humanas - PUC-Rio 
Todos os direitos reservados. É proibida a reprodução total ou parcial do trabalho sem a autorização da universidade, da autora e do orientador.

\section{Rosa Lucia Soares Paiva}

Graduou-se em Psicologia pela Universidade Gama Filho em 1997. Cursou MBA em Gerenciamento de projetos pela Fundação Getúlio Vargas em 2008. Coordenou em parceria com Ministério Publico Conselho Tutelar de Vila Isabel e $2^{\text {a }}$ Vara da Criança e do Adolescente do Rio de Janeiro, o Projeto Casa das Crianças Rio Azul para crianças vítimas de violência doméstica e abuso sexual, projeto vinculado com a Fundacion Márgenes y Vínculos Spaña (www.fmyv.es). Professora Titular do curso Aprimore do RJ. Participação no Projeto LIPIS- Laboratório Interdisciplinar de Pesquisa e Intervenção Social PUC-RJ.

Ficha Catalográfica

Paiva, Rosa Lucia Soares

Da escuridão da violência à luz do fim do túnel: as vicissitudes de crianças de uma favela cariocas I Rosa Lucia Soares Paiva; orientador: Maria Helena Rodrigues Navas Zamora. - 2014.

$148 \mathrm{f.} ; 30 \mathrm{~cm}$

Dissertação (mestrado) - Pontifícia Universidade Católica do Rio de Janeiro, Departamento de Psicologia, 2014. Inclui bibliografia

1. Psicologia - Teses. 2. Infância. 3. Violência. 4. Tendência antissocial. 5. Delinquência. 6. Favela. I. Zamora, Maria Helena Navas. II. Pontifícia Universidade Católica do Rio de Janeiro. Departamento de Psicologia. III. Título. 
Aos meus pais amados, meu irmão Marcelo Paiva e ao Halff (in memoriam), pelo amor, carinho e todo apoio que me deram em todo o percurso dessa dissertação. 


\section{Agradecimentos}

À professora e doutora Maria Helena Zamora, pela primorosa orientação, compreensão e pelo acolhimento que me proporcionou nos momentos decisivos desse trabalho.

À professora e doutora Junia de Vilhena, pelo cuidado e paciência e por ter me aceito como sua orientanda no início desse trabalho.

Ao Capes e à PUC-Rio, pelos auxílios concedidos, sem os quais este trabalho não poderia ter sido realizado.

Ao meu irmão e melhor amigo Marcelo Paiva, pelas noites lendo meus capítulos, com paciência, carinho, amizade e acima de tudo cumplicidade.

Ao meu amigo Pedro D’Ávila pelo carinho, afeto e imensurável apoio em todos os momentos que precisei na confecção desse trabalho.

À minha amiga, professora, ouvinte e confidente Claudia Corbisier, por ter sido minhas mãos nos momentos difíceis de minha caminhada nesses dois anos de mestrado.

Ao meu amigo e supervisor Sergio Gomes. Sem ele, esse trabalho não teria sido possível. Seu carinho, atenção, ajuda com livros e textos e principalmente dandome holding quando precisei, foram cruciais para que eu continuasse e acreditasse nessa jornada.

À Aline de Leo, que sem seu apoio eu não teria conseguido chegar ao mestrado.

Ao meu noivo José Fernandes, que apesar das dificuldades, hoje é um dos meus maiores incentivadores.

A toda a família do Projeto Social do Circo, Ana Paula Pereira, Lígia, Ricardo, Camila, Graziele, Sandra, Christiano, Marcelo e aos meninos e meninas do Circo Social do Cantagalo.

Aos amigos e moradores do Morro do Cantagalo, e principalmente aos meus pacientes e suas famílias, pela credibilidade e confiança em meu trabalho. 


\section{Resumo}

Paiva, Rosa Lucia Soares; Zamora, Maria Helena Rodrigues Navas. Da escuridão da violência à luz do fim do túnel: As vicissitudes de crianças de uma favela carioca. Rio de Janeiro, 2014. 148p. Dissertação de Mestrado - Departamento de Psicologia, Pontifícia Universidade Católica do Rio de Janeiro.

O presente trabalho visa analisar, à luz da teoria do desenvolvimento maturacional infantil e da tendência antissocial de Winnicott, o comportamento antissocial e delinquente de crianças e adolescentes, moradores de uma favela, localizada na Zona Sul da cidade do Rio de Janeiro. Eles foram atendidos pelo serviço de psicologia clínica oferecido pelo projeto social de uma certa ONG. Tais crianças também têm em comum a violência, em suas várias manifestações, incidindo sobre suas vidas. Inicialmente foi descrito o local, o projeto em seu contexto, bem como as condições de atendimento. Foi utilizado o método de estudo de casos múltiplos em psicanálise, com o objetivo de obter uma melhor e mais ampla compreensão das dimensões psicossociais que o atendimento como um todo, pôde oferecer a essas crianças e adolescentes. O projeto seria um lugar onde a subjetividade desses jovens, marcada pelo sofrimento psíquico, a de-privação e as inúmeras formas de violência, encontram um espaço de escuta, acolhimento e uma possibilidade de (re)construção pela via da criatividade.

\section{Palavras-chave}

Infância; violência; tendência antissocial; delinquência; favela. 


\section{Abstract}

Paiva, Rosa Lucia Soares; Zamora, Maria Helena Rodrigues Navas (Adivisior). From the darkness of violence to the light of the end of the tunnel: The vicissitudes of children in a Rio slum. Rio de Janeiro, 2014. 148p. Master Thesis - Departamento de Psicologia, Pontifícia Universidade Católica do Rio de Janeiro.

The purpose of this study is to analyze, under Winnicott's theoretical standpoint of infant development and antisocial tendency, the antisocial and delinquent behaviors of infant and teenage residents of a slum (favela) located in the southern zone of the city of Rio de Janeiro. These children and teenagers - all treated by the clinical psychology service offered by a social project of a nonprofit organization - have in common the violence, under its several manifestations, touching their lives. A multiple case study method in psychoanalysis was used aiming to obtain an improved and broader comprehension of the psychosocial dimensions that the treatment as a whole could offer these children and teenagers. The project was held in a location where the subjectivity of these youths - marked by psychic suffering, deprivation, and several forms of violence - found a space of listening, welcoming, and the possibility of (re)construction through creativity.

\section{Keywords}

Childhood; violence; antisocial tendency; delinquency; favela (slum) 


\section{Sumário}

$\begin{array}{ll}\text { I. Introdução } & 10\end{array}$

II. A vida em uma favela da zona sul carioca 16

2.1. O Cantagalo - Bem vindo à favela! 20

2.2. Os tortuosos caminhos a percorrer 22

2.3. Como subir o Morro do Galo? 28

2.4. O trabalho do Circo Social: Como tudo funciona? 34

III. A violência de todo dia: as vicissitudes de crianças e 38 adolescentes moradores do Cantagalo

3.1. O poder do tráfico de drogas: Quem manda na favela? 42

3.2. A Polícia Militar do Rio de Janeiro (PMER): Um breve histórico 50

3.3. Das raízes artísticas da favela à brutalidade da violência 52

IV. A Teoria do Desenvolvimento Maturacional Infantil de 58 Winnicott

4.1. Preocupação Materno Primária (a doença de ser mãe) 61

4.2. Os processos do desenvolvimento emocional primitivo 67

4.3. As raízes da agressividade 76

4.4. A tendência antissocial 83

4.5. A delinquência como sinal de esperança 85

V. Método, Participantes e Descrição dos Atendimentos 87 Clínicos

5.1. O Método de estudos de casos múltiplos em psicanálise 87

5.2. Participantes, Encaminhamento e Descrição dos atendimentos clínicos: os meninos e meninas do Projeto do Circo social

VI. Análise e Discussão dos Casos Clínicos 119

$\begin{array}{ll}\text { VII. Conclusão } & 134\end{array}$

VIII. Glossário 139

$\begin{array}{ll}\text { IX. Referências Bibliográficas } & 144\end{array}$ 
"E ele não sabendo que era impossível, foi lá e fez."

(autor desconhecido). 


\section{1 Introdução}

A presente pesquisa surgiu a partir da nossa experiência durante dezesseis anos como psicóloga clínica no chamado Terceiro Setor, que no Brasil, em geral, compreende as associações sem fins lucrativos e/ou as organizações não governamentais (ONGs). As ONGs são consideradas em sua grande maioria, como uma consequência do fracasso do Estado em promover ações sociais ou políticas públicas, que atendam à população.

Em nossa trajetória profissional, dentro das chamadas comunidades pobres e faveladas, atuamos em uma organização não governamental na favela do Cantagalo, situada na zona sul carioca, no projeto que aqui chamaremos de Circo Social (ou simplesmente Circo), no serviço de psicologia.

Esta dissertação tem início com uma descrição de embasamento etnográfico, utilizando-se como registro para essa construção, feita no período de 2010 até 2013, um instrumento denominado “diário de bordo”. No diário, foram descritas todas as nuances da paisagem da favela, desde a chegada da pesquisadora no "pé do Morro", as suas vielas, as suas casas, as pessoas encontradas pelo caminho da subida da favela, até a chegada ao local em que o projeto em questão encontra-se instalado. Foram também feitas anotações dos casos a serem analisados, nos quais os comportamentos das crianças foram descritos; incluindo os respectivos acompanhamentos pelo Serviço de Psicologia, em conjunto com suas famílias que foram inseridas no projeto do circo social.

A questão principal da pesquisa é compreender e identificar as vicissitudes vividas por essas crianças, e como o trabalho feito dentro do projeto e dos atendimentos psicoterápicos possibilitou a elas terem seus comportamentos modificados, com criatividade e saúde, na medida em que puderam ter contato com um ambiente de provisão adequado.

Utilizamos nesta dissertação o método de estudo de casos múltiplos em psicanálise, descritos em Verztman, Pinheiro, Saceanu e Viana (2005). Para a compreensão das vicissitudes das crianças e adolescentes envolvidos, consideramos importante e consoante com nosso norte teórico e metodológico: o papel do 
atendimento do serviço de psicologia, o do projeto do circo social, os discursos e atos das crianças, suas relações familiares, a dinâmica violenta estabelecida pelo tráfico de drogas, a polícia e as próprias condições de privação, assim como a pobreza existente na favela.

A compreensão de um sentido mais profundo deste trabalho social nos levou à eleição do referencial teórico centrado na obra de Donald Winnicott, pediatra e psicanalista inglês (1896-1971) que ao formular sua teoria, teve sua contribuição particular com relação ao desenvolvimento do indivíduo e às questões sociais. Ele exerceu a carreira de medicina até o início dos anos 30 quando finalizou sua formação como psicanalista. Ao final da segunda guerra, que durou de 1939 a 1945, ele já tinha escrito vários artigos de cunho psicanalítico, sob a influência das teorias de Melanie Klein, e que se encontram na primeira parte do livro Da Pediatria á Psicanálise (1947a/2000). No decorrer dos seus atendimentos clínicos, constatou que seus conhecimentos de pediatria não eram suficientes para resolver os transtornos com os quais se deparava. Os comportamentos antissociais, apresentados pelas crianças que ficaram órfãs e soltas na cidade de Londres, foram vistos por Winnicott, principalmente com o fim da guerra. Essas crianças e adolescentes apresentavam, entre outros problemas psicológicos, comportamentos antissociais. A partir desse referencial clínico, pôde tratar de forma mais eficaz esse universo dos jovens traumatizados pela guerra e suas vicissitudes.

Em função desse histórico, destacaremos a ênfase dada por Winnicott ao ambiente cercado pela violência. É nesse ambiente, que as crianças e adolescentes, vivem na favela do Cantagalo e são atendidas pelo projeto do Circo Social.

O trabalho realizado no Circo consiste em aulas realizadas a partir de um trabalho pautado no lúdico, ou seja, as crianças e adolescentes inscritos participam de atividades de criação de figurinos, brincadeiras, danças, atividades circenses, dentre outros, com o objetivo de que esses meninos e meninas possam, através da arte e do brincar, encontrar a possibilidade da manifestação de sua vida criativa. Entendemos que nesse novo contexto, cria-se também um total contraponto ao cenário da violência que habita seus ouvidos e corações.

Winnicott considera o ambiente suficientemente bom, fundamental para o desenvolvimento de um indivíduo saudável. É a partir dessa visão, que o circo 
social, e toda a provisão ambiental proporcionada pelo projeto, que inclui o serviço de psicologia, pôde possibilitar a esses meninos e meninas um espaço de criação, possibilidades de mudanças efetivas em suas vidas e consequentemente de seus futuros.

O brincar criativo e a experiência cultural, segundo Winnicott (1962a) estão localizados no espaço potencial existente entre a mãe e o bebê. O uso que uma criança faz de um objeto transicional, a primeira possessão não-eu, representa o primeiro uso de um símbolo, bem como a primeira brincadeira. A característica essencial do brincar refere-se a uma experiência criativa na continuidade espaçotempo, uma forma básica de viver.

O atendimento psicológico está atento às perdas e falhas ambientais, reforçando a relação de confiança com os jovens, procurando constituir ali um espaço de acolhimento. Ressaltamos a importância de sempre observar a vertente teórico-metodológica adotada, o tipo de demanda em cada contexto, a singularidade de cada caso. Essa estratégia vem sendo a bússola utilizada pelo serviço de psicologia da ONG no projeto.

O Serviço de Psicologia é totalmente gratuito para os moradores da comunidade, bem como para a rede de parceiros que a ONG possui: escolas, associação de moradores, creches, CRAS (Centro de Referencia à Assistência Social) e o Posto de Saúde inserido na favela.

As entidades públicas ou privadas, tais como Escolas, Postos de Saúde, e outras ONGs próximas, os denominados parceiros da ONG, encaminham crianças e adolescentes para atendimento psicológico. As queixas mais comuns são faltas escolares e transtornos ligados ao comportamento dito antissocial das crianças que, muitas vezes, estão ligadas ao tráfico, ou tiveram a violência como vetor constitutivo em suas vidas.

O psicólogo inserido na equipe interdisciplinar possui a indicação de atuar de forma integrada com os outros profissionais, seja no momento do atendimento, no processo de condução dos casos, nas intervenções e nos encaminhamentos que forem necessários, após o término das avaliações multidisciplinares.

Devemos considerar que a inserção do profissional de psicologia nas atividades culturais, tanto no planejamento quanto na execução, assim como 
qualquer atividade de construção de espaços de reflexão e crítica, vem se constituindo também como estratégias de intervenção. Essas intervenções são obrigatoriamente dirigidas à garantia da promoção coletiva de um modo igualitário, democrático e participativo nas atividades. Dessa forma, promove-se a manutenção dos serviços e direitos fundamentais da população usuária dos serviços prestados pela ONG, levando-se em consideração as questões sociais como pano de fundo para o comportamento antissocial e delinquente de crianças e adolescentes atendidos pelo projeto.

Assim, o primeiro capítulo desta dissertação trará um histórico da construção das favelas no Rio de Janeiro, uma descrição do alicerce etnográfico da favela estudada, e do funcionamento do projeto social do Circo Social da ONG pelo meio de seu Núcleo Social de trabalho no Cantagalo, que atende crianças e adolescentes que sofrem os efeitos da violência.

No segundo capítulo abordaremos algumas formas de violência vivenciada pelas crianças da favela em questão, a violência estrutural, a violência do tráfico de drogas, a violência familiar, a violência de gênero, bem como a violência da polícia, tendo como referência a abordagem de diferentes autores que discutem o tema tais como, Alves (2013), Burgos, Almeida, Cavalcanti, Brum e Amoroso (2011), Costa (1993, 1997), Dahlberg e Krug (2006), Machado e Evason (2008), Freire (2007), Maia, Zamora e Vilhena (2007), Netto e Braz (2008), Neto e Moreira (1999), Rios (2012), Silva (2004, 2007, 2009), Vilhena, Zamora e Bittencourt (2011), Vilhena, Zamora e Dimenstein (2005), Vilhena e Santos (2000), Vilhena (2003), Wacquant (2001) e Zamora e Canarim (2009).

No terceiro capítulo, trataremos da teoria sobre o desenvolvimento maturacional infantil, a tendência antissocial e comportamento delinquente segundo a teoria clínica proposta por Winnicott.

O quarto capítulo será dividido em diversos tópicos: a metodologia utilizada de estudo de casos múltiplos em psicanalise, o perfil (nome, sexo e idade) de cada criança e adolescente, no relato dos encaminhamentos realizados pelos diferentes atores que compõe a rede de profissionais que atuam na favela do Cantagalo, na exposição do histórico familiar desses meninos e por fim na descrição dos procedimentos psicoterapêuticos utilizados ao longo dos atendimentos clínicos. 
No quinto capítulo, apresentaremos os resultados desses acompanhamentos, ou seja, a análise dos casos, em conformidade com a teoria Winnicottiana, a partir do método de “estudo de casos múltiplos em psicanálise”, conforme mencionamos anteriormente. Enfatizaremos, sobretudo, o trabalho de acolhimento, de saúde, de possibilidades e, principalmente, do exercício da criatividade, alcançado pelo projeto do Circo Social na vida dessas crianças e adolescentes.

Apoiando-nos na teoria de desenvolvimento emocional e na da tendência antissocial e comportamento delinquente, iremos demonstrar como cada caso foi atendido a partir dessas teorias, em parceria com as atividades de arte e cultura realizadas no circo social. “Acreditamos que a arte permite a transformação do self lesado, como se fora um sonho de elaboração: as atuações dão lugar à simbolização e à representação” (OUTEIRAL, 2011, p.312).

Simultaneamente, apresentaremos na leitura de um dos casos de uma criança, as limitações de atuação do psicoterapeuta. Quando o caso torna-se crônico, e a criança simplesmente não consegue suportar o acolhimento, não somente terapêutico, como do próprio trabalho do projeto do circo, tendo como um dos principais empecilhos a não participação de sua família. Família essa que, pelo que percebemos, não encontrou um movimento saudável para a possibilidade de transformação e progresso emocional desta criança.

O trabalho executado pelo projeto do circo foi então, de grande importância na vida dessas crianças. Propusemos a ideia de que poderíamos considerar esse lugar como: “o espaço transicional”, para esses meninos que vivenciaram tantas dificuldades de relacionamento com seus familiares e, principalmente, com a violência que vivenciaram e vivenciam na própria favela.

Recordando a fala de Winnicott, quando diz que é no período da passagem da adaptação absoluta para a relativa, que os objetos transicionais adquirem um status indispensável de função de amparo, por substituírem a mãe que se desadapta e desilude o bebê. É a passagem da “desmistura” tal qual Dias (2012) se refere ao falar da quebra da unidade mãe-bebê.

Desse modo, para que este espaço tenha significação, é necessário que esteja baseado num sentimento de confiança e de provisão saudável do ambiente. O circo pode ser visto como um espaço de jogo, onde através do lúdico as crianças e 
adolescentes, puderam resignificar suas vidas, tendo sido ajudadas por novas experiências.

Esperamos, com esse trabalho, ter uma melhor e mais ampla compreensão das dimensões sociais e principalmente subjetivas do comportamento antissocial e delinquente das crianças e adolescentes estudados. Mostraremos como o trabalho realizado pela equipe técnica social, em particular o serviço de psicologia da ONG na favela, vem se tornando "a luz do fim do túnel” para muitas crianças, adolescentes e suas famílias do universo da favela do Cantagalo. 


\title{
2
}

\section{A vida em uma favela da Zona Sul carioca.}

\author{
Não Há um Canto da Favela \\ Não há um canto da favela \\ Que não guarde uma história \\ Não há um canto da favela \\ Que não tenha um conto pra cantar \\ Josy Manhães- Museu da Favela - MUF
}

Na referida pesquisa, discorrer sobre o surgimento das favelas e morros na cidade do Rio de Janeiro nos auxilia em uma compreensão mais ampla, de como as reformas urbanas adotadas durante o final do século XIX nos aproximaram do que atualmente se vivencia com a exclusão do chamado "favelado" e “marginalizado” das grandes cidades, em nosso caso, o Rio de Janeiro.

O surgimento das favelas aconteceu a partir de reformas urbanas no Rio de Janeiro que datam do final do século XIX e início do século XX e do projeto higienista operado pelo então prefeito Francisco Pereira Passos. Essas reformas e esse projeto tinham como principal objetivo o embelezamento e modernização da capital do Brasil à época. Marcadas pela derrubada dos cortiços e casebres pobres da cidade, e desalojamento da população moradora destes espaços, tais reformas produziram grandes transformações na organização urbana da cidade. Até então, de acordo com Valladares (2000), os trabalhadores pobres, os considerados vadios e malandros abrigavam-se nos cortiços, representados por isso como lócus da pobreza e chamados por alguns de "inferno social”.

A partir dos desalojamentos desta população envoltos em um “mito de origem”, onde as favelas parecem ter um início ainda pouco conhecido, com os 35 ex-combatentes da Guerra de Canudos - estes interessados em pressionar o Ministério da Guerra a pagar os soldos de guerra devidos - ela passa a ocupar o morro localizado aos fundos desse Ministério, que batizaram de morro da Favela. Valladares (2005) em obras um pouco mais recentes esclarece que apesar do morro da Favela, hoje morro da Providência, ser o mais conhecido, a Quinta do Caju, a Mangueira e a Serra Morena também datam do século XIX e são todas anteriores ao morro da Favela. O povoamento dessas zonas começou em 1881. Os primeiros habitantes eram imigrantes portugueses, espanhóis e italianos tanto na Quinta do 
Caju, quanto na Mangueira, o que nos permite supor que o seu estabelecimento nessas áreas tenha sido autorizado pelo Estado na época. No entanto, foi o morro da Favela que entrou para história.

Valladares (2005) analisa a correlação entre o mito em torno do morro da Favela, ocupado também por ex-combatentes da guerra de Canudos, e a obra Os Sertões, de Euclides da Cunha, publicada pela primeira vez em 1902, centrada ao mesmo tempo sobre o espaço hostil do sertão e sobre o sertanejo. Afirma que este livro foi tido como o "número um” do Brasil, com mais de 30 edições e lido pela maior parte dos intelectuais da época. Representou um sinal de alerta para a elite política brasileira, pois o personagem principal, Antônio Conselheiro, representado como líder religioso e carismático era o responsável pela feroz resistência da população de Canudos que derrotou quatro exércitos enviados pelo governo da República, recém-construída e derrotada por esses “selvagens”. A possibilidade de sublevação de um povo miscigenado e, para a época, inferior e que provocava temor.

Assim, a união entre os ditos pobres, malandros e vagabundos, e os excombatentes de uma guerra representada pela resistência da organização popular, parece ter causado preocupação e receio, tendo contribuído na construção sobre o mito do morro da Favela.

De acordo com Mattos (2009), em 1905 os impactos sociais das reformas urbanas passaram a ser percebidos mais claramente pela sociedade carioca. Instaurou-se um forte clamor popular relacionado com o agravamento da crise de moradias, e as classes dominantes perceberam que as reformas urbanas haviam gerado consequências indesejadas para o seu projeto de Rio de Janeiro, que pretendia incluir a cidade no processo de “civilização”.

Havia uma insatisfação nas pessoas que acreditavam de algum modo na possibilidade de uma reconstrução da capital de uma maneira ideal. "Para a insatisfação daqueles que acreditavam na possibilidade de reconstrução da capital em tais termos ideais, houve a constatação de que estava em pleno andamento a primeira grande expansão das favelas no cenário urbano carioca” (MATTOS, 2009, p.152). Isso contribuiu para que as favelas ficassem em evidência na grande imprensa, sendo considerados símbolos do "antiprogresso" e da "anticivilização". A civilização, idealmente, era a cidade de Paris, após intensa reforma. 
Podemos, a partir de o exemplo a seguir, ver como o passado ecoa no presente. Segundo Silva (2007), em estudo sobre representações e concepções sobre as favelas, realizou enquete informal com grupo de pessoas de distintos grupos sociais e categorias profissionais, com a seguinte questão: o que é uma favela? A partir das respostas fornecidas, o autor verificou que existe um quadro consensual de opiniões sobre esse espaço popular. Independente da posição política, da condição educacional, da perspectiva ética e religiosa, existia um considerável padrão na forma como esse espaço era representado.

A análise das respostas revelou que o eixo paradigmático dessa representação compartilhada era a noção de ausência. “A favela é definida pelo o que ela não é e pelo o que ela não tem” (SILVA, 2007, p.4). Nesse caso, foi definida como espaço destituído de infraestrutura urbana, globalmente miserável, sem ordem, sem lei, sem regras, sem moral, como expressão do caos. Outro resultado significativo dessa investigação foi à noção de homogeneização, segundo a qual todas as favelas seriam iguais em seus aspectos físicos e sociais.

Silva (2007) observa também como as representações encontradas em seu estudo estão presentes desde as primeiras formulações oficiais sobre as favelas, e exemplifica com demonstração da definição apresentada no censo das favelas de 1950.

São consideradas favelas todos os aglomerados urbanos que possuam, total ou parcialmente, as seguintes características: proporções mínimas: agrupamentos prediais ou residenciais formados com unidades de número geralmente superior a 50. Tipo de habitação: predominância, no agrupamento, de casebres ou barracões de aspecto rústico, construídos principalmente de folhas de flandres, chapas zincadas, tábuas ou materiais semelhantes. Condição jurídica de ocupação: construções sem licenciamento e sem fiscalização, em terrenos de terceiros ou de propriedade desconhecida. Melhoramentos públicos: ausência, no todo ou em parte, de rede sanitária, luz, telefone e água encanada. Urbanização: área não urbanizada, com falta de arruamento, numeração ou emplacamento. (Censo 1950, Departamento de Geografia e Estatística da Prefeitura do Distrito Federal in: SILVA, 2007, p.4).

Os autores Pandolfi e Grynszpan (2003) chamam a atenção para os efeitos dessas representações sobre as favelas e os favelados aos que se dirigem. Lembram, contudo, que o que é observável e verdadeiro constitui, por um lado, uma pauta de graves problemas a serem solucionados; por outro, fazem notar que a opacidade da favela está justamente no destaque que ela possui advindo da mídia, do Estado e de muitas ONGs, como sendo um “problema” Pandolfi e Grynszpan 
(2003, p.21), um olhar parcial sobre a realidade da favela. Porém, a despeito de ser parcial, ela produz a certeza de e qujá conhecemos a favela a priori, como se não fosse necessário conhecê-la efetivamente em sua inteireza e complexidade.

Ela induz e direciona o nosso olhar, condicionando o que ver e como ver; levá-los a perceber e tratar como unidade a favela e os favelados, aquilo que, de fato, é marcado por uma extrema diversidade. A representação sobre a favela impõe-se, assim, à realidade das favelas (PANDOLFI, RYNSZPAN, 2003, p.23).

Diante desse cenário, consideramos importante indagar em que medida é possível romper com as representações sociais hegemônicas nas produções dessas subjetividades. Consideramos importante observar que um dos atravessamentos constituintes dessas produções de subjetividades, das construções destes indivíduos e coletividades, das concepções hegemônicas sobre as favelas, são concepções que criminalizam esses territórios e seus habitantes, seja por suas dimensões violentas ou apenas por sua localidade, ou seja, o morro.

A favela é uma comunidade, assim como Ipanema, bairro da zona sul do Rio de Janeiro. Birman (2008) se debruça sobre a questão "favela é comunidade?”, analisando mais os processos de identificação do que as identidades propriamente ditas nestas classificações, verificando que:

a forma de identificar as pessoas e grupos não é uma atividade inócua, principalmente quando quem produz identificações deste teor, é o responsável maior pelo governo, aquele que tem, a princípio, maior poder de conformar a administração do Estado aos seus julgamentos (BIRMAN, 2008, p.100).

Apontamos então, para a necessidade de acompanharmos os processos de produção de subjetividades no comportamento das crianças da favela. São eles que sustentam toda a lógica engendrada de criminalização com fins de controle desta parcela da população, pobre, jovem, guetificada, que "sobra” no desenvolvimento político e econômico do país. Seguindo neste acompanhamento, observamos com Batista (2003) o sucesso das políticas fundamentadas na lógica da criminalização da pobreza, ancoradas na produção de subjetividades amedrontadas e crentes de que, de fato, os pobres, negros, jovens, moradores de favelas, constituem as chamadas classes perigosas, representantes do grande mal da sociedade. Na obra da autora, encontramos uma análise histórica da construção do medo nesta cidade. Ela demonstra como, em várias instâncias, o medo produziu sentimentos, afetos, 
políticas econômicas, sanitárias e tomou conta da vida carioca desde a época escravagista.

\section{1}

\section{O Cantagalo - Bem vindo à favela!}

O Morro do Cantagalo, ou "favela do Galo", fica entre os bairros da Zona Sul da cidade do Rio de Janeiro mais conhecidos, que são Ipanema e Copacabana. É ali, na Rua Saint Roman, em Copacabana, que começa a subida do Morro e a história de cerca de cinco mil pessoas, segundo a estimativa estabelecida pela Associação de Moradores do Cantagalo, desde moradores antigos, que já vivem na favela há quase 50 anos, até os que constantemente chegam para morar vindos de todos os cantos do mundo. Dizem os moradores que os turistas que entram no Morro ficam encantados e não querem mais sair.

Quando foram construídos os primeiros barracos do Cantagalo, nos anos 30, o clima no morro ainda era rural, com ares de cidade pequena do interior. A maioria dos moradores cultivava pequenas hortas para subsistência. Muitos criavam galinhas. Como um deles na época tinha uma enorme criação de galos, o nome acabou pegando: "Lá onde canta o galo". Mas não há consenso sobre esta história ${ }^{2}$.

Antigos moradores afirmam que os primeiro moradores possuíam pequenas hortas, porcos, galinhas e galos, que tomavam conta das casas como cãesde-guarda. A qualquer sinal de aproximação, o galo cantava. A frase "Lá onde canta o galo” era comum para se referir ao local e essa é a mais provável origem do nome. O sambista brasileiro Bezerra da Silva, nascido no Morro, canta na música Aqueles Morros: “Gosto de todos, mas o Morro do Galo que é meu lugar”.

A nossa trajetória como pesquisadora na favela do Cantagalo, ou melhor, no "Morro do Galo”, começou no dia 14 de Março de 2010, quando a pesquisadora, em seu primeiro dia de trabalho, se deparou com as dificuldades, e ao mesmo tempo, com as possibilidades de “subir o morro” e chegar ao seu objetivo, que era o Núcleo Social da ONG.

\footnotetext{
${ }^{2}$ www.favelatemmemoria.com.br/publique/cgi/cgilua.exe/sys/start.htm?infoid=36\&sid=3
} 
Chegar a ONG incluía subir todo o Morro, cumprir todo o percurso que fora feito no dia anterior, durante a seleção de profissionais para esse trabalho.

Para trabalhar numa favela, é importante pesquisar o lugar, sua origem e também a origem das pessoas que moram ali. E trabalhar no Cantagalo, ligada a favela do Pavão-Pavãozinho, sempre foi para a pesquisadora algo intrigante, pois são duas favelas que coexistem em um mesmo território, mas que foram povoadas por distintas origens étnicas. A favela do Pavão-Pavãozinho foi povoada praticamente por migrantes do Nordeste do país. Famílias numerosas que construíram na favela suas raízes, que contam como seus avós chegaram ao Morro e de como a vida sem o tráfico de drogas era mais feliz.

Já no Morro do Cantagalo, a predominância é de afrodescendentes e imigrantes latino-americanos, tais como chilenos e paraguaios, em sua grande maioria. Há inclusive ruas na favela, onde praticamente só moram chilenos e paraguaios. O diálogo entre essas pessoas e os moradores brasileiros é extremamente interessante. Aparentemente convivem muito bem, sem atritos.

A grande maioria vive de vender artesanato na praia ou de trabalho como diaristas nas casas ricas do Cantagalo. “Casas ricas” são chamadas as casas que têm mais de dois andares. É muito comum subirmos o Morro e nos depararmos com essas construções imensas, nas quais os moradores vão construindo sua moradia em cima da casa de familiares. Uma filha que vai casar já sabe que pode construir sua própria casa em cima da casa de sua família. E assim o Morro vai crescendo verticalmente e as famílias aumentando.

\section{2}

Os tortuosos caminhos a percorrer: Uma clínica psicológica na Favela 
Como foi dito, a presente pesquisa surgiu da trajetória profissional da pesquisadora dentro das chamadas comunidades pobres e faveladas, especificamente em favelas tomadas pelo tráfico de drogas ilícitas.

O Cantagalo especificamente foi tomado como uma das favelas cariocas que passam pelo processo de pacificação promovido pela Secretaria de Segurança Pública do Estado, através das Unidades de Polícia Pacificadora (UPP). Segundo o que é dito pela Secretaria de Segurança Publica do Estado do Rio de Janeiro, o projeto da UPP tem como finalidade básica a retirada do tráfico de drogas ilícitas da localidade, a promoção da paz para os moradores e o fim da violência. O fim da violência passa a ser prioridade do Estado. Ou pelo menos é a que o texto faz referência:

a UPP um dos mais importantes programas de Segurança Pública realizado no Brasil nas últimas décadas. Implantado pela Secretaria de Segurança do Rio de Janeiro, no fim de 2008, o Programa das UPPs é planejado e coordenado pela Subsecretaria de Planejamento e Integração Operacional. O Programa das UPPs foi elaborado com os princípios da polícia de proximidade, um conceito que vai além da polícia comunitária e tem sua estratégia fundamentada na parceria entre a população e as instituições da área de Segurança Pública. (Secretaria de Estado de Segurança - SESEG, 2009).

Ressaltemos que o termo violência utilizado aqui, sobre o qual Costa (2003), em seu livro “Psicanalise e Violência” nos esclarece, não designa uma essência moral ou material com forma e conteúdo singularizados. A palavra violência é empregada para denominarmos uma cadeia de atos intencionais que se caracterizam pelo uso da força, em sua grande maioria quando o indivíduo se encontra em situação de conflito e transgressão às leis. Leis essas, que para o autor, que tem como objetivo comum o convívio solidário entre os homens.

O hábito que criamos de falar de Violência com "V" maiúsculo é uma defesa contra o medo. Defesa que termina indo de encontro às finalidades que lhes deram origem. Em vez de proteger-nos imaginariamente contra o Mal, a fantasia da Violência paralisa nosso pensamento e nossas ações, aumentando o sentimento de impotência (COSTA, 1993, p.86).

É especificamente no cenário da violência descrita por Costa, que tem como pano de fundo, a venda de drogas ilícitas por um grupo de pessoas denominado de "traficantes", que a ONG, com o projeto Circo Social descrita nesse trabalho, surgiu como uma entidade de auxílio, visando a promoção de mudanças 
na vida de crianças e suas famílias. O trabalho da ONG está inserido, em diversos projetos sociais, os quais possuem como base principal a inclusão de crianças e adolescentes em atividades primordialmente ligadas às brincadeiras: o lúdico e principalmente a arte como promovedora de distanciamento destes indivíduos do cenário da violência que os cerca.

Na porta de entrada da ONG, foi notada sua missão descrita por seu idealizador: “Onde muitos não vêem uma saída, nós vemos arte”. É no brincar que podemos manifestar a nossa criatividade e é somente no brincar que o indivíduo, seja ele criança ou adulto, pode ser criativo e utilizar a sua personalidade integral, ou dito de outro modo, é somente sendo criativo que o indivíduo descobre o seu verdadeiro “eu”.

O brincar e a criatividade fazem parte do desenvolvimento suficientemente bom, para usar um termo caro à Winnicott. É dessa criatividade que nós, os vinte profissionais que compusemos as equipes técnicas sociais que atuam nos projeto da ONG, utilizamos como pilar de base teórica de trabalho.

A ONG possuía uma equipe de técnicos em cada Núcleo, denominados de equipe técnica social. Os núcleos são compostos de profissionais da área de Pedagogia, Psicologia e Serviço Social que atuavam de forma permanente nos núcleos comunitários de cultura, planejando, executando e avaliando ações de atendimento, encaminhamento, acompanhamento e orientação. Essas atividades abrangiam não somente o público envolvido nas atividades culturais, mas também o universo particular e familiar e intercomunitário do público envolvido. Esse trabalho se caracterizou pela formação de redes sociais, pela promoção e pelo incentivo ao empreendedorismo.

A equipe técnica social atuou ainda em parceria com instituições de ensino e pesquisa, com a possibilidade, inclusive, de oferta de estágio supervisionado, visando à contribuição na formação e inserção acadêmicoprofissional dos sujeitos, bem como favorecer a relação teórico-prática, no desenvolvimento de metodologias especificas de trabalho nas comunidades.

A metodologia adotada na execução das ações de atendimento direto à população pela equipe técnica social na instituição teve como paradigma de orientação a interdisciplinaridade, que se caracteriza pelo desenvolvimento de ações conjuntas, integradas e inter-relacionadas de todos os profissionais envolvidos, 
como também em demandas específicas por área de atuação. Cabe salientar que a forma de intervir, os “olhares” e as “escutas” são sempre específicas de cada profissional, respeitando-se as particularidades de cada núcleo e, dessa forma, a contribuição de cada profissional em seu contexto e realidade.

No Núcleo da ONG, com o projeto do Circo Social, localizado na favela do Cantagalo, trabalhamos especificamente com circo social e dança, além de projetos de oficinas profissionalizantes de pintura cênica, reciclagem e iluminação artística. Importante ressaltar que, qualquer pessoa, não só os moradores da favela citada, podiam participar das atividades propostas no projeto. Os moradores do entorno da favela, também eram convidados a fazer parte das oficinas e subgrupos, como o circo profissional, propostos pelo projeto da ONG. O asfalto e o morro têm a arte como o elo entre dois mundos, que se diferem em suas peculiaridades, mas que se aproximam por se encontrarem situados no mesmo contexto, a zona sul carioca. E todos recebiam atendimento psicológico promovido pela equipe social dos Núcleos.

É importante ressaltarmos que, o psicólogo inserido na ONG, também atuava intervindo nas relações da instituição, em espaços formais de discussão e na análise das práticas dos educadores, tais como as reuniões de equipe/núcleo, os grupos de educadores e os espaços de formação, além de intervenções que aconteciam no próprio cotidiano, na dinâmica do núcleo. Esta forma de atuação integrada se fez necessária na discussão dos casos - um espaço de troca de saberes e experiências entre os profissionais. Este espaço possibilitava a delimitação das funções (o que é de competência de cada profissional), das responsabilidades (o que cada profissional se dispõe a fazer no caso), respaldando cada um deles na sua prática.

Outro ponto que merece destaque, e atravessa toda a prática da atuação do profissional de psicologia, é a questão do sigilo. Conforme determina o Código de Ética da profissão em seu artigo $9^{\circ}$ :

É dever do psicólogo respeitar o sigilo profissional a fim de proteger por meio da confidencialidade, a intimidade das pessoas, grupos ou organizações a que tem acesso no exercício profissional”. Sobre o relacionamento da psicologia com outros profissionais, o art. 6 $6^{\circ}$, b, nos diz que o psicólogo: “(...) compartilhará somente informações relevantes para qualificar o serviço prestado, resguardando o caráter confidencial das comunicações, assinalando a 
responsabilidade, de quem as recebe, de preservar o sigilo (Código de Ética Profissional dos Profissionais de Psicologia, 2010, p.35).

Assim sendo, o psicólogo deverá fornecer aos outros profissionais somente as informações que sejam estritamente necessárias ao andamento do caso.

Quanto aos atendimentos, as crianças moradoras da favela que eram acompanhadas pelo serviço, traziam, com grande expressividade, as consequências do que viviam em relação à violência, apresentando os seguintes comportamentos: pequenos roubos em casa, na escola e na própria favela, brigas e agressões a outras crianças e a dificuldade em compreender seus limites.

De acordo com Costa (1997), a violência “invadiu todas as áreas da vida de relação do individuo: relação com o mundo das coisas, com o mundo das pessoas com seu corpo e sua mente” (op.cit., p.86).

Para muitas famílias, o Núcleo passou a ser o "lugar seguro” para onde seus filhos eram encaminhados, fosse para as atividades recreativas, fosse para o serviço de atendimento em psicologia. Para essas famílias, a segurança que o lugar lhes oferecia, era constantemente afirmada em suas falas e comportamentos, principalmente quando retornavam ao Núcleo Social. Winnicott foi o autor que valorizou como nenhum outro o interjogo entre as forças do meio onde o sujeito esta inserido e o sujeito, ou seja, a importância do contexto em que o indivíduo está inserido para que o processo de desenvolvimento e amadurecimento pessoal aconteça Winnicott (1962b).

Para Winnicott, um ambiente suficientemente bom, é o fomentador da constituição emocional do indivíduo. Quando o ambiente, por algum motivo falha, essa constituição emocional é abalada. Quanto mais pobre (pobre no sentido qualitativo!) o ambiente, em termos de cuidado e acolhimento advindos da mãe ou de quem se coloca nesse papel, mais problematizada será a constituição emocional da criança. Winnicott em sua teoria do Desenvolvimento Maturacional, não relaciona um ambiente de pobreza econômica como não acolhedor, ou não facilitador e continente, mas sim a maneira como esse ambiente é vivenciado e a qualidade dessa interação entre a criança e o seu entorno. Esses fatores é que serão determinantes. As chamadas famílias-problema existem em todas as classes sociais. Logo, não podemos responsabilizar as condições da favela, pelas perturbações do seu desenvolvimento. 
Se há as chamadas "famílias-problemas" não se pode culpar inteiramente a autoridade local pelas condições de favela em que a criança é criada. O cuidado físico é afetado pela capacidade das crianças ou pais de recebê-las, e se verifica que ao redor da área, a que chamamos de cuidado físico, há o território complexo dos distúrbios emocionais do individuo, de grupos de indivíduos ou da sociedade (WINNICOTT, 1962, p.63).

A ONG, inserida na comunidade do Cantagalo, tornou-se um lugar de construção de possibilidades, de acolhimento e, principalmente, de perspectivas para uma vida melhor, com as atividades oferecidas nas oficinas de circo e dança. Safra (2005) afirma que o ambiente suficientemente bom, pode ser a mãe, o bairro, a cidade, ou seja, ele estabelece uma “arquitetura do ambiente acolhedor”.

O importante a assinalar é que o espaço do mundo só é visto pela criança como um campo a ser explorado porque ela sente que tem lugar e morada em seu corpo e no seu interior do corpo Materno. O espaço do mundo é visto como bom, porque contém também, analogamente, o aconchego do colo e do interior da mãe. Caso contrário, o mundo será vastidão infinita, lugar de horror. Algumas crianças, que ainda não experimentaram a possibilidade de encontrar morada no interior do corpo materno, não tem a noção de um espaço que possa ser habitado e lutam intensamente para encontrar o lugar que as acolha (SAFRA, 2005, p. 84).

A ONG com o projeto do Circo Social tornou-se, então, um espaço experimentado como suficientemente bom na vida das crianças e dos adolescentes, tendo a cultura e a arte como pano de fundo para a promoção de um ambiente saudável que estimula a criatividade. Esse espaço favoreceu também a elaboração das dores dessas crianças. Primordialmente, percebemos que o atendimento de uma clínica psicológica comprometida com a saúde mental é fundamental para que o processo de um espaço continente aconteça.

É uma tarefa árdua tentar promover saúde mental, por meio da cultura e da arte, de um atendimento psicológico clínico comprometido com a esperança e a melhora da vida emocional das crianças que são atendidas no Núcleo Social do projeto. Nesse contexto da favela, vida é difícil desde o início. Atuar numa clínica psicológica, dentro de uma favela que foi, durante anos, alvo de traficantes de drogas ilícitas, armados, e que se utilizavam de leis próprias para manter o seu poder, poderia ter sido inviável. Era como pensávamos antes de iniciar esses atendimentos.

Como promover a saúde mental de crianças que são encaminhadas para o Núcleo Social do projeto, no meio de tanta violência? E como auxiliar as famílias 
que veem seus filhos entrarem para o tráfico de drogas? Encontrando-se impossibilitadas muitas vezes, ou quase sempre, de impedi-los? A favela parecia pacificada, mas o “movimento” do tráfico de drogas ilícitas continuava. Víamos nas vielas, ao cair da tarde, meninos, adolescentes e crianças portando armas de fogo, com o objetivo de promover a segurança dos traficantes locais.

Essas crianças são as mesmas que, na escola, acabam demonstrando em seu comportamento antissocial, a marca da violência que vivenciam. Formavam gangues na escola, destruíam móveis e muitas vezes ameaçavam os professores ou quem estivesse no lugar de cuidador delas. As ameaças, lutas corporais e roubos eram comuns nos primeiros momentos do atendimento, quando entraram para o Núcleo, e começaram a ser atendidas pelo serviço de psicologia,

Escolas encaminhavam periodicamente relatórios sobre essas mesmas crianças e adolescentes, dizendo que estes são “casos perdidos para o tráfico”. São crianças de quem ninguém quer cuidar, com quem ninguém se importa. Como compreender o comportamento antissocial de crianças, cuja inserção no mundo do crime é real? Será que a violência tornou-se parte delas? Percebe-se que essa violência, como um objeto interno, encontra uma identificação projetiva, que é real. Mas o que é possível fazer para que essas forças não as aniquilem? O que fazer para que o cenário da violência seja modificado, e que o tráfico não seja a única opção delas? Será que instituições não governamentais, como essa na qual trabalhamos, podem constituir-se como uma saída viável para a violência sofrida por essas crianças nas comunidades, de modo a diminuir seu comportamento antissocial?

No decorrer dessa pesquisa, tivemos a oportunidade de estudar o comportamento dessas crianças e adolescentes, e buscar formas alternativas para que suas pequenas histórias pudessem encontrar razão de ser no mundo.

\section{3 \\ Como subir o Morro do Galo?}

Subir o Morro do Cantagalo todos os dias não é tarefa nada fácil, pois o núcleo ou base de atendimento da ONG do Cantagalo fica localizado exatamente na última parada da Kombi ou da moto. O prédio é de uma dimensão gigantesca, 
praticamente do tamanho de um campo de futebol e com apenas uma entrada. O quartel da UPP está instalado a uns cem metros de distância, tornando o lugar praticamente uma extensão da própria UPP.

Subindo a pé o Morro, passávamos pelas casas que estão no alto, além de do boteco da Gorda, que é dona de três casas no Morro, além do próprio bar, que é um estabelecimento com infraestrutura de restaurante, com ar condicionado, cadeiras ao ar livre e um pequeno espaço onde se encontravam máquinas de fliperama para a diversão das crianças que param no bar. Ao passar pelo bar, logo a direita havia o prédio da UPP, com cinco andares e com uma escada de mais de 50 degraus de distância da ladeira da favela. São 27 andares que separam o asfalto do alto do Morro, além de um pátio externo onde os moradores e policiais se aglomeram para estacionar seus carros.

Para entrar na favela de carro é preciso ter paciência, não só pela dificuldade que subir uma ladeira tão íngreme, como para estacionar o carro. Parece que quase todos os moradores possuem um carro. Eles ficam espalhados pelas calçadas, já muito precárias e estreitas ao longo de toda a rua principal da favela. E quando tentamos estacionar o carro no pátio, que é destinado aos professores e profissionais que trabalham nas ONGs instaladas no prédio, não conseguíamos. As vagas eram sempre preenchidas pelos moradores e pelos policiais, que paravam seus carros particulares neste local.

Mas há opções para subir o Morro: um acesso que se tornou muito comum e mais difundido pela mídia, um chamado "elevador panorâmico”, ou seja, um elevador que se encontra posicionado em uma das entradas do metrô da estação General Osório em Ipanema, de onde tínhamos uma vista da cidade do Rio de Janeiro a partir de quase seus 27 andares.

Esse elevador foi difundido principalmente pelos guias turísticos, pois foi criado com o intuito de os turistas poderem apreciar a vista do mar de Ipanema e da lagoa Rodrigo de Freitas. O elevador permite que chegássemos à metade da favela, e para entrar, era preciso caminhar pelos becos e avançar pelas imensas escadas que são utilizadas pelos moradores. Mas no meio da favela, existem casas com reboco e tijolos, mas existem outras que são apenas de madeira, deixando seu interior exposto pelas lacunas que uma madeira deixa na outra. Elas convivíam maciçamente com a possibilidade de suas casas serem destruídas pela força das 
chuvas ou mesmo serem invadidas, pois a grande maioria não tinha portas com tranca.

Já tivemos a oportunidade de presenciar um turista assustando-se com o morador que não queria que sua casa fosse fotografada, expulsando-o do local. Outros moradores não pareciam dar muita importância para as excursões de turistas. Ouviam música em volumes altíssimos e não demonstravam qualquer tipo de cordialidade para com o turista que quisesse fotografar o local. Mostravam ostensivamente aos turistas que, eles precisam entender que, ali, a ordem é estabelecida pelos moradores, que nem sempre estão dispostos a ter suas vidas expostas. Era interessante observar, como os moradores das casas de madeira, pareciam não se importar com os olhares de curiosidade de muitos turistas voltados para eles, tanto que um aceno ou um "bom dia” era comumente ouvido de dentro dessas casas.

Em uma de suas incursões ao morro, a pesquisadora se deparou com uma mãe moradora de uma das casas de madeira, brigando com seu filho pequeno e com outro no colo. Aos gritos, ela pedia que a criança se comportasse na escola e que a obedecesse, já que segundo ela, a criança já era um menino grande. A criança aparentava ter no máximo seis anos de idade. Esse tipo de cena é comum. Mesmo a observação não sendo intencional, é muito difícil não ouvir determinadas conversas, ou mesmo, presenciar situações de brigas e gritos entre os moradores, entre vizinhos ou mesmo dentro de casa com seus parentes.

Quanto mais adentrávamos a comunidade, percebíamos como era estreita a relação de convivência dos seus moradores. As pessoas conviviam como uma grande família, que se dividia em pequenos cômodos e que possuíam estreitas paredes que os separam. Gritos e brigas não foram as únicas formas de comportamento que observamos. Presenciamos também situações de amizade, de companheirismo e solidariedade que os moradores pregam com grande facilidade.

Era comum subirmos e respirarmos o cheiro do café da Tia Maura, pessoa carismática, figura constante nas dependências da ONG. Ela era muito conhecida por desfilar nos blocos carnavalescos da zona sul, sempre representando a comunidade. Era só passarmos pela porta da Tia Maura para sermos prontamente convidados para tomarmos um cafezinho com ela, o que já havia se tornado um simpático hábito. Mas quando olhavámos para o lado, sentíamos ao mesmo tempo, 
misturado com o delicioso cheiro do café, o cheiro da vala que corria por quase toda a extensão da favela e que não parava de jorrar esgoto. Era uma cena comovente assistirmos à Tia Maura trazendo de sua casa um pouco do carinho junto com seu café, e saber que aquela vala que corria a olhos vistos, não terá cessado ao sairmos da porta da casa dela. Todavia, para quem trabalha no Cantagalo e convive com seus moradores todos os dias, essa realidade passava a ser percebida como “comum”.

Não nos espantávamos, por exemplo, quando víamos um morador às seis da manhã, escutando em um volume sonoro altíssimo um funk, música bem difundida na favela, principalmente nos bailes que ocorrem todos os finais de semana.

Trabalhar na favela nos possibilitou vivenciar dificuldades que eram comuns naquele cotidiano. Nos dias de chuva, o Morro do Cantagalo ficava intransitável. Essa frase era incessantemente repetida por aqueles que subiam a favela nesses dias. Era comum entrarmos nas ruelas em dias de chuva, e nos depararmos com a lama nos becos misturada com a fossa que jorrava esgoto dia e noite. Tínhamos que nos desviar da língua de fossa que se estendia por toda a via principal. O mau cheiro era, muitas vezes, insuportável. Os becos eram invadidos por essa lama, que descia e que, dificultava a passagem de quem utilizava os próprios becos e as escadarias, muito estreitas e de alturas variadas de um degrau para o outro. Para subir a favela, era preciso ter disposição e não pensar no que a lama fazia com os sapatos.

E então, com certo esforço, a subida era conquistada e começávamos o trabalho de "malabaristas", tentando a todo tempo nos esquivarmos das pessoas com seus guarda-chuvas abertos, as poças que pareciam lagoas pelo caminho, da lama misturada ao esgoto, do lixo e dos detritos que eram deixados para trás por uma ou outra família; no momento de uma mudança; ou quando estavam chegando móveis novos em alguma casa; e os antigos móveis eram jogados fora. Precisamos aprender também a nos esquivarmos dos animais que ficam soltos na favela. Os animais que ficavam soltos eram: cachorros, galinhas e porcos, os ratos que pareciam ter o tamanho de um gato adulto e, finalmente, as baratas imensas que saíam de todos os lugares, e ficavam correndo pelos becos e entrando nas casas. 
É bom mencionar um dos animais que mais chamava atenção era um galo que ficava solto próximo à quadra de futebol, no meio do Morro. Toda vez que alguma pessoa se aproximava, o galo começava a perseguí-la, até que esta mudasse seu itinerário. Isso acontecia frequentemente com os turistas, que faziam excursões pela favela. Para os moradores era mais fácil, batiam várias vezes com o pé no chão, para o galo se assustasse e se escondesse. Mas, os desavisados levavam boas corridas do galo do Cantagalo.

O dia de chuva forte na favela era dia de tomar cuidado para não escorregar nas ruas, principalmente no “Quebra”, lugar conhecido, que ficava no centro da favela, meio que uma divisória das casas. É fácil dizer onde se mora, quando o “Quebra” é uma referência. O “Quebra” sempre ficava alagado quando estava chovendo, e também se tornava ponto de referência quando chovia muito, talvez para quantificar a intensidade da chuva do dia. Então, quando ouvíamos, “o Quebra alagou”, era um alarme de que a chuva estava torrencial, para termos cuidado ao subir pelas escadas e nem sonhar em subir de moto.

Os motos-táxis, nos dias de chuva, dirigiam suas motos como se fossem verdadeiros pilotos em uma competição. Na chuva, a maioria dos moradores não se arriscava a subir com motos e preferiam mesmo enfrentar a água que descia morro abaixo com a força de uma cachoeira; ou então subir pelos becos e escadarias. Mesmo sendo perigoso, era mais tranquilo do que subir de moto e correr o risco de sofrer um acidente.

O Cantagalo tem outro elevador, ou melhor, dois elevadores. Os elevadores do prédio, que ficam no alto do Morro, entre as ruas Farme de Amoedo e Alberto de Campos, em Ipanema. Assim, era comum nos depararmos com os dois elevadores que quase nunca estão funcionando e um espaço de terra que os alunos do CIEP utilizavam para fazer plantações. Havia um pequeno lago construído com a água das chuvas e dos canos sempre furados, quase um pequeno aquário artesanal, onde as crianças ficavam apreciando os peixinhos. Dali surge um corredor largo que dá direto para diversas ONGs. Essas faziam parte de um grupo localizado dentro do espaço do CIEP.

Subindo por esse elevador, o acesso é direto para dentro do CIEP do alto da favela. Ele costumava quebrar constantemente e não permitia que, quem viesse por ele, esbarrasse com seus moradores. Por esse acesso, entrava-se e saía-se 
da favela, sem saber o que estava acontecendo ao redor. Sem saber se havia lama nas ruelas, se a língua da fossa estava correndo entre as ruas e dificultando a passagem; mas também sem receber os acenos e sorrisos de quem descia e subia o morro todos os dias. Muitos dos professores do CIEP só conheciam esse elevador, que funcionava também como elevador de cargas, pois muitos motoristas se negavam a subir, em função de ser tão íngreme. Quando começamos a subir sem estarmos habituados com a altura do Morro, a sensação era de estarmos escalando uma montanha, e, que, a qualquer momento, poderíamos escorregar e cair.

Aliás, quedas de moradores ou de pessoas que subiam o Morro não eram raras de acontecer. Muitos moradores, principalmente os obesos e idosos, machucavam-se constantemente.

Outra maneira de subir o Cantagalo era de Kombi, mas essa só funcionava a partir das dez horas da manhã e seu valor financeiro era custoso. Para subir o Morro pagava-se a quantia de dois reais e cinquenta centavos, e para descer, um real. Além de onerosa, a Kombi só subia o Morro quando estivesse lotada. As pessoas precisavam esperar que outros moradores ocupassem todos os lugares, para poderem chegar aos seus destinos. Mas se as pessoas estivessem com pressa, e não quisessem esperar que a Kombi completasse seus seis lugares, havia a opção do moto táxi, que já foi referendado. Para muitos moradores, essa opção era considerada uma aventura.

O Morro era muito íngreme, por isso a subida de moto era perigosa. Pelo preço da Kombi, o uso de um capacete “comunitário”, (sem preocupação com a higiene de quem usava a proteção), era subir com a moto que estivesse disponível. Apesar de o trecho parecer curto, tínhamos tempo de fazer amizades e de ouvir as queixas dos moradores, sobre como eram tratados pela polícia local.

A última opção para subir o Cantagalo era indo pela estrada principal caminhando, a pé. Não era uma forma fácil, pois como já dissemos, o Morro é muito íngreme e demanda fôlego e tempo. O tempo que levava-se para subir sem parar para descansar era de exatamente 26 minutos.

Mas havendo disposição para essa subida, essa era uma das maneiras interessantes de chegarmos ao destino. Quando subíamos o Morro pela estrada principal, tínhamos que ter cuidado para desviar das motos, dos caminhões sempre cheios de areia ou material de construção, além do caminhão do lixo; que tinha 
grande dificuldade em se espremer entre os carros que ficavam estacionados; e provocavam imensos engarrafamentos. Alguns carros pareciam não terem saído do lugar por muito tempo. Tão empoeirados que pareciam jamais terem sido removidos dali.

Ao lado dos bares mais populares da favela, como o Bar da Gorda, estava o CRAS (Centro de Referencia de Assistência Social), cuja função era desconhecida para muitos dos moradores da favela. Inúmeras vezes, ao dá-lo como referência de um local que pudesse auxiliar um morador a garantir seus direitos, muitos não sabiam sequer onde ficava, e nem para que servia. Era ali também que o esgoto encontrava-se a céu aberto, do qual era muito difícil nos desviarmos. Era preciso pisar com cuidado, primeiro para que o esgoto não respingasse nas roupas e segundo, porque o contato direto com ele, podia provocar inúmeras doenças. Então era preciso conviver com essa situação da maneira mais simples: chegar ao Núcleo e lavar os pés.

Mesmo no caminho com menos escadas, às vezes encontrávamos dificuldades, como subir e não conseguir ter fôlego para continuar. Então o ideal era subir devagar, esperando que o organismo se adaptasse ao esforço que estava sendo compelido a fazer. Mas o caminho podia ficar ainda mais complicado, pois quando chovia a água também descia pela ladeira do morro como uma cachoeira. Era uma cena comum, que um morador ou um visitante, escorregasse nesse momento.

Às vezes tínhamos que subir na posição de “engatinhar” quando a chuva era muito forte e nos segurávamos onde podíamos, no próximo degrau ou nas paredes externas das casas que ali se encontram. Quando a chuva era muito forte, e precisávamos usar guarda-chuva, era recomendável segurá-lo com força, para que ele não ficasse preso entre as paredes das casas, e para também fechá-lo quase todo o percurso, pois as ruas ficam estreitas de uma forma tão intensa, que não conseguíamos deixar o guarda-chuva aberto o tempo todo. A distância de uma casa para a outra também era muito pequena. Às vezes parecia que estávamos vendo uma mesma casa, quando na realidade, eram três casas juntas. São pequenas construções que se aglomeravam, e que configuram o que é hoje o Morro do Cantagalo. 


\section{4 \\ O trabalho do Projeto Circo Social: Como tudo funciona?}

No Cantagalo, as atividades principais eram o Circo Social, hip hop ou break. Todas com instrutores especializados, gente da comunidade que nesses quinze anos de permanência da ONG na favela, foram inseridos na arte e na cultura. Havia instrutores que, a partir do que aprenderam, já viajaram pelo mundo, e agora são os multiplicadores desse aprendizado. Mostram que há possibilidades dentro da dança, da cultura, da arte e do circo de se tornarem cidadãos conhecidos pelo mundo, e não como favelados sem futuro. E principalmente conseguem o reconhecimento como artistas, que conseguiram através de seus esforços um lugar ao sol, uma oportunidade para mostrarem seu talento ao mundo.

As atividades são abertas e tínhamos alunos que vinham de bairros afastados do Núcleo. Quase todos os dias éramos visitados por personalidades da mídia, como teatro, cinema e televisão. Artistas que vinham à favela para prestigiar o trabalho dos nossos “meninos e meninas” do circo. Muitas vezes, chegando ao núcleo para mais um dia de trabalho, deparávamo-nos com Caetano Veloso ou Cléo Pires que tinham vindo conversar conosco. Era gratificante ver o quanto isso era importante para as crianças da comunidade. Cada artista que vinha prestigiar o trabalho realizado por uma criança contribuía para que ela tivesse sua autoestima estimulada e sua arte valorizada. Quem não gostaria de receber um aplauso do Caetano Veloso? Quem não ficaria feliz com os elogios de uma Fernanda Abreu? Ela e Regina Casé são madrinhas do Núcleo Cantagalo.

Esses artistas tinham como hábito visitarem constantemente o Morro e de participarem das apresentações promovidas a cada mês, onde todos os alunos apresentavam-se para a comunidade e seus familiares. Todos ficavam lisonjeados e a cada dia, muitos meninos podiam mostrar seu talento, e viver o resultado de seus esforços em apresentações com cachês.

E como fazer parte das oficinas? Essa era uma pergunta que quase todos os dias ouvíamos quando subíamos as escadarias da favela. Primeiro convidávamos as pessoas para fazerem uma visita, acompanhados de suas crianças e adolescentes. Quando elas aceitavam, a equipe tinha a incumbência de distribuir um folheto explicativo de cada oficina e a documentação necessária para que as pessoas pudessem ser inseridas como membros inscritos em nossas atividades. 
Havia uma ficha de inscrição, que tinha como objetivo: conhecer a vida das pessoas, suas metas, necessidades de trabalho, moradia, entre outras informações necessárias dos usuários, ou melhor, “os assistidos”, termo que o próprio criador da ONG usou para batizar as pessoas que faziam qualquer tipo de oficina ou que recebiam atendimento do núcleo da ONG. A partir disso, era agendada a visita de um dos membros da Equipe Técnica Social à família.

O Núcleo Social do Cantagalo, com o projeto social do Circo Social, desenvolvia, como referido anteriormente, principalmente atividades lúdicas como: brincadeiras, construção de figurinos para ornamentação dos alunos nas apresentações, fomentação das raízes culturais afrodescendentes brasileiras, atividades de aulas circenses com malabares e tecido, entre outros. Seu espaço físico era quase todo tomado por um picadeiro. As oficinas de atividades culturais do circo eram oferecidas três vezes por semana, com três turmas a cada dia. As turmas da tarde separavam os alunos por idade. A turma da manhã era composta por alunos de todas as idades. As terças e quintas-feiras eram oferecidas oficinas de Dança Popular como carimbo, maracatu e break, com uma turma apenas no turno da tarde. A idade mínima para o ingresso nas oficinas era de seis anos e não havia idade máxima, porém a maioria dos alunos das oficinas tinha entre sete e vinte e quatro anos.

O Núcleo Social do Cantagalo trabalhava com os chamados subgrupos, que em tese agregavam os alunos que sobressaíam em habilidades artísticas nas oficinas, com vistas à profissionalização deles naquela modalidade artística. Os integrantes dos subgrupos recebiam uma bolsa auxílio, cujo valor variava entre os Núcleos e entre os subgrupos. No Núcleo do Cantagalo, apenas o subgrupo do circo, o Circo Profissional, recebia a bolsa auxílio. Na época, o Circo tinha aproximadamente vinte integrantes e o valor da bolsa era de R\$150,00 em média. Até os integrantes do circo social passaram a receber ajuda financeira. Além da bolsa auxilio, havia também os cachês de apresentações em diversos locais da cidade. Desta forma, o próprio projeto promovia uma melhora financeira para os seus integrantes.

O Núcleo onde o projeto se encontrava, possuía ainda uma cozinha onde eram preparados os lanches e almoços para os alunos. Aos sábados acontecia o almoço de integração, no qual todos os alunos e funcionários sentavam-se juntos 
para almoçar e confraternizar entre si. A equipe do projeto social era composta por uma cozinheira; vários auxiliares de serviços gerais; uma recepcionista; vários agentes de projeto; além de uma equipe técnica social composta por duas psicólogas; duas assistentes sociais; uma pedagoga; os professores e instrutores de circo; e dois coordenadores.

A coordenação se dividia em artística e social. O Coordenador artístico tomava a frente das atividades artísticas das oficinas e dos subgrupos, e a outra Coordenação liderava a parte administrativa, que incluía os eventos sociais e pedagógicos que eram organizados para os alunos e os demais moradores da favela, além de administração financeira de todo o projeto social.

Importante ressaltar a seriedade e a implicação da psicologia clínica dentro da proposta do projeto. Um trabalho que teve como base fundamental a arte e a criatividade, através de atividades lúdicas e circenses realizadas com essas crianças e jovens dentro do Circo Social. Foi a partir desse trabalho, que construímos o campo referencial para a prática. A partir daí, a vida de muitas crianças e adolescentes começou a mudar. Mudança essa, que envolveu o movimento de inclusão destes em um espaço terapêutico, de cultura e arte. Além disso, criamos um ambiente onde os sofrimentos, as dores e suas vicissitudes, tiveram um lugar de escuta e acolhimento. 


\title{
3 \\ A violência de todo dia: as vicissitudes de crianças e adolescentes moradores do Cantagalo.
}

\begin{abstract}
A alegria de viver, a solidariedade, a compaixão pelos outros devem ser considerados como sentimentos em vias de desaparecer e, por isso, convém protegê-los, revivê-los, reimpulsioná-los por novos caminhos.
\end{abstract}

Félix Guattari, 1992

De acordo com a Organização Mundial de Saúde (OMS), a definição de violência é o uso de força física ou poder, em ameaça ou na prática, contra si próprio, outra pessoa ou contra um grupo ou comunidade que resulte ou possa resultar em sofrimento, morte, dano psicológico, desenvolvimento prejudicado ou privação.

Porém, os especialistas da OMS Dahlberg e Krug (2006) afirmam que o conceito de violência é muito mais amplo e ambíguo do que a mera constatação de que a violência é a imposição de dor, a agressão cometida por uma pessoa contra outra; mesmo porque a dor é um conceito muito difícil de ser definido ou ate mensurado. Podemos pensar, por exemplo, na dor física, dor emocional e dor psíquica. Os efeitos da violência no indivíduo se manifestam de várias formas.

Para todos os efeitos, guerra, fome, tortura, assassinato ou preconceito, a violência se manifesta de várias maneiras, com consequências individuais, coletivas, subjetivas, e por isso mesmo, políticas.

Na Comunidade Internacional de Direitos Humanos, a violência é compreendida como todas as violações dos direitos civis de vida, propriedade, liberdade de ir e vir, de consciência e de religiosidade. Direitos políticos, como o direito a votar e a ser votado, ter participação política e social, ter direito a habitação, saúde, educação, segurança, emprego e salários adequados, além do direito de manter e manifestar sua própria riqueza cultural.

Segundo Jurandir Freire Costa, o conceito de violência pode ser compreendido como:

uma forma de cultura, valorizando a utilização da força, construindo uma nova hierarquia moral. $\mathrm{O}$ universo social simplifica-se monstruosamente entre 
fortes e fracos. Quem ocupa a posição de agressor é objeto de temor e ódio por parte da vítima e quem ocupa a posição de vítima é objeto de desprezo e indiferença por parte do agressor. Pouco importa as características físicas, psíquicas ou sociais dos sujeitos (COSTA, 1993, p. 83-89).

No morro do Cantagalo, a violência incidia de numerosas formas. A violência vivida na favela, no entanto, não compreendia apenas os crimes perpetrados pelos traficantes ou pela polícia, mas todo o efeito que provocava sobre as pessoas e nas regras de convívio. Por exemplo, na violência urbana e estrutural, e sua interferência no tecido social, prejudicando e corroendo a qualidade das relações sociais e da vida das pessoas. Certamente o tráfico de drogas agravava esse quadro.

As formas de violência, tipificadas como violação da lei penal, como assassinato, sequestros, roubos e outros tipos de crime contra a pessoa ou contra o patrimônio, formam um conjunto que se convencionou chamar de violência urbana, porque se manifesta principalmente no espaço das grandes cidades (http://www.serasaexperian.com.br/guiacontraviolencia/violencia).

Na violência estrutural, o Estado cria maneiras de proteger as pessoas contra o que o próprio Estado produz, quando impõe regras, valores e normas, construindo-as para a população como formas naturais e necessárias ao desenvolvimento da sociedade capitalista e ao progresso, e que nunca chegam às classes menos favorecidas. Esta exploração se sustenta e se legitima por meio da ideologia, uma vez que as leis se solidificam independente da vontade e consciência dos homens, como forma de legitimar as relações de produção, segundo Neto e Moreira (1999). Assim, as normas, regras e valores capitalistas sustentam toda a forma de produção e exploração do capital, para que estas sejam camufladas e não sejam consideradas ações violentas.

O direito à vida está ameaçado nos contextos de violência estrutural aos quais se somam a violência criminal e das forças repressivas do Estado. No Brasil, uma das economias mais promissoras, e também um dos países mais desiguais do mundo, essas afirmações encontram uma trágica confirmação (...). Como pensar em garantir a vida e todos os direitos para a população mais jovem quando, nas palavras das senhoras de uma favela carioca que entrevistamos recentemente, “a vida não vale nada", "o perigo é enorme”, "todo dia penso que meu filho pode morrer”? Não é uma percepção irreal. Menos de uma semana depois dessa conversa, um menino de quinze anos da favela mais próxima colocava o lixo fora de casa quando foi atingido por um tiro na cabeça. Enquanto os moradores acusavam a polícia pelo disparo, esta negava categoricamente as acusações (ZAMORA, CANARIN, 2009, p.161-167). 
Esta violência envolve tanto o caráter econômico - da estrutura, quando o ideológico - superestrutura, uma vez que a ação violenta se dá no plano material, mas que se utiliza da ideologia para legitimá-la socialmente e torná-la imperceptível (Silva, 2009). A defesa do povo através de uma polícia arbitrária e desfigurada de seu real propósito, a falta de infraestrutura adequada, tais como postos de saúde, CRAS, CREAS, para a população moradora das favelas, dificuldade do acesso à garantia de direitos são exemplos de uma violência provinda de um Estado que aparentemente não consegue dar conta das necessidades dessa população.

O mesmo Estado não consegue dar conta do número de favelas que são criadas da noite para o dia. Todo esse cenário cria as condições para que essas famílias procurem as favelas, morros e guetos para morarem. Nas favelas, elas vão se deparar com outros tipos de violências, aquelas que não estão legitimadas pelo estado, mas que existem e se tornam legítimas dentro das comunidades, as leis do crime e do tráfico de drogas.

Os efeitos dos crimes perpetrados pelos traficantes, como outra forma de violência que assola os moradores que vivem o cotidiano da favela tornou-se “coisa comum”. A lei do mais forte é imposta pelo poder da arma, sem “dó nem piedade”, punindo fisicamente quem estiver “errado" na favela, quem tiver cometido algum ato que não seja reconhecido como desejável, pela lei do tráfico. Essa pessoa tinha que necessariamente sofrer punições, a lei tinha que ser cumprida, com todo o seu rigor e dor. Quando nos referimos à dor, é porque se esse morador da comunidade fosse homem, criança, idoso ou mulher, cometesse alguma infração, seria punido, e o único modo de punir era através do sofrimento físico. Constatar, no corpo das pessoas o sofrimento, era para o tráfico de drogas, a única forma de manter os moradores controlados, o que impossibilitava qualquer tentativa de escolha pela, comunidade. Pois "não existe poder maior do que aquele que provém do cano de uma arma”. "A forma extrema de poder resume-se em todos contra um, e a extrema forma de violência é um contra todos” (ARENDT, 1994, p. 26).

Na favela, o “dono da boca”, subjugava, através de atos punitivos, que íam desde humilhações públicas, invasão das casas, até a morte, sempre operando com a tortura e degradação do corpo, deixando o sujeito sem qualquer possibilidade 
de defesa. Essa tirania vivida pelos moradores, nem sempre era compreendida como uma verdade absoluta. Ela era contestada, fosse nas associações de moradores, nos comitês cidadãos. Muitas pessoas que tiveram seus parentes e amigos no chamado "movimento", e que foram mortos, assassinados, expulsos da favela e presos, procuravam, de alguma forma, encontrar apoio uns nos outros, em uma tentativa de resistência em buscar cuidar dos seus.

A relação dos moradores com os traficantes necessita ser compreendida não como uma relação de hierarquia aceita e não combatida. A sociedade, em sua maioria, vê o morador da favela como conivente com o tráfico, com o crime, já que aceita as leis e normas impostas por esse modelo de poderio. Porém, é preciso compreender mais de perto essas relações, vê-las em suas dimensões reais. Morar na favela para uma família, não tem como prerrogativa principal aceitar a criminalidade, mas é sempre preciso algum tipo de acordo para que seja possível sobreviver à lei da violência estabelecida pelo tráfico.

Estar na favela, é estar à mercê de certas circunstâncias, que apesar de serem erradas, terríveis e cruéis, fazem parte da vida das pessoas que ali estão, e que de alguma forma já foram incorporadas como “normais” para quem vive o seu dia a dia. Essa tentativa de compreensão ou aceitação dessa forma de vida, não assola apenas os adultos, mas principalmente e de forma marcante a vida de crianças e adolescentes, que dentro de suas fragilidades inerentes a idade e fases de desenvolvimento, buscam, todos os dias, a sobrevivência em um lugar onde a lei do mais forte é a que manda.

As crianças, em suas tentativas de sobreviver, eram muitas vezes, alvos fáceis para o traficante. Não para matá-las, mas para seduzi-las. Eles se tornavam “o meio ambiente” que as acolhia, não de uma forma amorosa, mas subjugando-as a uma dependência emocional. O “amparo” era a moeda de troca para a submissão ao tráfico.

Os moradores das comunidades do Rio de Janeiro não ficam imunes aos atos violentos dos traficantes. O pavor de que a violência invada suas casas é um dos mais comuns. A violência não dá trégua e não permite que as pessoas possam falar sobre ela. É uma lei que faz calar e que se impõe como uma barreira à qualquer mudança. Quando perguntávamos às pessoas sobre alguma experiência de violência oriunda do tráfico, elas nunca sabiam dizer quem era o autor ou quais 
haviam sido os motivos das atitudes tomadas; muito menos quem teriam sido os protagonistas que propagavam e mantinham essa violência. A Lei do Silêncio, do toque de recolher na favela e o medo de que algum "alemão" soubesse o que realmente ocorria nos becos e ruelas das casas do Morro, era velado. Ninguém podia se manifestar.

A falta de equipamentos sociais básicos, a exposição a grupos armados e à ação policial truculenta são exemplos de uma violência provinda ou consentida pelo Estado. Legitima-se, no mais das vezes, uma cultura da violência, do preconceito ou discriminação, que desqualifica moral e subjetivamente negros, pobres, moradores de favela, índios, velhos, mulheres e homossexuais, que sofrem dia a dia por suas diferenças segundo Silva (2003, 2010a, 2010b).

Segundo Machado da Silva (2008) no livro "Vidas sob cerco”, as regras e normas que são impostas no contexto de uma favela não podem ser compreendidas como sendo um substituto legítimo do Estado. É paradoxal o pensamento que a presença de traficantes tem como um de seus objetivos levar aos moradores certa assistência às suas necessidades de moradia, saúde, alimentação e proteção. Até o emprego na "boca de fumo” está ligado, segundo o autor, à proximidade que os traficantes têm dos moradores e consequentemente o fácil acesso destes aos próprios traficantes; uma forçosa convivência entre eles.

Os moradores de favelas não podem ser compreendidos como cúmplices dos bandos de traficantes, porque a convivência com eles no mesmo território produziria aproximações de diversas ordens - relações de vizinhança, parentesco, econômicas, relativas à política local, etc. - e, assim se formaria um tecido social homogêneo que sustentaria uma subcultura desviante e perigosa (MACHADO DA SILVA, 2008, p.50).

Mesmo que os traficantes tenham um vínculo profundo com a favela, e com seus moradores, ou seja, tenham nascido e sido criados nela, e que até mantivessem com alguns de seus moradores laços de amizade, não se pode dizer que essas pessoas fossem coniventes com o cenário de violência perpetrado pelo crime com suas leis. A lei imposta pelo tráfico na favela é totalmente arbitrária e punitiva diante do não cumprimento de uma “ordem” estabelecida. Lei essa, que era exercida inclusive em atos de agressões gratuitas aos moradores mais antigos, fosse por não aceitarem o que lhes era imposto, ou por simplesmente por serem consideradas pessoas indesejáveis por algum traficante da facção local. 


\section{1 \\ O poder do tráfico de drogas: Quem manda na favela?}

Morar na favela não dá status para ninguém. No entanto, morar numa favela da Zona Sul é vivido de forma especial nesse sentido; ainda mais para as crianças e adolescentes. Ser criança moradora de Copacabana, ou melhor, ser um "garoto zona sul”, implica muitas vezes ganhar dos pais: roupas caras, conforto e dinheiro. Mas uma criança que mora na favela em Copacabana, não tem como ganhar isso dos pais. Nesse local, onde o traficante é figura de autoridade, a percepção das relações se modifica. A violência para a criança moradora da zona sul é assustadora, mas para a criança favelada da zona sul passa a ser assunto banal e corriqueiro.

Podemos compreender que quase sempre há uma naturalização da violência nessas relações. A sedução exercida pelo tráfico incentiva um desejo de consumismo desenfreado, pela roupa nova, pelo brinquedo caro. É dessa forma, com promessas sedutoras, que elas são aliciadas para o mundo do crime. E como responsabilizar as crianças que tem apenas o desejo de sonhar e ganhar o que os colegas que estão tão perto possuem?

É assim que o consumismo é incentivado nas favelas. As pessoas, principalmente as crianças, começam a buscam produtos supérfluos, em função da sedução do tráfico com a ajuda das propagandas na TV. A mídia transmite cotidianamente o apelo com relação aos produtos de marca. E o tráfico proporciona a elas o que promete. E para essas crianças, o supérfulo passa a ser o essencial. Na maioria das vezes elas roubam, furtam, ou entram para o tráfico local não por necessidade e sim pelo desejo de ter tudo aquilo que elas não têm condições de adquirir. Desejo de fazer parte do outro mundo sonhado, mundo em que as outras crianças podem, e que elas, sem a “ajuda” do tráfico, não podem ter.

São essas crianças que convivem com o tráfico muitas vezes, dentro de suas próprias casas. Crianças com a vida atravessada pela violência. E, talvez por identificação às figuras masculinas fortes, elas incorporam a violência como a, marca maior de ser no mundo. Espancamentos, agressões verbais, negligência, dentre inúmeras outras formas de maus-tratos, passam a ser comuns, naturalizadas na convivência. Quando os maus-tratos são vivenciados em casa, a criança passa a 
ser facilmente seduzida pelo poder paralelo do tráfico de drogas e os "tios”, como são chamados os traficantes locais, as seduzem, colocando-se no papel de pais, que “cuidam” delas e acalentam suas dores.

Entrar para o tráfico passa a ser, além de uma opção, um motivo de “gratidão” pelo "acolhimento” sentido pelas crianças em sua "família substituta”. Essa situação pôde ser ilustrada pelo depoimento de uma criança de nove anos, moradora do Cantagalo e soldado do tráfico local: "eu gosto do tio porque ele cuida de mim, é meu pai também”. Além disso, essa “nova família” passava a cuidar da manutenção financeira de muitas famílias. As crianças que trabalhavam no tráfico eram incumbidas de funções específicas, e remuneradas por “esse trabalho”.

Quando nos referimos à manutenção das famílias com o dinheiro do tráfico, estamos nos referindo a um trabalho como outro qualquer, com salário, cargos, funções e até ascensão "profissional” (crescimento dentro do tráfico), incluindo a possibilidade de virem a ser um dos “donos da boca”. Famílias inteiras eram beneficiadas por esse trabalho. Então, para que a "pacificação" e término do dinheiro certo? Segundo Vilhena, Zamora e Bittencourt (2011), as possibilidades dessas crianças e jovens serem mortos ou ficarem feridos são reais, a possibilidade de serem apreendidos e encaminhados ao sistema socioeducativo e de sofrerem maus-tratos em outras instituições também é forte. Estar no tráfico envolve vários fatores: "o respeito" adquirido na comunidade, o acesso às mulheres e aos bens de consumo e principalmente ao "acolhimento".

Winnicott (1962) deixa claro em sua teoria a importância do ambiente acolhedor. Ambiente, no sentido dado pelo autor, é a mãe-ambiente ou a mãe suficientemente boa, mas também é todo o contexto social, grupal e histórico vivenciado pela criança. O cuidado físico sustentado pela mãe, por um lado, e pelo pai, por outro, devem ser também garantidos pelo meio social ou ambiente social em que estas crianças vivem. Os problemas ambientais podem ser encontrados tanto no seio da família quanto no meio social em que estas vivem; ou nos dois simultaneamente

Se há famílias problemas não se pode culpar inteiramente a autoridade local pelas condições da favela em que a criança é criada. O cuidado físico é afetado pela capacidade das crianças ou pais de consegui-lo e se verifica que ao redor da área a que chamamos de cuidado físico há o território complexo dos distúrbios emocionais do indivíduo, de grupos de indivíduos ou da sociedade (WINNICOTT, 1962, p. 63). 
A partir disso, atentamos para um paradoxo do que é efetivamente estar no tráfico, e principalmente em uma favela da zona sul. Não é apenas o sustento da família ou o dinheiro que mantêm essas crianças nesse trabalho, mas também o status, a notoriedade que recebem dentro da favela. Assim como a possiblidade da aproximação com as “crianças do asfalto” que, do ponto de vista delas, tem tudo, compram tudo que querem. No olhar delas, o céu é o limite para as crianças do asfalto.

Para muitas dessas crianças, manter-se na facção é uma forma de expressar para o mundo a sua "inexistência”; é uma marca que define sua identidade, que lhe dá reconhecimento público, ao custo da renuncia de sua autonomia e de sua prisão a esse universo segundo Vilhena, Zamora e Dimenstein, (2005).

Esse cenário parecia caminhar para uma mudança, quando a UPP entrou na favela. UPP é o nome dado pelo Estado, a uma possível expressão de segurança pública do Estado do Rio de Janeiro, que foi amplamente divulgado pela mídia, como um projeto do estado do Rio de Janeiro, com a finalidade principal de promover a pacificação de comunidades dominadas pelo poder paralelo do tráfico. Percebemos que os traficantes já não estão com suas armas expostas o tempo todo na favela, diariamente, noite e dia. Agora é o poder da polícia sustentada pela legitimidade do Estado, que aponta as armas, AR-15, escopetas, armamento pesado. Tudo isso com o objetivo de proteger os moradores, antes aterrorizados pelo tráfico.

Enquanto a dominante nas intervenções for a ideia de controle e poder, no subconsciente do campo de concentração, não se considerar obrigatória a participação dessas populações no traço do seu cotidiano e do seu destino, estaremos girando num círculo vicioso (RIOS, 2012, p.50).

O fim da violência e do poder do traficante. Esse era e continua sendo o lema dos policiais da UPP assim que ocuparam a favela do Cantagalo. Mas tratase do fim de que violência? Consideramos importante questionar: que poder é esse que, agora, policiais ostentam pelas ruas da favela com suas armas apontadas para os moradores? Os moradores da favela estão protegidos através da legitimidade do policial da UPP? UPP que invade suas casas à procura de drogas ilícitas, que os detém quando retornam de seus trabalhos, quando os abordam em nome da Lei, ao passarem pelas vielas da favela, para serem revistados, humilhados e violentados. 
Como Hanna Arendt (1994) afirma, o “poder” legítima também violência, invade casas, barbariza moradores, ou seja, é o domínio através da violência.

A UPP, mesmo com todo o aparato e com todo o discurso de que a pacificação seria a única maneira dos moradores e principalmente das crianças, terem suas vidas modificadas com maior respeito e cidadania, não conseguiu destituir a visão de uma polícia agressiva, que impõe na favela uma nova Ordem, uma nova Lei, que nem de longe se aproxima do que a mídia expõe como sendo um “modelo" de segurança pública. A mídia, tanto a escrita, quanto a falada, descreve as UPPS como um modelo de proteção a violência vivida nos morros.

Costa (1997) afirma que no senso comum, quando falamos em violência, falamos no uso de força, com vistas à exclusão de grupos ou indivíduos de uma dada situação de poder, que podem ou não encontrar resistência na violência dos excluídos.

O que pudemos perceber no dia a dia da favela e principalmente nos discursos de seus moradores, é que, a violência apenas mudou de mãos, principalmente a violência armada. Ao invés do traficante ostentar as armas nas ruas e vielas da favela, é a vez da polícia, da UPP, que as ostentava sem o menor pudor, e que dizia "proteger" os moradores contra a violência dos traficantes. Ostentava as armas e violentava quem ousava resistir as suas ordens legitimadas pelo Estado. A voz da favela se cala novamente. A mercê da violência, agora legitimada pelo Estado.

Em entrevista para o jornal O Globo do dia 05 de Agosto de 2013, Yvonne Bezerra de Mello, artista plástica que realizava um trabalho social com crianças que foram mortas por Policiais na calçada em frente à Igreja da Candelária, em 1993, afirma que o tráfico de drogas ilícitas continua apesar da pacificação das favelas, e que as crianças moradoras continuam assistindo a venda de entorpecentes em bocas de fumo apesar da assiduidade das denominadas UPPs.

A pacificação entra para combater gente armada, mas ela não entra para combater o tráfico de drogas. Na cabeça das crianças, continua tendo gente armada dentro das comunidades. $\mathrm{O}$ fato de ter alguém armado nas portas, seja policia, seja bandido, é a mesma coisa, porque na porta da sua casa e da minha não tem ninguém armado (...) a policia teria que entrar, mas não ficar. Teria que ser substituída por serviços. Mas essa política de ocupar e deixar a comunidade não vingou, o trafico armado volta a ocupar (O GLOBO, 2013, p.10). 
Como pode ser possível para as crianças, compreenderem a presença na favela, lugar onde nasceram, onde vivem e criam seus laços, de uma polícia, que apesar de se dizer promovedora da paz, bate em suas portas apontando armas, com atos violentos a qualquer hora do dia?

Por isto, afirmamos que é também no lugar, enquanto construção social, que os sujeitos produzem sua subjetividade. E a partir dele é possível pensar o viver, trabalhar, formar laços sociais e identificar-se com os semelhantes. É a partir de um lugar - inicialmente representado pelo círculo materno/infantil - que falamos e somos ouvidos, respeitamos e somos respeitados, sentimo-nos incluídos ou à margem segundo Vilhena e Santos (2000).

As crianças e adolescente vivenciam em suas casas, no seu morro e favela o poder do fogo cruzado. De um lado o traficante de drogas que se mantém gerenciando o morro ou favela onde elas vivem, apontando suas armas, impondo sua Lei. Por outro lado, é a polícia que adentra a favela tomando seu território, e impondo um novo modelo de violência. A violência que exclui. A UPP é implementada, e através dela, o Estado tenta retomar seu lugar perdido, invadindo a favela, construindo prédios chamados Batalhões da UPP, com até seis andares, verdadeiros monumentos. Isto tudo em nome de uma paz que não vem. Que não chega até a realidade das pessoas do morro. São os mesmos policiais que antes entravam na favela atirando a esmo, são os mesmos policiais que violavam à casa dessas crianças e adolescentes, na busca por armas de fogo, ou por traficantes possivelmente entocados ou acobertados por algum morador.

No artigo "O efeito UPP na percepção dos moradores das favelas” de Burgos, Almeida, Cavalcanti, Brum e Amoroso (2011), os autores pontuam que com a concepção de uma polícia que adentra a favela para exterminar o inimigo, para os moradores a visão dessa policia pacificadora também passa a ser questionada. O mesmo policial da UPP que sobe o morro atirando, em nome da pacificação, é o mesmo que adentrava as casas do morro, e atirando primeiro e perguntando depois.

o fato da UPP ser basicamente uma experiência policial que ainda guarda relação com a lógica da guerra, isto é, pela definição de um inimigo (os grupos de traficantes) que, como também vimos, aparece aos olhos da própria polícia como submerso em uma teia de relações interpessoais que se confundem com a sociabilidade do morador comum. Desse modo, à desconfiança da população 
da favela em face da polícia, sobrepõe-se a desconfiança da polícia em face da população da favela. Ora, nesse ambiente de desconfiança mútua, como construir um clima de diálogo e de cooperação? (BURGOS, et all, 2011, p.58).

É nesse contexto, que pudemos presenciar no dia-a-dia, marcado pela violência e pela desigualdade, que as crianças e adolescentes da favela constroem suas subjetividades. Nesse ambiente cruel, que não inspira confiança é que surge o grito de socorro Winnicott (2011), mostrado pelo comportamento antissocial das crianças. Só assim, é possível conseguir finalmente alguém que lhes ouça e lhes proteja.

Não vemos batalhões da UPPs sendo construídos na Gávea, em Ipanema, bairros considerados de classe alta do Rio de Janeiro. As UPPs são construídas nas favelas, nos morros. Se é considerada pelo Estado como um modelo de segurança pública, por quê construí-las apenas nos morros e favelas?

Para Vilhena (2003), o contexto de grande desigualdade social do Rio de Janeiro é um verdadeiro agenciador de subjetividade e não podemos deixar de lado que o lugar onde crianças vivem e estudam, ou seja, que seus territórios são fatores importantes em suas produções subjetivas. Nenhuma identidade, seja ela individual ou coletiva, pode ser construída fora de sua cultura de referência.

É importante considerar a construção das subjetividades de crianças e adolescentes em meio a todas essas ações paradoxais: tentativa de um Estado segregador em implementar a paz. Em meio à práticas arbitrárias, perpetradas tanto pelos traficantes, como pela polícia, o impacto dessas ações na constituição da subjetividade desses sujeitos é da ordem do inominável. "Os sentimentos de vergonha, de dúvida e de ódio contra si mesmo, a desvalorização dos seus e até uma identificação fantasiosa com o grupo dominante” (WACQUANT, 2005, p.11).

A favela ou o morro é visto como perigoso, é feio e ilegal, onde vivem os excluídos. Da sociedade nasce o discurso, de que esse lugar necessita da ação da polícia. É o lugar que ameaça. As crianças e adolescentes vivem na pele a exclusão por morarem onde moram, por serem quem são, o que inegavelmente constitui uma fonte de sofrimento psíquico. Esse sofrimento é visível no momento em que uma criança ou adolescente furta, se comporta agressivamente na escola, em casa ou com seus amigos. A maneira que elas encontram para responder ao que vivenciam psiquicamente e que não conseguem expor de uma outra maneira, é demonstrado 
em seus comportamentos antissociais e delinquentes.

Quando uma criança rouba o que é desejado, não é o objeto roubado, o que é desejado é a pessoa, a mãe de quem a criança tem o direito de roubar porque ela é mãe. Os sintomas antissociais são tentativas de recuperação ambiental e indicam esperança. Fracassam não por serem dirigidas de modo errado, mas porque a criança não tem consciência do que esta acontecendo. A criança antissocial necessita, portanto, de um ambiente especializado que possua um objetivo terapêutico e seja capaz de dar uma resposta fundamentada na realidade à esperança que se expressa através dos sintomas (WINNICOTT, 1964, p. 116).

O sofrimento que essas crianças e adolescentes vivem influencia diretamente suas produções subjetivas. Elas deixam de ter medo de monstros nos armários e fantasmas e explicitam o receio por elementos derivados da violência presenciada no cotidiano. A brincadeira, que deveria ocorrer num espaço de liberdade e criação simbólica, agora é vivida na realidade mais dura e cruel em Winnicott (2005).

Winnicott foi o autor que valorizou como nenhum outro, o interjogo entre as forças do meio onde o sujeito esta inserido, e o sujeito, ou seja, a importância do contexto em que o indivíduo está inserido para que o processo de desenvolvimento e amadurecimento pessoal aconteça para Winnicott (1962b).

Para Winnicott, um ambiente suficientemente bom, é o alicerce da constituição emocional do indivíduo. Quando o ambiente, por algum motivo falha, essa constituição emocional é abalada. Quanto mais pobre (pobre no sentido qualitativo!) o ambiente, em termos de cuidado e acolhimento advindos da mãe ou de quem se coloca nesse papel, mais problematizada será a constituição emocional da criança. Winnicott em sua teoria do Desenvolvimento Maturacional, não relaciona um ambiente de pobreza econômica como não acolhedor, ou não facilitador e continente, mas sim a maneira como esse ambiente é vivenciado e a qualidade dessa interação entre a criança e o seu entorno. Esses fatores é que serão determinantes. As chamadas famílias-problema existem em todas as classes sociais. Logo, não podemos responsabilizar as condições da favela onde a criança cresce, pelas perturbações do seu desenvolvimento.

Considerando a existência das chamadas "famílias-problema", não se pode culpar inteiramente a autoridade local pelas condições de favela em que a criança é criada. O cuidado físico é afetado pela capacidade das crianças ou pais de recebê-las, e se verifica que ao redor da área, a que chamamos de cuidado físico, há 
o território complexo dos distúrbios emocionais do individuo, de grupos de indivíduos ou da sociedade (WINNICOTT, 1962, p.63).

Para Arendt (1994), o domínio através da violência pura vem à baila quando o poder está em vias de ser perdido, ou seja, ao se substituir a violência pelo poder, mesmo que se alcance o que se pretende o custo a ser pago é demasiadamente caro, principalmente quando crianças e adolescentes são os atores dessa luta pelo poder.

Aonde foi parar esse poder? Nas mãos de quem? Para o Estado ou para os Traficantes? E que lugar é reservado para as crianças que participam dessa dança das cadeiras das armas e da violência, em uma disputa de quem manda mais na favela? Que comportamento esperar das crianças que agora estão sem o tênis, ou videogame que pediam e recebiam. E para quem vai à insígnia de maior violência da cidade do Rio de Janeiro? Para os traficantes ou para os policiais?

Apesar de todas as nossas considerações, a UPP é considerada um modelo de pacificação social, principalmente para a vida dos cariocas do asfalto. O que se ouve atualmente entre os moradores das ruas de Ipanema, Copacabana, e bairros de alto poder aquisitivo, é que depois da UPP, os tempos de paz voltaram. Agora, as pessoas podem supostamente sair de casa, sem medo de serem atingidas por uma bala perdida, ou por alguma troca de tiros entre bandidos e policiais. Aparentemente a sociedade carioca hoje vive seu tempo de glória como há muito não vivia. Tempos de paz. 


\section{2}

\section{A Polícia Militar do Rio de Janeiro (PMRJ): Um breve histórico}

No dia 13 de Maio de 1809, foi criada a divisão militar da guarda real de policia da corte portuguesa. Comandados por Jose Maria Rebello Vasconcelos de Souza. A guarda real de policia teve participação decisiva em vários momentos da historia do Brasil, como, por exemplo, na Independência da república, mantendo em ordem a população, coesa e fiel ate então ao príncipe Dom Pedro II, nesse momento histórico.

Em 14 de Abril de 1835, houve a criação do município neutro da corte e a guarda policial da província do Rio de Janeiro. Eram reconhecidos como tremeterras, apelido dado a força e a coragem demonstrada pelos membros da corporação, e que por diversas vezes se encontravam lado a lado em conflito com sua coirmã a guarda do município da corte, e que anos mais tarde iriam formar a atual PMERJ.

Em 1960, a capital do país foi transferida para Brasília e a cidade do Rio de Janeiro, antigo Distrito Federal, passou a ter o nome de estado da Guanabara. A instituição, que naquela cidade era denominada Polícia Militar do Distrito Federal, passou a ser chamada Polícia Militar do Estado da Guanabara (PMEG).

Na década de 1980, assume o comando da Corporação o coronel Carlos Magno Nazareth Cerqueira, oficial culto e professor defensor dos Direitos Humanos. Ele esboça a primeira tentativa de mudança dos paradigmas operacionais da Polícia Militar, buscando conduzi-la para uma visão mais democrática, apagando a formação de força repressora com que fora caracterizada ao longo de dois governos de exceção: o "Estado Novo" e os "Anos de Chumbo". Graças aos esforços do coronel Cerqueira, doutrinas e programas que hoje são corriqueiros, como o PROERD e a filosofia de Policiamento Comunitário, tornam-se lugar presente na PMERJ e espalham-se para outras Polícias Militares. (http://www.policiamilitar.rj.gov.br).

Segundo Alves (2013), a PMRJ tem a tarefa tradicional de proteger os cidadãos, reprimir a ação de pessoas que cometem crimes e manter a ordem da cidade. Apesar disso, o que assistimos todos os dias nos jornais, é o oposto ao que a instituição policial se propõe a PM esta sendo invocada para uma guerrilha nas ruas, onde o traficante de drogas é o principal alvo.

Observa-se uma polícia despreparada para lidar com o cidadão, a estrutura e os valores de uma PM austera, policiais amigos do bairro, deu vez a 
ideia não de uma polícia, mas de um exército, com soldados treinados para matar. “Dai a metáfora de guerra contra os traficantes” Moreira e Evason (2013).

A PM é organizada em batalhões e cada um desses batalhões possui seus comandantes, seu próprio território, com suas sedes e quartéis, e uma hierarquia rígida. O soldado recebe uma ordem e a cumpre sem questionar. Mas quem é o PM que sobe a favela, participa de confrontos com bandidos, que invade casas de moradores e que intimida a população? O PM que recebe uma remuneração precária, que não tem infraestrutura para trabalhar, e que recebe ordens de um comando que não pode deixar de cumprir.

O problema dos baixos salários e das práticas corruptas reflete-se no comportamento truculento de alguns policiais em comunidades pobres, como quando eles entram de modo truculento nas residências, sem mandados de busca, humilham e ameaçam moradores, pegam alimentos, “confiscam” bens que eles alegam terem sido roubados, mesmo quando os moradores podem provar que foram comprados. Ainda mais grave é a prática de venda de armas para traficantes, ou o sequestro de criminosos condicionados à soltura, a um pagamento, ou a prática de extorsão para que façam “vistas grossas” para a venda de drogas (MOREIRA, EVASON, 2013, p.195).

As pessoas temem a policia até mais do que temem um bandido. Não é raro um morador da favela, dizer que não pode denunciar qualquer arbitrariedade de policiais, pois com toda a certeza sofrerá algum tipo de represália por parte do PM denunciado. Ou seja, o melhor é se calar e se resignar. Buscar seus direitos enquanto cidadãos de direito passa a significar risco de vida.

Contudo, as atribuições constitucionais da Polícia Militar do Estado do Rio de Janeiro (PMERJ) estão previstas no $§ 5^{\circ}$ do art. 144 da Constituição Federal: “às polícias militares cabem à polícia ostensiva e a preservação da ordem pública”.

Além disso, a PMERJ também atua efetivamente:

No combate ao crime organizado, através de operações para a captura de criminosos ou apreensão de armas, drogas ou contrabando; no atendimento direto à população, ajudando no transporte de doentes, na orientação de pessoas em dificuldades, na intervenção de disputas domésticas, no encaminhamento da população carente aos órgãos responsáveis por problemas de saneamento, habitação; no policiamento especializado em áreas turísticas, estádios, grandes eventos e festas populares; no controle e orientação do trânsito, mediante convênios com as prefeituras; na fiscalização e controle da frota de veículos, em ações integradas com outros órgãos públicos; na 
preservação da flora, da fauna e do meio ambiente, através de batalhão especializado; no serviço de segurança externo das unidades prisionais e na escolta de presos de alta periculosidade; No serviço de segurança de Fóruns de Justiça em municípios de todo o Estado; no apoio aos oficiais de Justiça em situações de reintegração de posse e outras determinações judiciais com risco; na segurança de autoridades do Executivo, do Legislativo e do Judiciário e na segurança de testemunhas e sob ameaça.

(http://pt.wikipedia.org/wiki/Pol\%C3\%ADcia_Militar_do_Estado_do_Rio_de _Janeiro).

Apesar do que demonstramos por meio dos fatos relatados, de uma policia truculenta, agressiva, e tão distante do que a própria PM têm como modelo, e existem ainda policiais honestos, cumpridores de seus deveres. Mas esses vivem dentro de suas corporações como verdadeiros criminosos, pois os policiais honestos precisam entrar no “esquema” dos outros policiais. Quando não compactuam com os policiais desonestos, são alvo de perseguição dentro de seus batalhões.

São os governos que decidem que política de segurança irá ser adotada pela polícia, e através de missões, comandam com ordens diretas o que é certo e o que é errado e também, quem vive e quem morre. A reação que os policiais têm a essas ordens pode ser posta na conta de uma agressividade sem limites, já que eles entram nas favelas fortemente armados e já disparando em quem estiver pela frente. É matar ou morrer. É atirar primeiro e perguntar depois, essa é a mentalidade, mesmo instruídos a não atirar precipitadamente, a racionalidade acaba fazendo com que eles pensem de outra forma, como diz a expressão, “Melhor que sua mãe chore antes que a minha mãe” (MOREIRA, EVASON, 2013, p.198).

\section{3}

\section{Das raízes artísticas da favela à brutalidade da violência}

Foi somente nas últimas décadas, que o Estado tem se mostrado invasivo em relação a essas favelas, morros e guetos onde reside a população considerada de baixa renda. Desde o surgimento das facções do tráfico de drogas em meados dos anos 80, aparentemente o Estado não vem cumprindo com sua responsabilidade de garantir a segurança nas favelas, deixando-as à mercê dos criminosos, da intimidação das milícias ou da violência policia.

A autossuficiência na favela pode ser percebida ao nos depararmos com o gatonet, tv a cabo, lan house, dentre outros aparatos, que os moradores 
denominam como luxos vindos do “asfalto”. Um dos moradores do Cantagalo, com 22 anos, aponta que não tem mais o habito de descer para o asfalto, pois no morro há de tudo, desde lanchonetes, lojas, locais para os bailes funks, e que seus amigos e familiares estão todos no morro. Isso seria uma grande razão para não deixar a favela.

Segundo Alves (2013), as favelas atualmente tornaram-se um locam em que se estabelece um modo de vida baseado no companheirismo entre os moradores, solidariedade e principalmente um legado rico história da resistência dos quilombos no século XIX. A resistência advinda dos quilombos deixou marcas históricas nos moradores das favelas, ou como a autora denomina comunidades afrodescendentes. Estas mantém, primordialmente, suas raízes artísticas tradicionais, além de incorporar uma estética moderna como o break e o rap. Estética essa que ganhou um espaço relevante dentro das favelas. Um exemplo são as "guerras de b-boys", que costumam aglomerar dezenas de jovens provenientes de outras favelas, com o objetivo de trocar experiências desta dança.

Nesse tocante, a capoeira, luta advinda dos povos africanos, e que hoje é considerada patrimônio nacional, é outro importante movimento que passou de geração em geração, e que se mantém vivo dentro das favelas.

Na favela do Cantagalo, a capoeira é uma das expressões artísticas mais difundidas entre os jovens. No Circo Social da ONG, esta atividade foi incorporada aos treinos e às apresentações. Tornou-se um destaque em apresentações no exterior. Quando as apresentações são realizadas na favela, os moradores aplaudem de pé o capoeirista que adentra o palco e começa sua performance. A luta dos antepassados negros permanece, em forma de dança e arte.

Alves (2013) aponta que o melhor dos moradores de uma favela está no seu espírito de união, de compartilhar, promovendo com esse comportamento uma lição para o Brasil. São pessoas que apesar de residirem num local com tanta diversidade de raça e de laços regionais, com tanta violência, fatores que poderiam se tornar um empecilho para uma vida harmoniosa, conseguem mostrar um espirito de solidariedade, de companheirismo, de solicitude e alegria de viver.

Contudo, esse espírito carioca permanece encarcerado nos morros e favelas, em locais com nenhuma ou quase nenhuma infraestrutura, saneamento básico, ou seja, o básico para que um ser humano possa viver com dignidade. Os 
becos estreitos, quase sempre iluminados por fiações clandestinas, são o retrato de um lugar em que o Estado parece não reconhecer como parte da vida dos cariocas, da cidade maravilhosa que estampa cartões postais em todo o mundo. O paradoxo em que vivem os moradores das favelas cariocas é facilmente percebido quando a polícia, em nome do Estado, e de uma proteção ao povo carioca, entra nas favelas, munida de armas de fogo, disposta a exterminar quem ousar obstruir sua passagem.

O caveirão sobe a favela e ao final de sua incursão, os corpos sem vida, sejam eles de traficantes ou de algum morador que infortunadamente atravessou o caminho do projétil da arma de fogo, são arrastados para o meio da favela, como troféus de uma política de segurança pública, que veio para exterminar os bandidos e dar ao povo carioca a segurança perdida desde o aparecimento do tráfico de drogas nas favelas.

Alves (2013) faz alusão à favela que vive sob o domínio de facções criminosas, sejam elas traficantes de drogas ou policiais (milicianos), como a “senzala do século XXI” (op.cit., p.40),

Senzala, termo este africano cuja chegada ao Brasil data do século XVI, remete às barracas e aos espaços de dormitório dos escravos que vivem sob o domínio da casa-grande. Um pelourinho era erguido em frente de cada senzala. Os escravos deixavam a senzala para trabalhar nas plantações de açúcar, mas passavam o resto do seu tempo dentro delas. Se esse conceito for aplicado à favela atual, a referência sugere espaços superlotados, onde inúmeras pessoas vivem em dormitórios e comunidades voltadas para si próprias, ao mesmo tempo em que, do lado de fora, uma estrutura policial de repressão permanece pronta a intimidar, bater ou matar (ALVES, 2013, p. 38).

A polícia entra na favela, para “ocupar” ou legitimar o lugar do Estado, reprimindo pela força bruta o que é considerado apenas o cumprimento de ordens, ou seja, a PM ou o BOPE sobe o morro para prender traficantes e apreender drogas e armas, e os moradores se tornam reféns de uma polícia que existe para defendêlos enquanto cidadãos pagadores de seus impostos. Porém esses moradores são inúmeras vezes entendidos pela polícia como cúmplices dos bandidos, já que não os delatam e silenciam em meio à tentativa da polícia de manter a ordem dentro da favela.

Para a polícia, qualquer morador da favela é considerado um "bandido" em potencial. Eles são revistados a qualquer momento, em qualquer hora e lugar, assim como são contidos. Não são raras as situações constrangedoras pelas quais 
muitos moradores passam ao chegar à favela e se depararem com policiais fazendo blitz. As revistas aos moradores são feitas sempre de forma agressiva e repressiva, numa controversa política de confrontação. Todos são suspeitos até que se prove o contrário. São operações necessárias: “segundo Beltrame, o Rio chegara a um ponto em que sacrifícios eram necessários e que embora fosse difícil aceitar, vidas teriam de ser “dizimadas” para acabar com o poder de fogo dos bandidos“ (ALVES, 2013, p. 43).

Sabemos, no entanto, que os sacrifícios aos quais se refere o Secretário de Segurança, ocorrem nas favelas e morros cariocas, e que são os moradores dessas comunidades, os verdadeiros alvos de uma política de segurança. Política essa que age agredindo, humilhando e mantendo as pessoas sob o jugo de uma polícia arbitrária e desumana. O papel esperado da polícia é de para proteção, mas nesse contexto que relatamos nesse trabalho, vem sendo utilizada como verdadeira máquina de extermínio. O policial passou a ocupar o lugar do algoz nas favelas, o promovedor de injustiças, a quem os moradores temem.

Em um fórum de Segurança Pública, que ocorreu em 2008, o secretario Beltrame, chegou a dizer para uma plateia, que, “as crianças das favelas já surgem criminosas do ventre de suas mães por conta do ambiente ao redor, uma vez que nele seria tão normal ver bandidos usarem armas como pessoas se utilizarem de celulares” (sic). Tal declaração conduz a uma espécie de condenação territorial. Se você nasce na favela, logo será um bandido, pois de alguma maneira, a favela se tornou um "berçário" (Alves, 2013, p.44) de bandidos, o que justificaria o argumento do então governador Sergio Cabral ao defender a legalização do aborto como uma maneira eficaz para que mães pobres e moradoras de favelas possam interromper suas gravidezes, e assim não gerar o nascimento de prováveis criminosos, ou seja, não se tratam mais de crianças e adolescentes, filhos de pessoas com nomes e sobrenomes. São os filhos de ninguém. Ou os filhos do ventre do crime. Não importa de onde eles vêm. Não importa nem mesmo que tenham o direito de nascer

O encontro com o Outro não é mais uma possibilidade de deixar-se afetar e de permitir-se novas interações, mas uma ameaça em potencial. Nos fundamentalismos cotidianos inventa-se e recria-se o perigo e o inimigo bandido, favelado, traficante, terrorista, "menor" - para que se possa oferecer segurança e defesa. Todas as versões do "menor" assustam. Adivinha-se nesse tipo de ser, tão jovem quanto ameaçador, a perversidade precoce, a frieza com 
que planeja seus crimes, a falta de arrependimento de seus atos, a crueldade, enfim, todos os elementos que compõem o estereótipo do "irrecuperável”, do mau de nascença (MAIA, ZAMORA, VILHENA, 2007, p.336).

Diante do que o Estado sugere pela fala do governador Sérgio Cabral à violência promovida por grupos de traficantes de drogas ilícitas e bandidos, até a truculência de policiais despreparados, visivelmente desequilibrados emocionalmente, apontam-nos para a construção de uma constituição psíquica atroz e perversa de crianças e adolescentes do morro. Essas crianças e adolescentes lidam com sentimentos de hostilidade, agressividade, medo, angústia, humilhações e menos valia. Muita crueldade em seu entorno, e, claro, são consequentemente afetadas por elas.

Um adolescente da favela que se encontra em conflito com a lei, embora esteja amparado por uma Constituição Federal e suas leis complementares, representa uma parcela continuamente exposta à violação de direitos.

Os adolescentes (...) não encontram eco para a defesa dos seus direitos, pois pela condição de terem praticado um ato infracional, são desqualificados enquanto adolescentes. A segurança é entendida como a fórmula mágica de proteger a sociedade (entenda-se as pessoas e seu patrimônio) da violência produzida por desajustados sociais que precisam ser afastados do convívio social, recuperados e reincluídos. É difícil para o senso comum, juntar a ideia de segurança e cidadania. Reconhecer no agressor um cidadão parece ser um exercício difícil e, para alguns, inapropriado (VOLPI, 2010, p.09).

E como essa afetação é demonstrada por esses jovens, em seu comportamento no dia-a-dia, com seus pares e familiares? Vimos demonstrações de agressividade em casa e/ou na escola, enurese noturna e diurna, pequenos furtos, até o início de um comportamento delinquente, com roubos a mão armada e entrada na vida do tráfico de drogas. É muito claro, como o ambiente é constituinte dessa “subjetividade delinquente” que emerge na favela analisada.

Winnicott, a partir de sua teoria, demonstra o quão decisivo é o ambiente no entorno da criança e do adolescente desde o momento em que estão sendo gerados por suas mães, suas relações mãe- bebê, até a fase adulta. Ele propõe que o ambiente precisa ser suficientemente bom, para que o bebê possa se constituir como uma pessoa criativa e saudável. Uma questão que já se impõe: como as crianças da favela, não todas, pois muitas apesar de tudo têm casa, mãe, família, suporte amoroso, mas as que estão especificamente da favela do Cantagalo e que têm suas vidas atravessadas pela violência, podem transcender a todo esse arsenal 
de sofrimento e violência para se tornarem adultos saudáveis e criativos? 


\title{
A Teoria do Desenvolvimento Maturacional Infantil de Winnicott
}

\begin{abstract}
Associar o ato delinquente à pobreza e a criminalidade à carência material redunda, equivocadamente, em uma posição etnocêntrica que liga a pobreza a ilegalidade, quando não à barbárie.
\end{abstract}

Vilhena, 2007

Neste capítulo sobre a teoria de Winnicott, houve a necessidade de abordarmos apenas os conceitos relacionados ao trabalho e de trazê-los resumidos. Eles serão a base para a discussão dos casos clínicos atendidos pelo projeto do circo social, mediante o modelo de estudos dos casos múltiplos em psicanálise.

Donald W. Winnicott nasceu em 07 de Abril de 1896 na cidade de Playmouth, Inglaterra. Único filho homem e mais novo, entre duas irmãs, morou em uma fazenda na qual sua família metodista e rural vivia por anos. Seu pai era comerciante e foi prefeito desta cidade. Certa vez, Donald, ainda pequeno, em um acesso de fúria e para chamar a atenção de seu pai, que certamente pensou que iria lhe punir, quebrou o nariz de uma boneca russa de uma das irmãs. Porém seu pai, simplesmente consertou o nariz da boneca e nada fez para puní-lo. Essa foi a primeira vez que Winnicott teve a experiência do ato de restituição e reparação ${ }^{3}$.

Foi a clínica com pacientes difíceis, e com o atendimento como pediatra, aliado a sua observação da relação mãe-bebe, que constituíram seu pensamento sobre o desenvolvimento emocional. A tendência antissocial, só aparecerá depois, quando ele foi consultor do governo Londrino, que solicitou sua ajuda para resolver o problema dos delinquentes. Nesse momento, Winnicott se aliou a John Bowlby para escrever o conjunto de textos presentes no livro

\footnotetext{
${ }^{3}$ Esse episódio da quebra do nariz da boneca nos remete ao pensamento de Winnicott, no qual as crianças testam constantemente o ambiente no qual elas se encontram, esse ambiente se constitui a mãe, o pai, os irmãos, a cama, os brinquedos, o quarto, a mesa, o pé da mesa, a avó, ou qualquer coisa que passa pelas mãos da criança. A criança vai testar seu poder de destruição de um objeto e o objeto por si mesmo ele tem q tentar sobreviver às tentativas de destruição pela criança. A criança tenta destruir, quebrar, perfurar, uma boneca, um ursinho, uma bola, e ele fará isso com o objeto pessoa, seja cuidador, cuidadora, mãe ambiente que vai ser transformada em mãe objeto.
} 
“Privação e Delinquência” (2005).

Foi a partir de sua clínica, ou seja, de sua experiência na observação de bebês e o relacionamento destes com suas mães ${ }^{4}$ que ele desenvolveu a sua teoria do desenvolvimento emocional infantil. O que chamava muito a sua atenção era como a dependência ocupava um lugar importante na vida de um ser humano. Era exatamente, nessa experiência do bebê na relação com sua mãe, que o processo de maturação acontecia.

A primeira etapa de desenvolvimento refere-se à dependência absoluta, na qual a criança ainda é completamente dependente em termos de necessidades físicas e emocionais do seu primeiro ambiente acolhedor, a mãe. Aqui a mãe pode ser tanto ambiente quanto objeto. Quando ambiente, ela atenderá as necessidades corporais e emocionais do seu bebê na medida em que este sente fome, sede, tem necessidade de carinho, cuidado, afeto e é atendida por uma capacidade referida apenas à mãe, qual seja, a “preocupação materna primária” em Winnicott (1958).

Quando a mãe se coloca na posição de objeto, ela está lá através da facilitação e da criação do mundo, na medida em que ela apresenta o mundo ao infante através do seio. Assim, a mãe-objeto encontra-se à disposição do bebê para que venha ao seu encontro. Winnicott referenda então, o primeiro ambiente encontrado pelo bebê como “mãe-ambiente” e “mãe-objeto” ou ainda “mãesuficientemente-boa”. Nesta fase, encontram-se também a possibilidade de acolhimento e constituição do ambiente de confiança proporcionado pela mãe em termos de sustentação das necessidades do bebê (holding) e manejo do cuidado dispensado ao bebê (handling).

Na dependência absoluta, o bebê é extremamente dependente da mãe, não apenas no que se refere aos cuidados físicos, mas também e, especialmente, dos investimentos afetivos que a mãe, destina a ele. Para Winnicott, no início, o bebê aparece fundido com a mãe, e só posteriormente e aos poucos é que vai perceber a mãe como um objeto externo a ele.

\footnotetext{
${ }^{4}$ Quando falamos mãe, trata-se tanto da mãe biológica, mãe ambiente, seu cuidador ou cuidadora que tanto pode ser um homem como pode ser uma mulher. Ou seja, qualquer pessoa que assuma a função materna na forma conferida pela psicanálise clássica. Winnicott usa diferentes termos para falar da mesma mãe, que são: mãe devotada comum (Winnicott, 1966), mãe suficientemente boa, continente materno, o ambiente materno ou o ambiente humano, seja cuidador, cuidadora, mãe ambiente que vai ser transformada em mãe objeto.
} 
A segunda fase compreende a dependência relativa, na qual a criança não é totalmente dependente da mãe e já pode se considerar tendo um "eu”. Nesta fase, o bebê passa a distinguir entre um “eu” e um “não-eu” e envolve cinco importantes fatores que estão na verdade interligados: a falha gradual da mãe e sua adaptação como resposta ao desenvolvimento apresentado pelo bebê; o início da compreensão intelectual por parte do bebê; a apresentação resoluta e confiante do mundo pela mãe ao infante, o aumento da confiabilidade do bebê em relação à sua própria dependência e a capacidade do bebê de se identificar (ABRAM, 2000; WINNICOTT, 1945) É preciso reforçar que, nesta fase, o bebê já experimentou um ambiente acolhedor na fase anterior, portanto, qualquer falha ambiental será compreendida em termos de deprivação, ou seja, perda do ambiente acolhedor já experimentador pelo bebê.

A adaptação da mãe às necessidades do bebê vai se tornando aleatória, o que permite à criança experimentar o sentido de um inicio de afastamento do objeto mãe, ate a sua separação. O bebê estará neste momento descobrindo o mundo e a si mesmo, estará se tornando uma pessoa inteira, e não mais uma unidade com essa mãe, sendo capaz de amar e odiar. É aqui que as experiências de self e não self irão se produzir, de forma alternada, ou seja, a mãe, que desenvolve um estado de "preocupação materna primária”, fornece ao bebê condições para que a sua constituição emocional revele-se a partir do desenvolvimento da integração da personalidade. Essa integração não é automática. Está diretamente ligada a condições ambientais favoráveis que fornecem experiências afetivas suficientemente boas. É a mãe que, proporcionando um ambiente suficientemente bom, isto é, um ambiente adaptado às necessidades do bebê, capacita-o a começar a existir, a ter experiências e, a partir dessas experiências, a constituir o seu eu (self).

E finalmente a independência (rumo à independência), uma vez que tudo correu bem, dentro da normalidade, e a criança conseguiu passar por todas as etapas da dependência absoluta e da dependência relativa, sem ter vivenciado falhas no ambiente, que pudessem ter impedido um desenvolvimento saudável. Este é o momento da criança desenvolver a sua verdadeira independência, sendo capaz de viver uma existência pessoal satisfatória, numa realidade externa cada vez mais complexa. É o momento da socialização. No decorrer dessa dissertação, iremos abordar cada fase com mais detalhes, dentro do processo de desenvolvimento 
maturacional.

\section{1}

Preocupação Materna Primária (a doença de ser mãe)

Winnicott enfatiza que os cuidados amorosos da mãe, serão definitivos para um desenvolvimento saudável da criança. Ao nascer, em seus estados originários, a criança encontra-se totalmente a mercê de quem o cuida, ou seja, ele não possui uma existência própria, mas uma extrema dependência da mãe ou aquele que exerce a função de cuidador.

O amor da mãe é condição preponderante e essencial para que o lactente se desenvolva emocionalmente de maneira salutar. A provisão ambiental é a base para esse desenvolvimento. Na medida em que exista uma organização social que garanta a existência de condições satisfatórias para o indivíduo quanto à alimentação, à moradia, e saúde, relativa ao desenvolvimento do lado físico, a expressão 'provisão para a saúde’ pode significar provisão para a saúde mental. Trata-se de uma noção que está intimamente relacionada à sua crença de que o desenvolvimento emocional somente é passível de acontecer se for possível ao potencial herdado de cada criança dispor de uma provisão ambiental suficientemente boa por certo período de tempo. Um ambiente facilitador, que propicie que os impulsos inatos para o desenvolvimento sejam colocados para funcionar. Para isso acontecer, é preciso uma provisão ambiental que, de modo extremamente sutil, se adapte ativamente às necessidades variáveis do bebê que se originam do processo de maturação. Através do processo de 'preocupação materna primária', Winnicott enfatiza que uma adaptação às necessidades do bebê dessa natureza só pode ser propiciada por uma pessoa, e uma que no momento não tenha nenhuma outra preocupação e que 'esteja identificada com o lactente’ de modo a sentir e satisfazer as necessidades do mesmo, de uma maneira natural.

A preocupação materna primária, ou a devoção materna, pode ser compreendida como um estado basicamente comum a todas as mães. Porém Winnicott a considera como uma “doença normal”, onde a mãe encontra-se exageradamente sensível, principalmente nos últimos meses de gravidez e nos primeiros meses de vida de seu bebê. Esse estado equivale as suas lembranças conscientes e inconscientes infantis, que permite "sentir-se no lugar do bebê" em 
Winnicot (1945). Nesse lugar, ela se torna capaz de atender de forma incondicional as necessidades do bebê. É bom ressaltar que quando o autor se refere ao termo necessidade, ele o coloca como sendo no sentido emocional, e que a sua não satisfação provocaria danos à criança, em seu amadurecimento emocional.

Sendo assim, a mãe para corresponder a essas necessidades, precisa estar identificada com sua criança:

Winnicott descreve os cuidados maternos iniciais em termos de três funções fundamentais, que são: 1- holding (segurar), que abrange os cuidados que atendem às necessidades emocionais do lactente; 2- o handling (manipular), que se refere ao toque corporal que permite ao bebê ir formando a parceria psicossomática; e 3- a apresentação dos objetos. Apresentando os objetos que o bebê está pronto para procurar, a mãe permite ao bebê a ilusão de estar criando o mundo dos objetos, tornando real seu impulso criativo (LEJARRAGA, 2012, p. 23).

Segundo Winnicott (1996), uma mãe suficientemente boa é aquela que se adapta ativamente às necessidades de seu bebê, de modo gradativo, até ele ser capaz em lidar com o "fracasso" 5 dela. A medida que o tempo passa, o bebê vai se adaptando cada vez menos completamente, e de modo gradativo, como foi dito, vai criando a capacidade em lidar com os fracassos da mãe. Neste sentido, o bebê vai se adaptando às necessidades do ambiente, e por consequência, o ambiente vai se adaptando às suas necessidades. Ele então atravessará algumas fases no seu desenvolvimento ou processo maturacional. Segundo o autor, o ambiente é decisivo para a direção dos acontecimentos ao longo de todo o processo que a criança atravessa.

A consequência disto é que, se tudo correr bem, o bebê pode ser perturbado por uma adaptação restrita à necessidade que é continuada por muito tempo, sem que lhe seja permitida sua diminuição natural, uma vez que a adaptação exata se assemelha à magia, e o objeto que se comporta perfeitamente é ilusório. Porém, a adaptação precisa ser quase exata, pois não é possível ao bebê começar a desenvolver a capacidade de experimentar uma relação com a realidade externa ou

\footnotetext{
${ }^{5}$ A mãe fracassa a não ser esse continente que o bebê necessita que ela seja. O fracasso se refere às adaptações sucessivas da mãe que tem que atender as necessidades físicas, corporais e emocionais do seu bebê. Quando a mãe não dá o peito quando ele precisa, ou quando ela não o olha pra ele, quando ela simplesmente invade o self dele e não o deixa dormir, ou quando ela dá de mamar para ele sem que ele sinta a sensação de fome, tudo isso é constituído em termos de invasões ambientais pelo ambiente materno, ou pelo cuidador ou cuidadora.
} 
mesmo formar uma concepção dessa realidade. Para Winnicott, no início, o bebê aparece fundido com a mãe, ou seja, uma única unidade, e só posteriormente e aos poucos é que vai perceber a mãe como um objeto externo a ele. Winnicott utiliza o termo holding para designar este cuidado materno, que vai além do segurar físico do bebê. O holding materno inclui cuidados tanto esses cuidados físicos quando emocionais.

A mãe protege seu bebê, com seu holding, que no início é físico, pois é a maneira que a mãe encontra para demonstrar seu amor pelo bebê, abraçando-o. Uma mãe que desenvolve o estado de preocupação materna irá possibilitar, no início da vida do bebê um ambiente suficientemente bom, criando a capacidade de o bebê começar a existir. A proteção que advém do holding materno possibilita o bebê dar continuidade ao seu "ser bebê", a sentir-se real, fundando assim as bases de sua saúde emocional.

O bebê não quer tanto que lhe deem a alimentação correta na hora exata, como, sobretudo, ser alimentado por alguém que ama alimentar seu próprio bebê. O bebê aceita como coisas naturais a maciez das roupas ou a temperatura correta da água do banho. O que ele não pode dispensar é o prazer da mãe que acompanha o ato de vestir ou de dar banho ao seu próprio bebê. $\mathrm{O}$ prazer da mãe tem de estar presente nesses atos ou então tudo que fizer é monótono, inútil e mecânico (WINNICOTT, 1949, p.28).

Preocupação materna primária é um estágio que a mãe alcança algumas semanas antes do bebê nascer, e se constitui até próximo ao desmame. A mãe precisa entrar em estado de preocupação materna primária para ser o continente ou ambiente que o bebê precisa ter para constituição do seu self, e consequentemente do seu psiquismo. Para tanto, uma vez em estado de preocupação materna primária, ela precisa se constituir primeiro como uma mãe ambiente, ou mãe devotada comum, para depois se constituir como mãe objeto para o bebê, quando ela é sede do amor instintivo e cruel do bebê. Se por algum motivo, a mãe não desenvolver o estado de preocupação materna primária, fracassando com relação às necessidades de seu bebê, essas falhas não serão sentidas pelo bebê como falhas apenas maternas, mas provocarão ruptura na sua continuidade de ser, provocando assim situações traumáticas, e que podem ter consequências avassaladoras na constituição psíquica dele.

Na progressão da dependência absoluta até a relativa, como citado anteriormente, Winnicott (2002) definiu três etapas fundamentais na constituição 
emocional do bebê, que são a Integração, Personalização e a Realização. É importante salientar que elas ocorrem sem uma sequencia exata. Tanto que ele faz referência a essas tarefas em vários momentos de sua obra.

O autor afirma que a principal tendência do processo de amadurecimento é a integração no tempo e no espaço, dando início à descrição por essa tarefa, seguida pela do alojamento na psique do corpo e, por ultimo, pela do início do contato com a realidade segundo Dias (2012). Ressaltamos novamente, a importância de esclarecermos que essas tarefas ocorrem simultaneamente, uma não pode ser resolvida sem a outra. Essas tarefas irão permitir que o bebê caminhe na direção da integração em um self unitário. Para tal, é preciso que façamos primeiro a distinção de dois estados do bebê que estão permanentemente se alterando. Os estados excitados e os estados tranquilos. Os estados excitados e estados tranquilos referem-se ao processo da integração e da não integração.

Acrescentemos que a passagem de um estado para o outro é um movimento com o qual o indivíduo lidará por toda a sua vida. E é maneira que isso é feito no inicio de sua vida, é que dará a qualidade de como ele vivenciará essa passagem entre ambos os estados.

Nos estados excitados, Winnicott descreve-os no bebê como oriundos de duas fontes: instintualidade e motilidade. Ambas as fontes configuram a manifestação do estar vivo no bebê. A instintualidade será o campo em que a sexualidade irá se desenvolver, como um aspecto importante do processo de amadurecimento do indivíduo, ou seja, é essa impulsividade, inerente à destrutividade do início da vida, que irá constituir uma das raízes da agressividade.

O bebê é um ser não-integrado, portanto, ele não se reconhece ainda como unidade. Os impulsos instintuais tomam o bebê para ação, ou seja, exigem que ele faça algo. Ele sente fome, e ao se sentir mal por estar com fome, por exemplo, não distingue esse mal estar de um barulho vindo de uma porta batendo forte. O bebê irá buscar a solução para as sensações corporais que o afligem. Nesse momento, é o ambiente-mãe em sua identificação com seu bebê, que buscará de pronto atender suas exigências. Incluem-se aí a comunicação e a mutualidade da mãe para com o bebê. Não se trata apenas de satisfação da fome, mas sim a qualidade da relação que se dá entre o bebê e sua mãe. Essa experiência torna-se algo que fortalece o ego e favorece a coesão psicossomática do bebê. 
As tensões instintuais vão gradualmente sendo integradas e pessoalizadas. Elas se tornam consistentes e o bebê se torna cada vez mais apto a reconhecer esses impulsos como um aspecto de self vivo, e não como ambientais. Porém, Winnicott, aponta para a necessidade de que se garanta as condições propícias para que essa experiência seja real para o bebê. "É por meio da provisão ambiental que torna todo o resto possível, para, depois à medida que o amadurecimento prossegue, essa experiência vir a ser satisfatória ou frustrante (DIAS, 2012, p.172).

Então, percebe-se que "se a satisfação é encontrada no momento culminante da exigência, surge à recompensa do prazer e, também, o alívio temporário do instinto” (WINNICOTT, 1990, p.57). A satisfação incompleta, segundo o autor, ou mal sincronizada acarreta também um alívio incompleto, além de impossibilitar um período de descanso muito necessário entre as duas ondas de cobrança.

O que podemos concluir é que o indivíduo busca a satisfação, sendo movido pela urgência instintual, mas é apenas quando a mãe consegue estar adaptada a essas exigências, e então supri-las, que a experiência é considerada global.

O infante precisa sentir-se seguro, ser visto pela mãe, entrar em comunicação com ela, criar o objeto que encontra, e assim poder exercitar plenamente sua motilidade durante essa experiência. É essa mãe suficientemente boa e adaptada às exigências instintuais e motoras do seu bebê que será fundamental para que ele tenha confiança e segurança como base. Base, alicerce para que essas experiências se tornem experiências do próprio indivíduo, e não vindas do meio, e sentidas como invasoras.

A motilidade é, para o autor, outra fonte de impulsos para os estados excitados, Quando o bebê, ainda feto, se movimenta na barriga de sua mãe, esse movimento por vezes pode ser percebido por muitas mães como chutes e pontapés propositais, sendo que não o são, não há intencionalidade neles. Ao nascer, esses movimentos corporais do bebê continuam, a criança dá de encontro com alguma coisa, e com isto, o meio ambiente é constantemente descoberto e redescoberto. Isso não quer dizer que o bebê consiga perceber a existência de algo fora dele, mas é à medida que essa experiência se repete, que se inicia o aumento crescente de um certo conhecimento não mental do mundo.

A identificação primária é fundamental para todas as posteriores identificações que o bebê irá realizar ao longo de seu processo. A experiência de ser 
é a base do sentimento do self. O bebê somente poderá começar a ser a partir da estrutura total mãe-bebê. A mãe é uma parte do bebê, não existindo nada além dele. A mãe seria percebida como um objeto subjetivo. Quando a mãe não se identifica com um bebê, este não existe, não é visto, ou seja, sua experiência de ser se torna débil.

Na visão de Winnicott, a noção de apercepção, se refere à experiência subjetiva que o bebê têm da mãe, pois ele, nesse momento inicial, é a mãe, o que é a mesma coisa que dizer, em outros termos, que a mãe é um objeto subjetivo. A apercepção faz referência ao olhar criativo do mundo, oposto à percepção, que alude à relação com o ambiente como realidade objetiva. Quando a mãe não desempenha sua função especular, a percepção de mãe surge precocemente, "tomando o lugar de apercepção", e o lactente deve-se ao fato de não ser visto, sacrificando seu impulso criativo e espontâneo (LEJARRAGA, 2012, p.37).

O olhar materno traz para o bebê a confiança necessária para que ele

possa se sentir vivo e espontâneo, sem ele, o bebê não existe, não pode existir. O indivíduo precisa sentir que a vida é digna de ser vivida segundo Winnicott (1956a) e é através dessa apercepção criativa que o bebê vai tornar seu o mundo ao seu redor. 


\section{2 \\ Os processos do desenvolvimento emocional primitivo}

Para o bebê não há sentido de realidade possível - nem do corpo, nem de self e nem do que o cerca - fora de um espaço e de um tempo. Não há encontro com o objeto se não houver um mundo onde estes possam ser encontrados. O bebê vive inicialmente num mundo subjetivo, portanto é preciso que tanto o tempo quanto o espaço também sejam subjetivos. Nesse momento, este é o único mundo que o bebê consegue vivenciar.

A continuidade da presença da mãe é que vai dar sentido ao tempo no mundo subjetivo do bebê. Aos poucos este vai criando uma memória da presença dessa mãe, pois ele não sabe da existência permanente dela. No entanto, ele sente os efeitos dessa presença, e, por conseguinte, vai criando uma memória dessa presença.

Nesse momento, o bebê esta consolidando o estado de ser que emergiu do não-ser. A mãe identificada com seu bebê só se ausentará num tempo que seja suficiente para que ele consiga manter a memória da presença dela. Na repetição dessa experiência e com o passar do tempo, ele começa a ter um conhecimento do self, do ambiente e do que irá suceder, ou seja, a previsibilidade. Essas experiências reguladas, repetidas, dão ao bebê um sentido de previsibilidade. Portanto, o self unitário se constrói com um cuidado ambiental sendo assim incorporado como algo que lhe é intrínseco. A integração vai se transformando num estado cada vez mais consistente. A criança então começa a ser capaz de cuidar de si mesmo, a ter autonomia em relação ao meio que a cerca.

Ao mesmo tempo em que o sentido do tempo vai sendo adquirido pelo bebê, acontece também a experiência da espacialização. É o sentido de habitar o próprio corpo. Esse corpo não esta solto no espaço, mas está sendo seguro (holding), aconchegado pelos braços da mãe.

O corpo do bebê é sua primeira morada, a morada da psique no corpo, ou do alojamento da psique no corpo. É o sentir-se em casa. Se nesse momento da vida, o bebê se deparar com uma mãe caótica, que não reconhece suas necessidades, ou que o segura de forma abrupta, ou o deixa largado em algum lugar, ou mesmo a mãe que antes mesmo que a criança dê sinais para saciar suas necessidades, agarra o bebê e o coloca no seio de qualquer jeito para mamar, apenas 
porque pensa que o bebê precisa comer, esse bebê ficará confuso e disperso. O bebê irá se sentir ameaçado por uma invasão onde ele não estará mais familiarizado com o ambiente. Ele ficará perdido num mundo caótico e sem previsibilidade.

A etapa de personalização se dá no início da vida do bebê, tanto a psique quanto o corpo não estão reunidos, isso só ocorrerá se o processo de amadurecimento correr bem. Tanto o corpo quanto a psique estão indiferenciados no início da vida do bebê.

Aos poucos ocorrerá a diferenciação, ao mesmo tempo em que a tendência à integração age no sentido de juntá-los em uma unidade. Essa união pode não ser alcançada. Vem daí o papel fundamental da mãe ao abraçar seu bebê, segurá-lo olhando para ele, para que justamente essa coesão psicossomática aconteça da melhor maneira possível. Winnicott nos aponta que essa coesão pode ser perdida, mesmo quando temos um quadro de saúde.

É importante ressaltar, segundo Dias (2012) que a conquista da personalização está intimamente ligada ao processo de espacialização e tempo. Se os braços da mãe que segura o bebê, são cuidadosos, irão assegurar assim uma coesão psicossomática. O manusear (handling) faz parte do abraçar (holding), “ser envolvido, por todos os lados, um abraço vivo, que tem temperatura e ritmo e que faz o bebê sentir tanto o corpo da mãe como o seu próprio corpo” (op.cit., p. 200).

Dias (2012) aponta que todas as experiências que o bebê vivenciar no corpo, favorecerão a associação psicossomática e contribuirão para o sentido de "real”, de realidade de self (self) - o fato de estar vivo segundo a autora, vai ganhando consistência, peso e gravidade. A maneira como o bebê é seguro, tocado, manipulado favorecerá a coesão psicossomática, e o bebê vai se acostumando a ser visto, reconhecido, a ocupar um lugar, alcançando assim a realidade de self, em um contato efetivo com o meio que o cerca.

O bebê sente a diferença quando é seguro com cuidado ou quando não o é, quando o estado de ânimo da mãe é alterado, os batimentos do corpo da mãe são sentidos. Tudo isso irá afetá-lo. Quando o bebê é seguro por muitas pessoas, isso fará com que não consiga se familiarizar com o ambiente. A mãe é, para o seu bebê, o seu próprio corpo nesse momento. Quando as intromissões acontecem, são indubitavelmente sentidas.

O bebê ainda não é capaz, no inicio de sua vida, de saber da existência 
da realidade externa. Ainda não pode perceber os objetos que estão nele e tampouco se relacionar com eles. Separar o self dos objetos é uma conquista. A única maneira que fará o bebê iniciar o processo de sentido de realidade será propiciar a ele o único sentido que lhe é possível, que é o subjetivo. Ou seja, o bebê para entrar na realidade terá então que estabelecer a realidade subjetivamente. O estabelecimento dessa realidade subjetiva será fundamental para as posteriores conquistas do bebê (que são o sentido de real próprio a transicionalidade até chegar ao sentido da realidade externa).

A característica principal dos objetos subjetivos é a deles serem confiáveis. A mãe suficientemente boa propicia ao bebê a experiência de criar aquilo que encontra, bem como de protegê-lo de qualquer fonte de irrupção de algo imprevisível que afete sua continuidade de ser. O bebê ao encontrar o objeto subjetivo, criará o que necessita, na hora exata a sua necessidade. Ele só cria aquilo que ele encontra. E para que esse processo se dê, é preciso que o ambiente externo continuamente apresente amostras do mundo ao bebê de maneira compreensiva e adequada a capacidade maturacional dele. Ele precisa sentir confiança naquela que lhe apresenta o mundo. O sentido de real da realidade subjetiva, que será o fundamento de todos os outros, se assenta, como foi dito, na confiabilidade (DIAS, 2012 p.206).

É por habitar no mundo subjetivo que o bebê pode encontrar objetos subjetivos e nesse mundo controlar esses objetos. É um mundo mágico, onde o seio aparece no momento que ele tem fome, e desaparece quando ele está saciado. O mundo onipotente do bebê. É apenas no mundo da ilusão da onipotência que o bebê pode começar a ser. A mãe, evita com seus cuidados adequados, que o bebê se depare com um sentido de realidade para o qual ainda não está preparado. Somente quando a ilusão da onipotência é bem instalada, é que, aos poucos, irá surgir a compreensão intelectual do fato de que a existência, de que o mundo criado, não irá desaparecer.

A partir de todo o processo que foi descrito nesse texto, os estágios que o bebê passa de forma gradual da dependência absoluta pra dependência relativa ainda ocorrem nos primórdios do amadurecimento ou desenvolvimento emocional infantil. Quando nesses estágios iniciais houver um padrão de falha ambiental, corre-se o risco do desenvolvimento de patologias, tais como a psicose.

Interessante ressaltar, que ao mesmo tempo em que a mãe estimula a separação, ela evita que esta ocorra. A separação não pode de fato acontecer, pois 
implicaria ruptura traumática no processo de desenvolvimento do bebê, rumo à integração e à independência. A saúde psíquica do adulto vai depender de forma radical da qualidade, do ritmo e da intensidade com que o bebê sente esses primeiros momentos da ausência da mãe. Winnicott (1945) diz que com o ser humano não pode haver separação, mas apenas ameaça de separação; sendo que a ameaça será mais ou menos traumatizante dependendo de como foram experimentadas as primeiras separações. A separação é o tempo vivido como espera do reencontro com o objeto; a ameaça de separação é o tempo vivido como medo de não reencontrá-lo.

No estágio da desilusão, diferente dos anteriores, o bebê inicia uma gradual desadaptação da mãe. Essa desadaptação não acontece da noite para o dia. A mãe saudável, que foi suficientemente boa por todo o período da dependência absoluta do bebê, conseguirá sair do estado inicial da preocupação materna, e possibilitar pequenas falhas do ambiente e a consequente desilusão do infante onipotente. É importante ressaltar, que o bebê só poderá dar início ao processo de desilusão se a capacidade de ilusão de onipotência tiver sido bem fundada.

Na passagem da ilusão para a desilusão, a ilusão não desaparece, ao contrário, o bebê continua a sentir que o mundo foi criado por ele e que pode continuar a ser criado e não desaparecer. E com o passar do tempo, a criança saberá que o mundo sempre esteve ali e assim o será até depois de sua morte. O sujeito retém por sua vida toda a capacidade para a ilusão. É esse o momento que a criatividade se constitui. Ela se constitui no psiquismo do bebê, a partir das experiências de onipotência e da criação do mundo, na medida em que ele experimenta a ilusão. A desilusão marca a experiência do bebê em estabelecer contato com objetos não eu, da realidade compartilhada.

Nesse momento, o desmame assume uma fundamental importância no processo de desilusão. Quando não é o próprio bebê que inicia o processo de desmame, é a mãe que deve efetuá-lo. Dias (2012), aponta que a mãe precisa de sua agressividade, ou seja, contar com alguma capacidade de odiar ativa ou passiva, e que possa ser acionada quando se fizer necessário no momento do desmame e consequente desadaptação do bebê. A mãe necessita também estar em condições de enfrentar a ira ou o ódio do bebê provocado pelo processo de desadaptação. Os processos intelectuais se iniciam durante esse período de desadaptação. E serão as 
falhas do cuidado materno que impulsionarão o uso mental do bebê.

São as falhas do cuidado materno que impulsionam o uso da mente, é por meio da incipiente compreensão intelectual que as falhas do meio ambiente começam a ser levadas em conta, tornando-se compreensíveis, toleráveis e mesmo previsíveis (DIAS, 2012, p.219).

O movimento de se libertar dos braços e do colo da mãe para tomar a direção de uma área maior, mas ainda sujeita ao controle, necessita de algo para simbolizar o colo da mãe, ou seja, algo que o conforte, o que Winnicott (1947b) denomina como objetos transicionais. É no estágio da transicionalidade que o movimento do bebê de sair e se libertar do colo da mãe terá inicio. Porem a partir da confiabilidade que o meio ambiente lhe proporcionou, também manter aberta a possibilidade de um retorno do bebê. "Sair do cercado é muito excitante e muito amedrontador, mas uma vez fora, é terrível para a criança não poder voltar” (op.cit., p.55).

Para que os fenômenos de transicionalidade se dêem, é preciso que o bebê tenha vivido com sucesso a resolução das tarefas nos estágios anteriores, e são as experiências no mundo subjetivo que darão fundamento ao sentido transicional da realidade. "Se o sentido subjetivo do real não foi constituído, os fenômenos da transicionalidade não terão significado e seus benefícios não poderão ser usufruídos” (DIAS, 2012, p.223).

É vivenciando esses fenômenos que a criança começa a se relacionar com a realidade, pela via da criatividade e não da submissão. Esses fenômenos são identificados como facilitadores da passagem da realidade subjetiva concebida à objetivamente percebida. Considerado um fenômeno da vida, pois denota o modo como o sujeito se torna capaz de se relacionar com a realidade do mundo sem perder o seu sentido de existência pessoal.

Com o objeto transicional, algumas características da realidade externa do bebê são introduzidas na experiência dele. De ser o objeto, ele passa a possuir o objeto.

No período da passagem da adaptação dependência absoluta para a relativa, os objetos transicionais adquirem um status indispensável de função de amparo, por substituírem a mãe que se desadapta e desilude o bebê. É a passagem da “desmistura” tal qual Dias (2012) se refere ao falar da quebra da unidade mãe- 
bebê.

Os fenômenos transicionais tem variabilidade infinita, ou seja, estes só poderão ser definidos pelo uso que o bebê faz de certos objetos que estão ao seu alcance, tais como ursinhos, fraldas, paninhos, etc. O que irá importar nesse momento é o tipo especial de uso que o bebê é capaz de fazer com esse objeto que pertence à realidade externa. Os bebês se apegam de uma maneira vital a certos objetos, de tal maneira, que se tornam indispensáveis na hora de dormir, funcionando como defesas contra a inquietação e a angústia.

O objeto transicional representa o seio da mãe, ou a mãe como um todo, e não o seio da mãe ambiente: seio bom e seio mal. O seio da mãe ambiente nos seus estados tranquilos, permitindo assim que o bebê suporte o afastamento da mãe na hora de dormir. Dai então, a importância do reforço da presença da mãe, já que a imagem na realidade psíquica do bebê é tênue e frágil, e corre o risco de desaparecer e o objeto transicional perder a razão de ser.

Ressaltemos, que o caráter simbólico do objeto transicional vai depender da vivacidade e da confiança do objeto subjetivo, que dependerá da permanência e da vitalidade do objeto externo. Se o bebê fica afastado da mãe por um tempo demasiadamente longo, a capacidade do objeto simbólico se esvai, acaba, morre, ou seja, se o ambiente falhar com a quebra da confiança, e a deprivação for grave e prolongada, o bebê perde não somente o seio, a boca, mas a criatividade e o caminho para a percepção objetiva. "Perder o objeto transicional, pelo fracasso da mãe em fazer permanecer vivo o mundo subjetivo, resulta na descrença e na desesperança quanto a capacidade de relacionar-se com objetos: o interesse pelo objeto esmaece e o bebê não sabe nada sobre o que aconteceu” (DIAS. 2012, p.231).

O objeto transicional serve como uma ponte para o contato da psique com o mundo, porém esse contato com a realidade depende fundamentalmente da criatividade. Ela nos remete à ideia de construção do valor e do sentido da vida. O bebê, ao ter uma relação criativa com a realidade, faz com que a vida tenha valor e seja digna de ser vivida. Se as falhas ambientais ocorrem, o contato com a realidade e vivencias inerentes à realidade perdem o sentido.

Um ponto importante na teoria maturacional é que, é nesse momento que o bebê usa o objeto transicional, e também o destrói na fantasia, é que acontece a passagem da relação do objeto para o uso do objeto. Lejarraga (2012) nos aponta que o objeto destruído pelo bebê é o subjetivo, quer dizer, são os aspectos subjetivos desse objeto (mãe) que são destruídos. O bebê não apenas cria e acha o 
objeto transicional, como também o ataca, o destrói e o acha novamente. É um processo de destruição e de sobrevivência do objeto que permitirá ao bebê passar da relação ao uso do objeto como dissemos anteriormente. O objeto precisa sobreviver aos seus ataques destrutivos.

Tanto a ilusão quanto a destrutividade desempenham papel fundamental na constituição da realidade. A ilusão é a porta de entrada para o contato com a realidade e faz com que esse contato seja significativo. A destrutividade permite perceber o caráter objetivo e autônomo da realidade, saindo da pura subjetividade (LEJARRGA, 2012, p.83).

Nesse período, a criança já consegue fazer uso dos objetos percebidos como entidades autônomas, então o uso desses objetos transicionais perde o significado. E é preciso que realmente os perca, pois estes estão destinados a serem abandonados.

Lejarraga (2012) vai se referir a uma criatividade primária, já que o impulso criativo é primário e espontâneo. O bebê vai encontrar naquilo que a mãe lhe apresenta, a partir de seu gesto espontâneo, a capacidade criativa de criar aquilo que encontra, mas isso só acontece, se tivermos uma mãe identificada com seu bebê. O bebê que cria o seio nada sabe da existência do mundo real externo e se ilude acreditando que o mundo que existe lá fora, corresponde a sua capacidade de criar. Desconhece que a mãe-ambiente está lá superpondo objetos da realidade que coincidem com sua criação (op.cit., p.77).

O primeiro contato com a realidade, que no inicio era subjetiva, é a ilusão de ter criado essa realidade. A mãe ambiente vai desiludindo o bebê. Não para que o gesto espontâneo seja frustrado, mas para que uma vez tendo sido iludido e tenha vivenciado essa ilusão de forma plena e saudável, com a ajuda da mãe-ambiente, o bebê possa ter melhores condições de se desiludir e de reconhecer a existência de um mundo fora dele. Nesse mundo, ele poderá desenvolver as experiências de transicionalidade e ampliar cada vez mais sua criatividade. Se ao contrário disso, a criatividade for sufocada pelo meio ambiente, a criança terá sérias dificuldades em estabelecer relações significativas com o mundo, fechando-se em si própria, criando um mundo só dela, o que podemos encontrar, por exemplo, nos quadros clínicos do autismo.

Para Winnicott, o brincar é essencial na manifestação da criatividade do sujeito, e é somente sendo criativo que o indivíduo descobre seu eu, self. 
Experimenta-se a vida na área dos fenômenos transicionais, onde o sujeito passa de uma realidade da subjetividade e da observação objetiva para uma área intermediária entre a realidade interna e a realidade compartilhada do mundo externo aos indivíduos.

A confiança é a base para que essa área intermediária possa ser experimentada. O brincar criativo, o uso dos símbolos, o contato significativo com outras pessoas e toda a vida cultural do indivíduo.

O autor definiu a experiência cultural como uma ampliação no adulto da ideia dos fenômenos transicionais e da brincadeira. A experiência cultural localiza-se no espaço potencial, existente entre o indivíduo e o meio ambiente. Portanto, a experiência criativa começa com o viver criativo, que se manifesta primeiramente na brincadeira. Em um lugar intermediário, que Winnicott determinou como espaço potencial.

Para a discussão dos casos, é importante ainda que assinalemos a importância do conceito de regressão no ambiente terapêutico.

Segundo Winnicott, a regressão tem o objetivo de reformular experiências precoces do sujeito. Ela se manifesta em termos de retorno à dependência, ou seja, o sujeito em virtude de uma falha ambiental nos primeiros momentos do seu desenvolvimento, não conquistou a maturidade emocional normal a qualquer ser humano. É bom que ressaltemos que a capacidade do sujeito confiar no terapeuta e este fazer jus a essa confiança será a base para que o processo de regressão atinja seu objetivo, pois esta tem uma qualidade curativa.

Para o autor, “o retorno da regressão depende da reconquista da independência, e se isto é bem trabalhado pelo terapeuta, a consequência é que a pessoa se encontrará numa situação melhor do que antes do episódio” (LEJARRAGA,1990, p.163). Trata-se de uma forma de reviver o trauma que não foi experimentado no momento exato da falha ambiental, "possibilitando o aparecimento no sujeito do movimento de busca do verdadeiro self, intrínseco ao processo de cura” (WINNICOTT, 1956b, p. 377).

O autor pontua com bastante ênfase, que não pode existir no fenômeno da regressão, uma simples reversão do progresso. Para que isso ocorra, ou seja, para que esse processo seja revertido, é preciso que haja no sujeito uma organização que permita que a regressão ocorra. Winnicott nos aponta a necessidade de que haja 
uma organização interna no sujeito, para que seja possível o uso da regressão. Segundo o autor, é necessário que:

Uma falha na adaptação por parte do ambiente resulta então no desenvolvimento de um falso eu, A crença numa possibilidade de correção da falha original, representada por uma capacidade latente de regredir, o que implica numa organização egóica complexa. Uma provisão ambiental especializada, seguida por uma regressão propriamente dita. Um novo desenvolvimento emocional, com as complicações que serão discutidas adiante (WINNICOTT, 1945, p. 377-378).

É como se houvesse uma expectativa que novas condições ambientais surjam, oferecendo uma nova chance para que o sujeito seja capaz de defender o eu das falhas ambientais.

É preciso incluir na teoria do desenvolvimento de um ser humano a ideia de que é normal e saudável que o indivíduo seja capaz de defender o eu contra falhas ambientais específicas através do congelamento da situação da falha. Ao mesmo tempo há uma concepção inconsciente (que pode transforma-se numa esperança consciente) de que em algum momento futuro haverá oportunidade para uma nova experiência, na qual a situação da falha poderá ser descongelada e revivida, com o indivíduo num estado de regressão dentro de um ambiente capaz de prover a adaptação adequada. A teoria aqui proposta é a da regressão como parte de um processo de cura, na verdade como fenômeno normal que pode ser produtivamente estudado em pessoas saudáveis (WINNICOTT, 1956b, p. 378).

É justamente no 'congelamento da situação da falha', que encontramos a esperança de que haverá uma chance, em função de uma nova provisão ambiental, de efetuar o necessário descongelamento, propiciando a retomada do desenvolvimento no ponto em que ele havia sido detido. Dessa forma, a sustentação do sujeito em terapia deriva da capacidade do analista ir ao encontro das suas necessidades. Winnicott (1990) aponta que uma regressão que ocorre dentro de um processo terapêutico possibilita que o paciente em algum momento se revele capaz de alcançar "uma não consciência do cuidado ambiental e da dependência, o que significa que o terapeuta está dando uma adaptação suficientemente boa à necessidade” (op.cit., , p.163-164).

Para Winnicott (1990), “toda vez que compreendemos profundamente um paciente, e o mostramos através de uma interpretação correta e feita no momento certo, estamos de fato sustentando o paciente, e participando de um relacionamento no qual ele se encontra até certo ponto regredido ou dependente” (op.cit., p.353). A regressão permite que os fenômenos relativos às falhas 
ambientais possam ser experimentados e uma nova maneira, com uma nova perspectiva, resultando na possibilidade de uma retomada do desenvolvimento maturacional, no ponto em que este se encontrava congelado.

\section{3}

\section{As raízes da agressividade}

Em 1939, Winnicott foi chamado para trabalhar como consultor psiquiátrico do governo inglês, atendendo crianças separadas das famílias durante os bombardeios oriundos da Segunda Guerra Mundial. Ao final da guerra, foi nomeado diretor do departamento de infantil do Instituto Psicanalítico da Sociedade Britânica de Psicanálise, cargo que manteve por 25 anos.

Esta experiência da guerra teve um efeito profundo em Winnicott (1967), pois teve que enfrentar a confusão gerada pela desintegração maciça da vida familiar e também que vivenciar o efeito da separação e da perda - da destruição e da morte. Durante este trabalho, teve a oportunidade de trabalhar com crianças denominadas difíceis. Acompanhou profundamente 285 crianças, tendo sido a maioria delas observada num período de vários anos. Tratava-se de uma experiência com crianças evacuadas de seus lares em Londres, sob um intenso bombardeio e enviadas para o interior da Inglaterra (op.cit., p. 35). Durante todo esse percurso, Winnicott formulou teorias importantes para a psicanálise infantil, entre elas, a da tendência antissocial, a deprivação, a privação e o comportamento delinquente.

Para Winnicott, a agressividade é compreendida como parte da expressão primitiva do amor, ou seja, ela é indissociável do amor. Ele a considera inerente à natureza humana, desempenhando um papel fundamental no estabelecimento do contato do bebê com a realidade externa; tanto na distinção entre o eu e o não eu, bem como no reconhecimento do outro como distinto dele próprio. Para o autor, a agressividade está sujeita à várias vicissitudes: a proporção em que o bebê cresce, ela será vivenciada através de processos totalmente dependentes do tipo de ambiente em que o bebê vive.

Para o autor, os impulsos amorosos primitivos, ou "amor boca" (WINNICOTT, 1957, p.97), possuem em sua essência a agressividade e a destrutividade. O amor boca é um amor instintivo no qual apetite e excitação não 
se diferenciam. “O bebê sem estados excitados, é tomado então pela tensão instintual que exige a qualquer custo urgência na satisfação. Como a mãe está ali disponível e suficientemente bem adaptada às exigências de seu bebê, oferece-se para ser consumida, devorada” (LEJARRGA, 2012, p.46). O bebê então, para saciar seu impulso, vai ao encontro da mãe com violência, atacando-a vorazmente.

Esses impulsos vorazes do bebê podem ser sentidos pela mãe como cruéis e dolorosos, já que o bebê morde o seu seio, chuta (através da motilidade), como se quisesse realmente agredí-la. Porém isso não acontece. Não há no bebê uma intenção agressiva, isso seria atribuir ao bebê algo que ainda não foi desenvolvido nele. O bebê que se encontra no estágio de pré-concernimento, não possui noção do dano que pode causar a sua mãe, e nem mesmo sabe da existência dessa mãe separada dele. Nesse momento, não há culpa nem intencionalidade em ser cruel com quem ele ama. Ele não se sente responsável por seus atos, tampouco sente culpa e concernimento.

Winnicott (1958), afirma que os impulsos de amor primitivo tem um aspecto destrutivo, mas não há na criança a intenção de destruir. É importante que façamos a distinção entre o amor primitivo e a tensão primitiva. No amor, são formas de gestos e contatos, que possibilitam o bebê obter a satisfação, assim como poder expressar o alívio da tensão instintiva. Na tensão instintiva, o bebê busca a satisfação que precisa ser saciada a qualquer preço. É importante ressaltar que a qualidade destrutiva do impulso instintivo não tem a ver com sentimentos de ódio e nem da raiva que é oriunda dos sentimentos de frustração do bebê no encontro com o meio ambiente. Quando tomado por seu impulso excitado, o bebê irá amar a mãe com um “amor boca”, o amor que devora, consome e machuca. O bebê literalmente canibaliza a mãe, e nesse movimento de comer e devorar a mãe, o amor não pode ser diferenciado da destruição, que, para ele, nesse momento, são a mesma coisa.

A agressividade cria o mundo, e que também cria a destrutividade, não pode ser categorizada como saúde e doença e, sim, como um deslizar entre saúde e doença. A agressividade que destrói, destrói dependendo dos olhos de quem a vê. Assim como a agressividade que cria, cria também dependendo do olhar de quem vê criação naquilo que seria somente um movimento a esmo de um bebê. De um descobrir e não descobrir o mundo surge o bebê-sujeito, rumo à individuação, desde que o objeto sobreviva a seus ataques. 
Do contrário, a história deste bebê não será por este caminho e sim por outro, no qual a agressividade se tornará, sim, destrutividade; um testar constante à sua existência e à existência do mundo, ameaça ao seu sentimento de ser e existir como pessoa total no mundo (VILHENA, MAIA, 2002, p.42).

A motilidade é compreendida como uma das raízes da agressividade. Quando o feto se movimenta na barriga de sua mãe, esse movimento é sentido por muitas mães como chutes e pontapés propositais, sendo que não são, porque não há intencionalidade neles. Ao nascer, esses movimentos corporais do bebê continuam. Nesse processo, a criança encontra obstáculos, e, nesse sentido, o meio ambiente é constantemente descoberto e redescoberto. Isso não quer dizer que o bebê já consiga perceber a existência de algo fora dele, mas, à medida que essa experiência é repetida, o bebê começará a experimentar o aumento crescente de um conhecimento não mental do mundo.

Se tudo ocorrer bem, e o bebê encontrar um ambiente que o permita ser livremente, sem intromissões, no qual sua vivacidade se expresse através dos movimentos que acompanham a excitação juntamente com a voracidade instintual, a motilidade vai se fundindo aos poucos à tensão instintual. Essa situação favorecerá a elaboração imaginativa das funções corpóreas e é dessa forma, que a tarefa da psique se alojar no corpo é construída.

É preciso que fique claro que o movimento precisa partir do bebê em relação ao meio que o cerca. Quando isso acontece na direção inversa, ou seja, se o meio ambiente tiver a iniciativa antes mesmo da sinalização do próprio bebê, teremos um bebê com o sentimento de invasão pertencente ao self verdadeiro, que tem que encontrar um ambiente humano propício para se desenvolver, e a motilidade passará a ser experimentada como uma reação a essa invasão. Nos casos em que esse processo se repete, vira uma constante, teremos um indivíduo doente. Portanto, o que é determinante do que será ou não sentido pelo bebê como invasão, é a relação dele com sua mãe ambiente.

O bebê então, começa a erguer defesas organizadas contra as invasões ambientais, e com isso, ele passa a ter uma relação com falso self, já que este é uma proteção ou defesa organizada contra as invasões do self e do núcleo do self. Essa oposição é o que dará sentido ao seu movimento, e, ele só abrirá mão dele, quando algo se opuser à sua oposição. Quando os impulsos são experimentados apenas como reação à invasão, o self não consegue se estabelecer. Na ausência da 
impulsividade pessoal, as experiências primitivas de integração do self, próprias dos estados excitados, não acontecem.

Winnicott denomina de voracidade teórica a impulsividade "agressiva" que alguns bebês costumam apresentar no momento que são colocados para mamar no seio de suas mães. É bom ressaltar, que ele não está se referindo aqui a ideia de que o bebê esteja tentando ferir a mãe. Mas, é na urgência do alivio da tensão instintual, com a participação da motilidade, que a gengiva do bebê pode machucar o seio da mãe. A criança ainda não está amadurecido para que a agressividade ganhe sentido.

A agressividade só irá fazer um sentido quando houver um propósito, ou seja, quando for intencional. O infante, nesse momento, ainda não tem a capacidade para ter intenções. O que temos na realidade é a espontaneidade, e não a agressão. O que pode ser denominado como agressividade, nada mais do que a evidência de vida, já que o objetivo do bebê é a satisfação, melhor dizendo, a experiência de se acalmar diante dessa aflição instintual.

Winnicott (1945) nos mostra a existência de uma destruição que é inerente ao impulso amoroso primitivo. Nesse momento ele introduz o conceito de compadecimento (concernimento), que nos auxiliará na compreensão da agressividade e da destrutividade. O infante no início de sua vida, desconhece a existência do self, do ambiente, e, portanto, não possui qualquer tipo de compadecimento em relação às consequências de seu amor excitado. Embora haja um aspecto destrutivo no impulso amoroso, não existe intenção alguma doa criança em destruir.

O ambiente nesse momento interfere de modo crucial no modo como a agressividade, que se encontra em um crescente processo, será ou não integrada à personalidade total do bebê. Como estamos nos referindo aos estágios iniciais da vida do bebê, ele está inteiramente dependente da maneira como a mãe recebe as manifestações decorrentes do fato dele estar vivo. Ou seja, tudo vai depender de como a mãe responderá ao seu gesto espontâneo. A mãe, em alguns momentos, poderá reagir a esse gesto de uma maneira brusca, ou achando que o bebê mordeu seu seio porque queria lhe machucar. Isto acontece principalmente nos casos onde a mãe encontra-se doente, por exemplo, com depressão pós-parto ou desvitalizada. Quando o bebê então busca a mamada, a mãe, a partir desses fatores citados, poderá 
se retrair. O bebê para satisfazer seus impulsos, e, estando com muita fome, poderá obstinar-se ainda mais ao seio para não o deixar escapar. Nessa situação, o bebê se vê a frente a algumas alternativas, que são: 1- esconder seus impulsos (espontaneidade e vivacidade); 2-inibir a impulsividade instintual e desenvolver um autocontrole defensivo; 3- e desenvolver a tendência antissocial.

Se ao invés de voracidade, aparecer avidez (greedness), então já não se trata mais de manifestação de vitalidade. A avidez é uma espécie de crueldade (ruthless), que vem acompanhada de sofrimento, e parece insaciável. "Neste caso é preciso supor que a criança esta sofrendo algum grau de de-privação (deprivation)” (DIAS, 2012, p.180). A avidez quando não atendida pode apresentar-se de várias maneiras, inclusive como destrutividade excessiva, tornando-se então já uma manifestação de tendência antissocial.

A de-privação que transparece na avidez, mesmo estando referida à amamentação, não diz respeito às necessidades instintuais, mas às necessidades do ego. É, portanto, o papel da mãe não apenas suprir as necessidades do bebê em relação aos seus impulsos de fome, sede, mas sim, de ser para ele, um condutor adequado e adaptado tendo como base a comunicação, a intimidade e a mutualidade entre ambos, para que assim, o bebê possa realizar sua experiência instintual com sucesso.

A mãe não pode sucumbir à destruição, pois assim a criança não tem como experimentar e fazer a passagem da subjetivação para a objetivação. A mãe suficientemente boa irá ajudar o bebê para que a passagem ocorra gradualmente, sem mudanças externas bruscas, tais como barulhos fortes, e até mesmo mudanças de lugar do berço. Essa manutenção do ambiente sem modificações, esses cuidados protetivos com relação ao espaço/tempo, e a ausência de mudanças imprevisíveis para o bebê, o ajudam a manter a familiarização necessária para a continuidade do seu eu.

Segundo Dias (2012), quando a criança sente-se protegida, ela estará, portanto livre para brincar de maneira que possa experimentar tudo que se encontra em sua realidade psíquica. A destrutividade adquire então um valor positivo na criação da realidade para a criança. No estágio do “eu sou” é uma conquista do desenvolvimento emocional ou processo maturacional. A destrutividade, uma vez experimentada pelo bebê durante a fase da dependência absoluta, pode ser usada 
para defesas em um momento posterior. O bebê precisa tentar destruir a mãe, e a mãe precisa sobreviver aos ataques sádicos e cruéis do bebê, para que ele possa uma vez alcançado o estágio de concernimento, vivenciar a culpa de atacar um objeto amado e desejado e odiado ao mesmo tempo, para que ele, o bebê possa fazer reparação ao objeto que é o seio danificado pela sua voracidade instintual. Só assim, a mãe sai da condição de mãe ambiente para mãe objeto. E uma vez que o bebê experimenta isso uma série de vezes, ele pode aprender a usar a sua agressividade com uma intencionalidade, e transformá-la em agressão, com os objetos externos da realidade compartilhada. A criança irá conquistar a passagem da unidade para um eu integrado. É o resultado do longo processo de integração, que teve seu início no self primitivo e não integrado.

O infante, no estágio do uso do objeto, finalmente se separa do ambiente, depois de ter expulsado repetidas vezes, a mãe para fora do ambiente de onipotência. Dessa forma, ele consegue se separar dela. Mas para que essa separação aconteça sem danos, é preciso que a criança tenha tempo necessário para explorar esse novo estágio por completo. E é fundamental poder retornar e regredir aos estágios passados; só assim ela terá a segurança de que pode explorar o mundo objetivo. Porque sabe que poderá retornar às suas origens quando necessitar. Ela terá a certeza de que o mundo subjetivo ainda estará lá, e continuará sendo para ele uma fonte de riqueza pessoal e de singularidade.

Uma das coisas mais importantes que ocorrem neste estágio consiste em que a criança começa a perceber não só que ela é uma única e mesma pessoa quer esteja excitada quer esteja tranquila, como também que a mãe que a cuida, trocando-a, mimando-a nos estados tranquilos, é a mesma pessoa que ela vivamente ataca durante os estados excitados (DIAS, 2012, p.248).

Para a criança, a mãe vinha sendo tanto a mãe ambiente, carinhosa, amada quanto à mãe objeto, danificada e destruída. Nesse estágio, a criança está se unindo em uma só, em uma única para a mãe, e a mãe real precisa cuidar do bebê, mantendo o ambiente seguro e confiável, para que este possa vivenciar plenamente suas experiências.

Segundo Winnicott (1962a), a mãe objeto tem que sobreviver aos episódios guiados pelos instintos, que adquiriram agora toda a força das fantasias de sadismo oral e outros resultados da fusão. À mãe ambiente cabe uma função 
especial de se manter empática, amorosa em relação ao seu bebê, permanecendo pronta para receber o gesto espontâneo dele, não desapontá-lo, e ao mesmo tempo, ser agradada por ele.

A mãe, portanto, continua a ser elemento fundamental durante a resolução desse estágio, com sua presença contínua, sobrevivendo aos ataques do bebê, sempre viva e disponível. Mas sobreviver não é ficar indiferente ou imune ao que se passa; não significa permissividade. A criança sabe, agora, que esta machucando ou ferindo quando está excitada; ela sabe e precisa que a mãe também saiba. Esta não finge que "não foi nada"; não se faz de mártir que suporta o ataque porque afinal esse é o seu lugar de mãe. Não: se ela está viva, ela sente e se defende, sem tensão, sem temores acerca da natureza cruel do filho, sem reatualizar ali velhas histórias de violência sofridas. Sobreviver significa, portanto, que a mãe não desista de exercer o seu papel de no processo de desilusão: ela suporta ser odiada (DIAS, 2012, p. 250-251).

Nesse momento, a criança se depara com o medo de que os estragos que direcionou ao objeto sejam sem retorno. É necessário que a mãe forneça a oportunidade para que o "circulo benigno" (o machucar-e-remendar) possa se repetir inúmeras vezes e a criança assim acreditar na possibilidade de reparação do objeto. Portanto, o meio precisa oferecer boas condições para que esse bebê suporte a culpa gerada pela possibilidade de destruir irreversivelmente o objeto. É necessário que o círculo benigno seja incessantemente reforçado. O comportamento de reparação pode ser visto em pequenos atos que a criança expressa, tais como num gesto de um sorriso, num pedido de desculpas, provindos de seu sentimento de culpa. Quando isso não acontece, temos uma criança que não desenvolve o sentimento de culpa, não repara e não consegue entrar o círculo benigno.

Quando a criança não sentir a culpa de destruir o objeto, não conseguirá estabelecer a tentativa de reparar a ação do objeto. Isso é consequência de alguma falha ocorrida no ambiente, e, sendo assim, a criança não consegue entrar no círculo benigno. Portanto sem culpa, ele não poderá buscar a reparação do objeto. Quando o sentimento de culpa não é sentido pelo bebê, o objeto destruído não poderá ser reconstruído. Algo no comportamento da mãe ambiente falhou no momento da provisão necessária.

\section{4}

\section{A Tendência Antissocial}

Segundo Winnicott (1956b), a tendência antissocial não deve ser 
compreendida como um diagnóstico, ela pode ser encontrada em qualquer pessoa, seja ela dita normal ou não, neurótica ou psicótica. Ou seja, ele não a compara diretamente a outros diagnósticos de patologias que um individuo possa apresentar.

A base da tendência anti-social resulta de uma experiência inicial boa que foi perdida e o aspecto essencial desta é a criança ter alcançado a capacidade de perceber que a causa do desastre foi devida a uma falha do ambiente. Isso provoca a distorção da personalidade e o impulso de buscar a cura numa nova provisão ambiental. A esse processo de desapossamento, Winnicott (1964) denominará de-privação, e marcará a diferença entre essa situação e a de privação, ou seja, uma situação na qual a criança nunca teve nada, e por isso não perde coisa alguma mais tarde, diferente da situação das crianças que estamos chamando de antissociais (MAIA, ZAMORA, VILHENA, BITTENCOURT, 2007, p.336).

A tendência antissocial é uma expressão vinculada à de-privação vivida durante a dependência relativa, ou seja, trata-se uma falha ambiental em termos da continuidade dos cuidados à criança desde a sua fase da dependência absoluta. Nesta fase, a criança já experimentou um ambiente acolhedor pela mãe ou cuidadora. O ato antissocial ou o comportamento antissocial (roubo, enurese noturna, violência e delinquência) constitui-se como um imperativo relativo à falha ambiental vivida no período da dependência relativa e é um pedido de socorro que a criança faz em termos comportamentais. Ele é compreendido pelo autor como um sinal de esperança de que o indivíduo venha a redescobrir aquela experiência boa vivida na dependência absoluta e que foi perdida na dependência relativa.

Uma criança torna-se de-privada quando é destituída de algum aspecto essencial de sua vida familiar. Nesses casos, algumas situações que poderíamos chamar de complexo de deprivação, começam a se manifestar. O comportamento antissocial aparece em casa ou num contexto mais amplo.

Para Winnicott, esta é a expressão da esperança que algumas crianças ainda mantêm dentro de si, uma crença ou crédito da criança no meio, entendendose essa esperança como um movimento vindo do meio em relação à criança, curando-a de sua de-privação. De acordo com Bogomoletz (2008), a de-privação é considerada como “a perda abrupta de algo que era sentido como bom. Por contraste, o que Bogomoletz chama de 'privação' refere-se a uma situação em que a falha do ambiente era constante e começou bem mais cedo. Como a onipotência está ainda em pleno vigor, a falha é sentida como sendo do próprio bebê. 
Bogomoletz propõe que, na de-privação, não é o ambiente que deixa de ser acolhedor ou que seja sentido como ameaçador para o bebê. O que vem a ser importante para ele, é que esse ambiente vai falhar ao revelar-se destrutível; ressaltando a destrutibilidade sempre observada do ponto de vista do próprio bebê. É o momento em que de alguma forma, um dos cuidadores importantes desaparecem. Segundo ele, a criança entra num estado em que não recebe, por um tempo prolongado demais, os cuidados de que precisa, deixando assim de receber as respostas emocionais necessárias. Não houve a falta, houve a não falta, a demora demasiada.

A de-privação ocorre geralmente entre cerca de um ano e os quatro, cinco anos de idade. Segundo Vilhena e Maia (2002), Winnicott vê neste tipo de ato, a busca de um limite e de um acolhimento, demonstrado neste endereçamento, expresso pelo comportamento antissocial. Portanto, quando falamos de comportamento antissocial que não foi tratado, com a possiblidade da esperança e criatividade, Winnicott (2005) em "Privação e Delinquência” foi enfático quanto à importância do lar suficientemente bom na constituição do sujeito e, sublinha sempre que essa falha terá a delinquência como consequência no comportamento nas crianças e adolescentes.

Winnicott (1945) enfatiza que mesmo que essas crianças consigam reviver o momento de desapossamento, para a criança antissocial, fica sempre um resto com o qual ela terá de lidar ao longo de sua vida.

Em que momento as crianças e adolescentes que vivem a turbulência de conviver com a violência na porta de suas casas, se transformam em coadjuvantes dessa mesma violência? Passam a ser os delinquentes de quem as pessoas na favela sentem medo, repúdio e também certo sentimento paradoxal de compaixão. Ser um delinquente, lamentavelmente, pode ser considerado como lugar comum para essas crianças. O sentimento de desamparo que expressam é demonstrado em seu comportamento, ao ficarem nas ruas pedindo dinheiro, ou no tráfico servindo de soldados, com atitudes agressivas, antissociais e delinquentes. Há perguntas que nos povoam a alma ao pensar sobre isso: quem cuida dessas crianças? Quem se importa com elas? Será que poderemos “curá-las” desse comportamento?

\section{5}




\section{A Delinquência como sinal de Esperança.}

O comportamento de uma criança delinquente difere do de uma criança com tendência antissocial, pois na delinquência já haveria defesas constituídas, com ganhos secundários, que dificultariam a criança poder entrar em contato com sua desilusão inicial.

A tendência antissocial, que seria normal até nos bons lares, está se transformando rapidamente em destrutividade, violência e delinquência para Maia (2002). Segundo Winnicott (1964), como seria uma criança dentro dos parâmetros normais? Alguém que cresce, interage satisfatoriamente, come ou brinca. Se uma criança normal tem confiança em suas figuras parentais, ela usará de todos os meios possíveis para se colocar, se impor, botando a prova seu poder de destruir, consumir, etc. Mas a ideia aqui é que, se ela tiver alguma dúvida em relação à estabilidade da relação entre o pai e a mãe, ou seja, se o quadro de referências de sua vida tiver sido desfeito, ela deixa de se sentir livre, se torna angustiada e muitas vezes se verá buscando em outros lugares, essa estabilidade que lhe faltou em seu próprio lar.

Um exemplo, que o autor nos coloca é de uma criança que rouba açúcar. Segundo Winnicott, ela está procurando a boa mãe de quem ela tem o direito de tirar toda a doçura. Quando a criança rouba fora de casa, ela ainda está procurando a mãe, e ao mesmo tempo a autoridade paterna, figura que poderia colocar um limite no seu comportamento impulsivo. Winnicott afirma que na delinquência inteiramente desenvolvida, o que está presente é a busca da atenção da presença de um pai rigoroso, severo, que proteja a mãe quando ela for encontrada. O roubo seria o exemplo típico dessa necessidade imperiosa de chamar a atenção da figura do pai.

Percebemos que os atos antissociais, como a enurese noturna e o furto, indicam que pode haver esperança. Esperança da possibilidade da existência de uma mãe suficientemente boa. Winnicott (2005) nos aponta que até na raiva podemos ver uma indicação que ainda existe esperança. A criança é uma unidade, e é capaz de sentir o choque entre o que é concebível e o que realmente é possível de ser encontrado no que chamamos de realidade compartilhada. Quando uma criança rouba, ela deseja não o objeto roubado, mas sim o que ele contém de referência ao desejo de receber da mãe, o que não lhe foi dado. 
Após termos demonstrado o escopo teórico que norteará nossa compreensão das vicissitudes vividas por crianças e adolescentes atendidas pelo projeto do circo, seguiremos utilizando no próximo capítulo a descrição da metodologia escolhida para a demonstração comparativa dos casos, os participantes envolvidos e os procedimentos que foram adotados dentro do setting terapêutico com cada um dos dois casos. 
5

\section{Método, Participantes e Descrição dos Atendimentos Clínicos.}

\section{1 \\ O método de estudo de casos múltiplos em psicanálise}

Neste capítulo, falaremos de alguns casos que foram acolhidos pelo projeto e que receberam atendimento clínico pelo serviço de psicologia e a equipe de profissionais técnicos da ONG. O método utilizado foi o de estudo de casos múltiplos em psicanálise.

De acordo com esse método, o estudo de casos clínicos é percebido como uma ferramenta metodológica, e que seja qual caso for o caso estudado, seus resultados sempre emergirão de uma pergunta advinda do encontro de um pesquisador com um conjunto de eventos ou características ainda insuficientemente descritos, de acordo com a subjetividade de cada caso (VERZTMAN, 2009, p.70).

Segundo o autor, o pesquisador necessitará de um norte teórico, ou seja, "só se pode fazer adequadamente um estudo de caso se o caso em questão for considerado útil para avaliar uma grade analítica que foi seu ponto de partida” em Verztman (2009). No caso trata-se da teoria do desenvolvimento maturacional e da tendência antissocial, propostas por Winnicott (1956).

De acordo Verztman (2009), para que se construa a pesquisa, é necessário que sigamos os elementos da metodologia aplicada. A primeira premissa é que, o estudo esteja pautado em um referencial teórico psicanalítico. Outro ponto a seguir é que, seu objeto de estudo deve ser inexoravelmente construído em torno do atendimento clínico oferecido aos sujeitos relacionados ao objetivo da pesquisa. Todos os casos são de crianças e adolescentes que participam do projeto do Circo Social, moradores da favela do Cantagalo, com suas vidas marcadas pela violência.

Por fim, o método preconiza que o estudo seja acompanhado por um supervisor clínico, para que as discussões sejam enriquecidas com trocas de informações teóricas relevantes. 
O professor Sérgio Gomes ${ }^{6}$, da Universidade Federal do Rio de Janeiro (UFRJ), com ampla experiência teórica e clínica winnicottianas, foi o supervisor ao longo do trabalho psicoterapêutico aqui apresentado ${ }^{7}$ e coordenador de um grupo de estudos clínicos por dois anos, com a participação da pesquisadora.

De acordo com esse método é também importante que a pesquisa aconteça no meio onde os indivíduos vivem; os chamados ambientes naturais, em contraposição aos ambientes experimentais, artificialmente arranjados

Devido à imbricação do objeto em seu contexto, devemos sempre estudá-lo no ambiente que lhe dá sentido e configuração. Um estudo de caso é, portanto um método naturalístico, e é uma forma de estudo que visa a descrição e a compreensão do singular. Caracterizamos por singular, não o inconcebível objeto em si, mas o objeto em seu contexto. (VERZTMAN,2009, p.71)

O trabalho da clínica psicológica, aqui apresentado, é parte dos procedimentos metodológicos adotados. O trabalho consistiu em atendimentos realizados duas vezes por semana, dependendo do caso. A cada quinze dias, a família da criança ou adolescente era atendida em conjunto, ou em separado, da criança ou adolescente. No trabalho especifico com a psicóloga, os horários de atendimento eram previamente marcados, sempre sendo respeitando o horário da criança ou do adolescente de escola, ou de permanecer no projeto do Circo Social, executando alguma das oficinas artísticas.

Em alguns casos, eram feitas intervenções do assistente social do Núcleo. A intervenção desse profissional visava, a partir do estudo do caso, determinar se a família necessitava de auxílio em relação à garantia de seus direitos, como por exemplo, inserção nos programas do governo; orientação à rede de parceiros, como por exemplo, advogados - dentre outros serviços necessários.

Verztman (2009) aponta que a comparação feita pelo método é sempre

\footnotetext{
${ }^{6}$ Psicanalista, Doutorado em Psicologia Clínica pela Pontifícia Universidade Católica do Rio de Janeiro; Mestrado em Saúde Coletiva pelo IMS/UERJ; Supervisor de Estágio na Divisão de Psicologia Aplicada Profa. Isabel Adrados do Instituto de Psicologia da Universidade Federal do Rio de Janeiro; Psicoterapeuta Voluntario, Supervisor da Clínica Social de Psicanálise e Membro Associado do Instituto de Estudos da Complexidade.

${ }^{7}$ Alguns dos casos, por sua complexidade, também foram apresentados em grupos de estudos formados por professores de Serviço Social das Universidades do Estado do Rio de Janeiro - UERJ e da Universidade Federal Fluminense - UFF.
} 
uma comparação de modelos. Isso não quer dizer que se irá comparar sujeitos ou seu sofrimento psíquico, mas sim comparar modelos, abstrações que servem para dar parâmetros à prática clinica psicanalítica. É importante ressaltar que, para o autor, a comparação de modelos de subjetividade já existe desde o nascimento da própria psicanálise. As categorias das patologias, as formulações sobre formas distintas de lidar com conflitos, as descrições de tipos diferentes de fantasiar, entre inúmeros outros exemplos, implicam sempre em comparações de modelos de subjetividade. Quando estes modelos são descritos ou analisados, as referências são encontradas em paradigmas explícitos ou implícitos que serão representados por modelos de casos em Verztman (2009) A prática da psicanálise estará sempre sendo influenciada pelos múltiplos casos comparados, ou seja, um caso só encontra seu sentido na comparação com outro caso.

Para o autor, a vantagem de um estudo de casos múltiplos é a relativização do caso único como modelo para uma teoria, ou seja, a multiplicação de contextos clínicos que esse método produz, irá facilitar a percepção de determinados sintomas, estruturas, experiências, entre outros, que podem se repetir em diferentes contextos.

A seguir, seguiremos com os procedimentos metodológicos, sempre de acordo com os textos de Júlio Verztman e colaboradores, aqui mencionados. Eles consistem na descrição do espaço, dos pacientes atendidos e breve resumo das entrevistas de triagem, assinatura do termo de consentimento livre e esclarecido, descrição do percurso do tratamento, presença de supervisores em reuniões quinzenais e por fim, as análises dos resultados obtidos.

O setting, onde os atendimentos eram realizados, era composto pela sala da Psicologia, composta de jogos, brinquedos, uma casinha de bonecas, com duas famílias, uma mesa com quatro cadeiras de madeira e outras duas cadeiras com encosto largo, acolchoadas e confortáveis. Era sempre dito para a criança ou adolescente que o que dissessem ali, seria sigiloso. A preocupação essencial era mantermos com eles uma relação de confiança. Foi a partir desse material discursivo, que realizamos a análise do comportamento antissocial e delinquente apresentado em dois casos clínicos, de crianças e adolescentes, que foram atendidos pelo projeto do Circo Social e atendidos pelo serviço de psicologia deste projeto.

Era, portanto, parte do contrato de tratamento, que o que fosse dito por 
eles, através dos jogos e brincadeiras ou de conversas, só seria utilizado com o conhecimento deles. Essas crianças precisavam se sentir seguras e confiantes para verbalizar o que sentiam, ou evidenciar, através de jogos e brincadeiras, a relação de suas vidas emocionais com o mundo.

Durante o decorrer de todo o trabalho, o brincar na vida das crianças e adolescentes atendidos tornou se um fator preponderante para podermos compreender a vida emocional destas. E, a partir daí, propiciarmos atendimentos adequados para esses meninos e meninas, que mostravam em seus comportamentos antissociais e delinquentes, um pedido de ajuda e de socorro. Winnicott é enfático em afirmar que a tendência antissocial e a delinquência são pedidos de S.O.S, e não necessariamente uma “doença de criança” em Winnicott (1992). A criança delinquente nos pede socorro, para ser controlada por pessoas fortes, carinhosas e que lhe passem principalmente confiabilidade.

Utilizamos nos atendimentos o trabalho com brinquedos, jogos e em alguns casos, desenhos e produções artísticas das crianças e adolescentes, valorizando o brincar e a criatividade envolvida nesses atendimentos. Esses atendimentos eram realizados em conjunto com as atividades lúdicas e de criação propostas nas oficinas do circo social.

De acordo com o método, é preciso analisar os casos a partir de uma ampla possibilidade de categorias. Nesta pesquisa, foi construída a categoria “incidência da violência em crianças e adolescentes” e a categoria "tendência antissocial e comportamentos delinquentes”.

Segundo Verztman et all (2005) os resultados obtidos são os frutos de todos os passos pertinentes ao método, tais como o acompanhamento clínico de todos os sujeitos, levando-se em consideração a temporalidade: cronologia, narrativa de si no tempo, sensação de continuidade do tempo, vivencias do passado e dimensão do futuro.

\section{2 \\ Participantes, Encaminhamentos e Descrição dos atendimentos clínicos: os meninos e meninas do Projeto do Circo Social.}


Conforme o método e em consonância com os termos de toda pesquisa com seres humanos, o trabalho foi submetido ao Comitê de Ética da PUC-Rio, através de um termo de compromisso que as famílias de livre e espontânea vontade assinaram, para que os casos fossem descritos em um trabalho científico. O Termo de Consentimento tem como objetivo, na publicação dos resultados desta pesquisa, garantir que as identidades das crianças, adolescentes e famílias sejam mantidas no mais rigoroso sigilo e tratados com lisura e ética.

A seguir, a descrição dos participantes envolvidos nos atendimentos clínicos, o encaminhamento realizado pelos atores que compõe a rede social da favela, tais como postos de saúde, escolas, associação de moradores, dentre outros, o histórico familiar das crianças e adolescentes atendidos, além da descrição breve do relato das consultas terapêuticas, que agiram como facilitadores na compreensão da pesquisadora sobre as vicissitudes vividas pelas crianças e adolescentes em foco.

\section{Caso 1: Paulo}

Idade: Seis anos de idade.

Sexo: Masculino

Escolaridade: Ensino fundamental ( $1^{\circ}$ ano).

Encaminhamento: Paulo foi encaminhado pela escola por ter um comportamento agressivo com as outras crianças. As agressões aos colegas variavam entre puxões de cabelo, palavras obscenas e, num rompante de fúria, Paulo chegou a perfurar a mão de uma das meninas da sala com um pedaço de vidro. Segundo ele, a menina estava imitando seu jeito e isso o deixou irritado. O menino foi encaminhado pela Escola onde estudava com o rótulo de “criança sem conserto”.

Por diversas vezes, Paulo foi posto de castigo em sala de aula. O castigo consistia em que Paulo não conversasse com ninguém e nem mesmo pudesse realizar as atividades propostas pela professora. Paulo deveria ficar sentado, de costas para a turma, com a cabeça baixa e sem emitir qualquer tipo de comunicação. Caso quisesse sair para ir ao banheiro, deveria levantar a mão e, em silêncio, esperar que a professora fosse até ele, para dispensá-lo.

Segundo a professora, as vezes que Paulo permaneceu nesse castigo que tinha, segundo ela, o objetivo de mantê-lo calmo e obediente, ele saía da sala 
correndo e gritando quando ela o colocava de castigo. Segundo ainda a professora, Paulo "tocava o terror" na sala e adentrava as outras salas de outras turmas gritando socorro, dizendo que estava sendo "raptado" (sic) pela professora. Perguntada se havia entrado em contato com a família de Paulo, a professora nos disse que a mãe dele era uma viciada, que nunca estava em casa, e que o pai de Paulo havia sido morto na favela.

A avó materna de Paulo era a única referência de família que a Escola encontrou. Mesmo assim, as vindas da avó de Paulo à escola aconteciam uma vez por ano, apenas para fazer a matrícula da criança. Por ser muito idosa e ter problemas de saúde, a avó de Paulo não conseguia ir às reuniões. Paulo quase nunca participava de atividades extraclasses oferecidas, pois a assinatura que ele trazia no papel de liberação, com a assinatura obrigatória do responsável para que pudesse realizar a atividade, segundo a professora, não era a mesma que constava em sua matrícula escolar. A professora e diretora da Escola, “deduziram”” que Paulo havia pedido que outra pessoa assinasse. Por isso, não o deixavam ir para as atividades extraclasses, juntamente com as outras crianças. Segundo a professora de Paulo, “a gente não pode deixar ele fazer isso, é assinar em baixo para o que é errado, é falar para ele que pode ser um criminoso na escola sem problemas, coisa que já esta acontecendo quando ele desobedece a todos e quer fazer tudo do jeito dele, assim vai crescer um marginal daqueles bem perigosos” (sic).

Paulo aos seis anos de idade, já era considerado pela professora e diretora como uma criança que não tinha jeito - um mau elemento, uma má influência para as outras crianças. Elas encaminharam Paulo para atendimento psicológico no projeto Circo Social, por ser próximo a sua casa, e por temerem que Paulo pudesse ferir mais gravemente outras crianças da Escola. Segundo elas, somente um psicólogo poderia dar jeito nele. Questionadas do porque não terem ido à casa de Paulo, já que a avó dele não conseguia ir à Escola, ambas foram unânimes em responder que se tivessem tido essa atitude com cada criança cujos responsáveis não comparecessem as reuniões de pais e mestres, elas não fariam outra coisa, a não ser ir à casa das famílias. Perguntamos, então, se a Escola tinha alguma parceria com o conselho tutelar da região, e a diretora disse que eles nem pensariam em chamar o conselho tutelar para qualquer criança do morro, pois mesmo com a pacificação, a maioria das crianças dali eram filhos de traficantes ou tinham 
parentes no tráfico. Concluíam que isso as deixaria em uma situação muito delicada perante a comunidade.

Histórico Familiar: Paulo nasceu no morro do Cantagalo, onde sua família residia há quase quarenta anos. Os avós de Paulo eram antigos moradores da favela, seu avô faleceu quando Paulo ainda não era nascido, e sua avó não se casou novamente depois da morte de seu marido. A avó de Paulo teve oito filhos, tendo perdido cinco deles. O pai de Paulo era o filho mais velho de Marilda e de seu esposo Carlos, chamava-se Paulo também, e a criança foi registrada com o nome do pai em homenagem a ele. Paulo o pai, nunca foi um homem carinhoso em casa, por vezes agredia a senhora Marilda, e segundo ela, foi um dos motivos que levou marido seu à morte, já que Paulo também era envolvido com o tráfico de drogas local na época. Segundo Marilda, Paulo se tornou cada vez mais agressivo, o que tornou a vida da família muito difícil. Paulo também agredia o pai. O pai de Paulo faleceu em decorrência de um acidente vascular cerebral, que o deixou inválido por um ano, falecendo logo depois. Paulo, além de fazer parte do grupo de traficantes locais da época, também era usuário de drogas ilícitas, trazia maconha e cocaína para dentro de casa e sua mãe e seu pai eram obrigados a conviver com essa situação. Marilda diz que a vida com Paulo em casa era sempre muito incerta, pois o medo da polícia ou mesmo um traficante rival da favela vizinha, Pavãopavãozinho entrar em casa, e matar a família era uma grande e constante ameaça.

Marilda, em uma das visitas que a assistente social do núcleo fez a casa da família, que hoje reside no Morro do Pavão-Pavãozinho, contou que quando Paulo seu filho, já falecido e pai de Paulo (criança) resolveu constituir família, colocou toda a responsabilidade nas costas dela, já que quase não ficava em casa e Marilda tinha que tomar conta da esposa de seu filho, que também era viciada em drogas ilícitas e bandida. A esposa de Paulo, Adriana, era uma mulher com um extenso histórico de violência. Ficou presa por diversas vezes, em sua maioria por roubo, sendo um deles a mão armada, seguido de morte e, às vezes, por porte de drogas ilícitas. Mais uma vez presa, nessa ocasião, estava grávida de Paulo. Ela foi flagrada roubando no supermercado perto da residência da família.

Apesar de todos os percalços, Adriana soube que estava grávida do pequeno Paulo quando estava na cadeia. Segundo Marilda, Adriana pouco se alimentava na prisão, e quando era dia de visita, elas não mantinham uma 
comunicação satisfatória. As visitas, às vezes, eram em total silêncio. Marilda diz que era muito difícil pra ela, ir às visitas no presídio. A família de Adriana não a visitava e nem entrava em contato com ela desde que era adolescente, sendo praticamente criada nas ruas do Rio de Janeiro. Marilda dizia que ela era a única pessoa que poderia representar a família de Adriana, já que a própria família de sua nora sumiu sem deixar vestígios. Ela não se sentia confortável sendo revistada na porta de entrada do presídio. A gravidez de Adriana foi toda no presídio. As outras presas contaram para Marilda, que, a criança já estava quase nascendo quando a levaram para o hospital. A assistência por parte das carcereiras dentro do presídio era muito precária.

A criança nasceu com complicações respiratórias, tendo que ficar na UTI Neonatal por um período de duas semanas. Nessa época, a mãe estava presa, tendo ficado quase seis meses sem poder ver a criança. Foi à avó de Paulo, Marilda que junto com Paulo seu filho, trouxe a criança para casa, com menos de um mês de nascido, e lhe deu os primeiros cuidados. Segundo Marilda, Paulo não queria que seu filho ficasse na cadeia com sua mãe, e por ser uma pessoa conhecida e ter amigos infiltrados na polícia, conseguiu que seu filho fosse retirado e trazido por ele para casa. Adriana não viu seu filho até o momento em que foi solta do presídio. Logo, não pode amamentá-lo, nem dar os cuidados básicos pra ele. Pediu que o nome da criança fosse o mesmo do pai, para homenageá-lo, já que era seu primeiro filho homem de seu marido. O pequeno Paulo também era o primeiro filho de Adriana.

Segundo a avó, o relacionamento de seu filho com o neto era de muita proximidade. Quando Paulo trouxe o filho para casa, os cuidados eram muitos, desde trocar as fraldas, a levar o menino para passear pela favela. Ate os três anos de idade, a criança recebeu do pai carinho, atenção e cuidados que segundo Marilda, deixava ate os moradores da favela admirados, já que Paulo era reconhecido por sua crueldade. A criança conviveu com seu pai ate os três anos de idade

O pai de Paulo era conhecido na favela como um indivíduo que não temia bandidos e nem polícia. Era o sujeito que tinha a incumbência de cobrar dos usuários de drogas o dinheiro que não era recebido. Ou seja, era o homem que marcava todos para morrer. Em conversa com pessoas que o conheceram, era 
unânime o depoimento sobre ele: um sujeito frio, calculista e sem nenhuma piedade. Onde ele se encontrava podia se prever uma “crônica de morte anunciada”. Paulo pai foi assassinado pelo tráfico local quatro anos antes.

Segundo moradores, Paulo foi cortado ao meio por uma rajada de projeteis de arma de fogo. Essa cena foi assistida por seu filho Paulo que aos três anos foi obrigado pelos traficantes locais a presenciar a morte brutal de seu pai. A fala dos traficantes, segundo vizinhos, era que Paulo, filho, prestasse atenção no que estava acontecendo pra que nunca repetisse o que seu pai havia feito, ou seja, traído o tráfico, tendo sido considerado X9 da favela, por estes traficantes. E o corpo jogado do alto da favela do Pavão-Pavãozinho, numa região denominada Vietnã ou Caranguejo. Local de desova de cadáveres e do chamado Forno Microondas, nome designado à morte por incineração de corpos, que era feita colocandose o corpo da vítima dentro de pneus e incendiando-a ainda viva.

Na segunda visita à casa da família realizada pela equipe técnica, psicólogo e assistente social, Marilda contou que vivia com muitas dificuldades, tanto financeiras quanto de saúde. Dizia que não conseguia dar conta do seu neto, que, com seis anos, lhe dava apenas motivos para se envergonhar, já que roubava na escola, agredia as crianças e a professora. Disse que não ia às reuniões da Escola, pois era muito longe, ela mora no alto do morro do Pavão-Pavãozinho, e a escola de seu neto fica no Morro do Cantagalo. São morros irmãos, um anexo do outro, mas como ambos são muito íngremes a subida é dificultosa, e a avó de Paulo alegava não dispor do dinheiro para pagar a Kombi que fazia o percurso do pé do morro ate o alto dele.

A mãe de Paulo, Adriana, pouco conversava com a equipe, e quando o fazia, dizia que não tinha tempo para ficar com Paulo, que segundo ela, já não era uma criança tão pequena, e já estava crescido para se virar sozinho. Quando na presença de algum membro da equipe, Adriana relutava em olhar diretamente para estes, principalmente para a pesquisadora. Adriana virava o rosto e fingia que não estava ouvindo, olhando sempre para outro lugar da casa. Essa atitude foi discutida em vários momentos pelos membros da equipe, pois dava a impressão que Adriana mostrava uma demonstração de desdém e descomprometimento com o que estava ocorrendo com seu filho.

Adriana engravidou de mais uma criança quando seu marido ainda 
estava vivo. Uma menina, que está atualmente com quatro anos de idade, e que, não lhe dava nenhum trabalho, pois era uma criança quieta e obediente. Conta apenas que Paulo era a criança problema da casa, e por sua semelhança física com seu pai, provavelmente seu destino também seria o do tráfico de drogas e da bandidagem. Adriana atualmente encontra-se grávida de seu atual companheiro. Companheiro que não convive com a família, por não poder subir o morro já que é ligado à outra facção de traficantes do Complexo do Alemão. Disse que o conheceu através de amigos, e que logo engravidou dele. A criança em seu ventre é outra menina.

A relação de Adriana com Paulo era quase sempre pautada por brigas e discussões. Marilda conta que Paulo não conseguia receber uma ordem e ficar calmo ou quieto, ele sempre tinha que responder e agredir. Tinha o hábito de bater na cara das pessoas da casa, e que ela não suportava mais as agressões dele. Segundo ela, Paulo saia de manhã para a Escola e só voltava à noite, para comer e dormir. Questionadas sobre a falta de cuidados em relação a Paulo, tanto Adriana quanto Marilda responderam que não conseguiam lidar com o comportamento dele, e que seria melhor que ele não voltasse mais para casa, já que não ajudava a família, só trazia problemas.

É importante ressaltar, que as visitas que a equipe técnica do projeto marcava com a família, foram quase sempre desmarcadas por telefone pela própria família. As dificuldades em marcar as visitas, em conversar com a mãe e a avó de Paulo, e de trazê-las para participar do atendimento sempre foram muito marcantes. A avó, por diversos momentos ausentou-se da favela, indo para casa de parentes no interior do Rio de Janeiro. Essas mudanças faziam com que Paulo faltasse à Escola, aos atendimentos psicológicos e ao projeto do Circo. Durante os três anos que Paulo esteve no projeto (e em terapia), só estivemos com a família em apenas três encontros, que aconteceram em sua própria residência.

\section{Início da terapia 2010-2011}

A criança chegou ao primeiro dia para atendimento questionando o motivo de estar indo para um "médico de gente maluca", referindo-se ao trabalho 
da psicologia. As sessões de Paulo sempre eram remarcadas, pois este quase não comparecia, e quando vinha, o estimulávamos dizendo que faríamos trabalhos no computador. Mesmo com toda a dificuldade apresentada, Paulo, quando em atendimento, mostrava-se afetuoso, abraçando a terapeuta constantemente. Os abraços eram seguidos de frases como "eu te amo", "você cuida de mim” (sic). A transferência positiva de Paulo para com a figura da terapeuta era facilitadora para que ele começasse a sentir-se acolhido e, aos poucos, apresentar mudanças em seu comportamento, até então, visto por todos como difícil e "sem conserto".

Em um de seus atendimentos, Paulo se referiu à escola como um lugar de maus-tratos, e que não queria mais estudar, apenas aprender as coisas que as pessoas ensinam na rua. Questionado sobre o que seriam essas coisas, Paulo dizia que era fácil limpar carros e que as pessoas lhe davam dinheiro quando ele dançava para elas na praia. O tratamento que Paulo recebia das pessoas que não faziam parte de sua família e que o cercavam, era considerado por ele como carinhoso; em contraste com o que acontecia em sua casa, a avó e a mãe não mantinham com ele um vínculo afetuoso. As agressões vindas por parte da mãe eram sempre comentadas por Paulo como: “maluca”; “deu à louca” (sic), e que ele não chegava perto dela, para não ser agredido. Em função dessa fala de Paulo, a equipe de assistentes sociais foi à casa da família para conversar, mas não encontrou a mãe. A avó apenas limitava-se a dizer que não se meteria em confusão entre mãe e filho.

Paulo sabia das intervenções da equipe técnica, já que quando contava algo dessa magnitude em seu atendimento psicológico, era avisado de que essa situação seria passada para as outras "tias” (sic) da equipe. Esta comunicação garantia que Paulo mantivesse uma ligação de confiança e proteção conosco.

À medida que as sessões ocorriam, Paulo trazia para a sala de atendimento um cuidado extremado com os brinquedos ali utilizados. Dizia que tinha que mantê-los intactos para que não se perdessem ou quebrassem, pois não gostaria de encontrá-los danificados. A tentativa de reparação de Paulo denotava a busca por uma mudança saudável em sua vida. Por um período de mais de seis meses, Paulo conseguiu assumir um comportamento de vitalidade, e suas vindas ao circo começaram a ser diárias. Saía da Escola e vinha diretamente para o circo e, constantemente, buscava a terapeuta para ficar próximo. Em uma dessas vezes, chegou a trazer flores para a terapeuta, dizendo que elas não poderiam nunca 
murchar, pois representavam o amor dele a ela e ao circo.

O trabalho que realizamos enquanto terapeuta e a inserção de Paulo no circo social eram para que ele pudesse encontrar em ambos os espaços um lugar de afeto, cuidados e principalmente de acolhimento. Paulo sempre demonstrou ser um menino criativo. Participava de todas as brincadeiras e muitas vezes buscava criálas sózinho. Certa vez, com pedaços de pano e pequenos farrapos de figurinos utilizados no circo, vestiu-se de gênio da lâmpada, indo para todos os cantos realizar os desejos das pessoas que ali se encontravam. Perguntado qual seria seu grande desejo, ele nos contou que era ser feliz, como um passarinho que pode voar e ver tudo do alto, sem precisar ficar apenas em um lugar.

Os atendimentos eram pautados em brincadeiras e desenhos, bem como brincadeiras com massinhas de modelar. Paulo também ficava por um bom tempo brincando na casinha de bonecas, onde brincava de família. O comportamento da criança era de cuidar dos bonecos da casa, para que eles não se perdessem ou fossem machucados por alguém. A fala de Paulo era de que, os machucados que as crianças recebiam, ficariam para sempre na cabeça delas.

Nessa época, Paulo estava fazendo sete anos e teve como presente dos professores do circo uma festa de aniversário com bolas, brincadeiras, bolo e doces. Paulo dançava todas as músicas e fez questão de guardar um pedaço do bolo para a psicóloga, dizendo que era para que ela se alimentasse quando tivesse fome.

Suas vindas aos atendimentos até sua saída da favela foram marcadas pela estimulação criativa, tendo como pano de fundo o acolhimento por parte de todo o grupo do circo, recebido por Paulo de uma forma amorosa, já que este o estimulava a vir constantemente para o espaço. Na Escola, segundo a professora, Paulo estava mais participativo, ainda muito “teimoso” (sic), mas não estava mais agredindo fisicamente seus colegas e agora só fazia dançar pela sala. A professora conta que o passatempo predileto dele era dançar e fazer coreografias com as outras crianças quando estava no recreio. As notas ainda continuavam baixas, mas Paulo estava mais aberto ao contato e menos agressivo.

Dona Marilda, por viver sozinha boa parte do tempo, já que Adriana estava grávida de outra criança e ficava mais tempo em outra favela com o atual companheiro, começou a viajar periodicamente. Justamente quando Paulo apresentava melhora, fez a primeira viagem, de inúmeras outras, que ocorreram 
durante todo o processo em que Paulo esteve em tratamento conosco, levando-o com ela. Paulo ficou sem atendimento por um período de quase cinco meses.

\section{Ano de 2011 a 2012}

Quando Paulo retornou à favela, começou a se juntar com outros meninos e meninas para saquear os bares, entrando nas casas de moradores pela janela. Paulo voltava à favela onde nasceu com um comportamento não mais antissocial, mas sim, delinquente. Era comum ver Paulo na praia de Copacabana praticando pequenos roubos de bolsas e relógios de turistas. Segundo ele, era mais fácil pegar de turistas: “tia, isso é mamão com açúcar” (sic).

Quando retornou aos atendimentos com a psicologia, vinha poucas vezes, e decidiu por si só recomeçar as atividades do circo. Frequentou assiduamente às aulas do circo. Deixou de ir à Escola todos os dias; só ia quando queria; e quando ia, era sempre expulso de sala de aula. Teve suspensão de uma semana da Escola. Mesmo com a intervenção da equipe social, a diretora mantevese irredutível.

Esse espaço de tempo em que Paulo ficou longe de todo o atendimento, marcou um retrocesso em seu comportamento, principalmente na Escola. Adriana retornara para casa, mas não poderia mais sair dela, ficando prisioneira em seu próprio espaço. Essa situação era passada para a criança como uma punição dos traficantes locais e Paulo repetia que sua mãe estava "perdida na vida” se colocasse os pés para fora de casa. Disse à psicóloga que se a mãe saísse levaria "um teco no meio da testa” (sic). A fala de Paulo era de risos e achando que sua mãe merecia viver toda essa situação. Dizia “tia, ela buscou isso pra ela” (sic), quando perguntado sobre o que achava da situação da mãe.

Mesmo não continuando com a frequência de antes nos atendimentos psicológicos, Paulo decidiu permanecer nas aulas de circo, quando achava que sua presença era sentida na aula. Segundo ele, as aulas não eram mais as mesmas sem sua presença. Então, a terapeuta o acompanhava às aulas de circo, se mostrando presente a todo o momento. Paulo demonstrava sua alegria e gratidão indo sempre dar um beijo ou acenando para ela. Gritava o nome da terapeuta, no momento que a avistava. 
Quando Paulo estava nas aulas do circo e nas atividades ali propostas, como aula de tecido, malabares, dentre outras, ele se saía muito bem, fazia tudo que lhe determinavam, sendo considerado por muitos ali um verdadeiro futuro artista. Sempre muito desenvolto, atraía a atenção para si com facilidade, realizava as coreografias e se incumbia de ensinar aos outros os passos aprendidos.

O retorno de Paulo teve a duração de um ano e dois meses. Depois disso, sua avó teve que sair do morro novamente, pois Adriana tinha sido presa e, só poderia voltar ao morro se o dono da boca consentisse. A avó, com medo de algum tipo de represália, novamente viajou com Paulo e sua irmã para a casa de parentes.

\section{Término - 2012 a 2013}

Na sua volta, Paulo não retornou ao atendimento psicológico e tampouco para as atividades do circo. Paulo estava agora com nove anos de idade e passou a se intitular de "Paula”. Passou a exibir um comportamento extremamente feminino, usando roupas de mulher, maquiagem e cabelo com presilhas ou enfeites que ganhava de amigas. Paulo dizia fazer o que quisesse com o corpo, "se eu quero dar a bunda eu dou, eu gosto, ninguém tem nada a ver com isso” (sic). Esse período de afastamento foi marcado por uma ruptura não apenas da aliança entre a terapeuta e o paciente, mas entre Paulo e a possibilidade de dar continuidade à sua vida criativa dentro do circo. Agora ele andava com meninas da favela e dizia ter um namorado mais velho. Todas as tentativas de trazê-lo para atendimento sempre foram frustradas, pois Paulo dizia que não precisava de tia alguma para conversar, já que agora tinha seu próprio "homem”, que fazia isso para ele. Esse homem era um dos amigos que comumente Paulo andava na favela. Tinha também uma grande amiga, Fábia, de quem, aparentemente, aceitava as sugestões.

Fábia era uma das meninas que andavam com Paulo na favela, e o acompanhava em suas idas à praia, para fazer os pequenos roubos. Fábia era mais velha, porém muito franzina. Tinha uma expressão masculinizada, andava sempre com um boné e de shorts, nunca de vestidos. Fábia era uma menina amorosa com Paulo, e a quem ele ouvia, quando estava tentando roubar alguém na favela. Fábia não recebia atendimento, pois não morava na favela.

Fábia morava na favela vizinha e tomava conta de um irmão pequeno 
de sete meses, enquanto sua mãe trabalhava. Tinha em torno de 14 anos e fazia papel de mãe de Paulo e de seu próprio irmão. Fábia e Paulo cuidavam um do outro. Segundo Paulo, Fábia era sua irmã mais velha, que amava muito e de quem ele nunca iria se separar.

Em uma conversa com Fábia e a equipe social do projeto, em uma tentativa de ajudá-la, contou que não gostava quando Paulo roubava as madames de Copacabana, e que ela tinha medo de ser presa e apanhar dos policiais. Mesmo com as orientações da equipe para que nos desse seu endereço e pudéssemos visitar sua casa, Fábia insistia em dizer que se fôssemos a sua casa, não encontraríamos ninguém, pois sua mãe estava sempre trabalhando fora. Além disso, a equipe do projeto era impedida de entrar na outra favela, pois a facção do comando era diferente da favela de origem do projeto. Portanto, não havia por parte da ONG, que patrocinava o projeto social do circo, um movimento de dar condições para que os profissionais pudessem atuar nesse caso específico.

No último contato com Paulo, este chegou à sala da equipe social do projeto, procurando a psicóloga e a assistente social que acompanhavam a família, e perguntou se elas ainda gostavam dele. De pronto disseram que sim, que gostavam dele e que gostariam que ele retornasse ao circo e aos atendimentos. Mas Paulo, com maquiagem e roupas bem justas, chegou perto de ambas e cuspiu nelas. Ao fazer isso disse que "agora vocês não vão mandar em mim, e eu vou ser quem eu quiser. Tia, eu odeio o circo" (sic). Sem se desculpar, saiu correndo do local onde o projeto se encontrava.

Na tentativa de compreender o comportamento que Paulo apresentava e buscar auxílio em sua família, a terapeuta foi a casa onde residiam Paulo, sua avó, sua irmã e a mãe. E em uma conversa, novamente na tentativa de que participassem mais da vida de Paulo e que elucidassem o que havia ocorrido com ele em sua ultima viagem com a família. Ambas, mãe e avó, disseram que estavam de mãos atadas no caso da criança, e que Paulo não contava nada do que acontecia com ele, pois ali ninguém se metia na vida de ninguém. Quando perguntamos sobre as idas da família para fora da favela e o comportamento de Paulo com mudanças tão drásticas, a avó contou que ele ficava brincando muito com os primos e os coleguinhas da mesma rua e que, aparentemente, nada significativo acontecera com ele, para que seu comportamento mudasse. Segundo ela, Paulo estava cada dia mais 
parecida com seu filho, morto por traficantes, e que isso a deixava muito triste, mas que não poderia fazer nada, pois era uma escolha de Paulo.

Adriana, grávida de outra criança, foi taxativa ao dizer que não iria deixar sua vida de paz com seu novo marido para tentar ajudar Paulo, que não tinha mais jeito. Dona Marilda disse também não conseguir mais “parar” a criança e que ele estava por conta própria. Se ele decidiu ser uma mulher, que fizesse sua vida como uma mulher nas ruas de Copacabana. Disse também que ficava esperando “ $o$ pessoal da UPP pegar ele e levar para a FEBEM” (sic). Segundo a avó, os policiais da UPP não ajudavam em nada quando ela fazia alguma reclamação do comportamento de Paulo, mas na hora de humilhar e levar uma pessoa da favela pra delegacia eles sabiam fazer muito bem. Falou também que não acreditava que o tráfico havia parado suas atividades, já que os meninos do movimento ainda continuam vendendo drogas. E temia de certa forma que Paulo fosse pego pelos traficantes. "Eu prefiro que os UPPs peguem ele e leve do que os bandidinhos que estão aqui." (sic).

Depois dessas intervenções com a família, Paulo não mais frequentou o atendimento terapêutico, o circo e à Escola. A criança era vista esporadicamente andando pela favela com outras meninas e meninos, e quando não, estava nas ruas do entorno da favela praticando furtos e roubos. Paulo não mais frequentava o morro com seu nome, já que se intitulou Paula, e era assim que as pessoas da favela o reconheciam agora.

Os limites impostos pela ONG em relação aos atendimentos com o serviço social e a garantia de direitos dessa criança, foram importantes empecilhos para que não houvesse uma real melhora no seu quadro. Esses limites se referiam ao impedimento que qualquer técnico social encaminhasse crianças e adolescentes da favela para órgãos de proteção a criança e ao adolescente. O pretexto da ONG era que por ter um “bom acordo e relação pacífica com a facção local” (sic), isso poderia servir de pretexto para que o trabalho ali na favela fosse impedido pelos traficantes. Tal postura da ONG sempre foi questionada pela equipe técnica social do projeto, mas como de costume, não éramos ouvidos e sim estimulados apenas a cumprirmos nosso papel de trabalhar dentro do projeto e não sermos "superheróis” (sic). O caso de Paulo hoje continua em aberto. 


\section{Caso 2: Jonas}

Idade: 11 anos de idade.

Sexo: Masculino

Escolaridade: Ensino fundamental $\left(1^{\circ}\right.$ ano).

Encaminhamento: Jonas foi encaminhado para atendimento no serviço de psicologia do projeto do circo social, por meio de uma demanda espontânea vinda de sua ida ao posto de saúde do Cantagalo. Jonas chegou ao posto médico levado pela vizinha, pois apresentava febre alta. O médico sugeriu a vizinha da família, Olinda, que ele deveria ser encaminhado para tratamento psiquiátrico, pois a criança; segundo o parecer médico naquele momento: apresentava machucados pelo corpo provenientes de surras, além de um comportamento agressivo.

Histórico Familiar: Jonas era o filho mais velho, tinha uma irmã de nove anos de idade, e vivia com seu pai e mãe em uma casa invadida por eles, no morro do Cantagalo. A mãe de Jonas, a senhora Carla, jovem, com cerca de 35 anos, e seu pai o senhor Adailton 40. Quando Jonas nasceu, Carla não conseguia cuidar da criança de forma adequada, segundo ela, Jonas chorava muito, a noite toda com cólicas, e quando ela tentava dar o peito o menino não conseguia “pegar”. Muitas vezes, Carla estava se sentindo mal por conta de sua doença, e não conseguia chegar ao bercinho de Jonas para dar-lhe o peito, e a criança chorava muito por conta disso. Falou que ninguém a ajudou em cuidar de seu primeiro filho, e que com a doença, tudo ficava mais complicado.

Segundo Carla, muitas vezes, quando Jonas ainda era recém nascido, o pai da criança o levava de casa para a rua. Carla não sabe o que acontecia, apenas que ele chegava com a criança chorando, e dizia que ela chorava assim porque estava sendo muito mimado pela mãe. Carla tinha medo de perguntar onde seu filho estava, e dizia que na época apesar das agressões de seu marido, confiava nele como pai, e sabia que Jonas estava em segurança. Mesmo que o pai tenha tentado matar seu filho, afogando-o num tanque, em um dia que chegou em casa alcoolizado e a criança estava chorando muito.

Jonas de 11 anos era uma criança de estatura grande, que facilmente era confundido com um adolescente. Sua altura chega em torno de 1,70. Os pais de Jonas aparentavam idade muito maior do que possuíam, e Jonas se assemelhava a seus pais nesse tocante. A mãe de Jonas tinha diabetes e teve uma de suas pernas 
amputadas havia cinco anos, e por isso não podia mais trabalhar. O pai trabalhava fazendo bicos como pedreiro, mas devido a uma tuberculose e o vicio do álcool, os trabalhos estavam muito escassos. Eram constantes as brigas entre o casal, e entre Jonas e seu pai. O pai quando chegava em casa, espancava a família toda, sempre dizendo que eles pegavam seu dinheiro, ou mesmo que sumiam com algum objeto pessoal seu. As surras que Jonas tomava de seu pai já eram tão habituais, que o menino já não chorava quando apanhava. A mãe de Jonas, que também era espancada pelo marido, temia procurar a polícia ou mesmo a UPP para denunciá-lo, pois receava que o marido ficasse com raiva e fosse embora de casa, deixando-a sozinha com as duas crianças.

A família era muito conhecida no morro, por causa das constantes brigas e das crianças machucadas pelos becos do morro. Essa situação veio se agravando desde que Jonas tinha meses. Segundo a mãe, o pai de Jonas o tirou de seus braços e tentou afogar a criança no tanque de uma vizinha, tendo sido impedido pelos moradores da favela. Mesmo assim, a mãe de Jonas não denunciava seu marido, ou mesmo saía da casa onde viviam. A mãe era de origem nordestina, e não possuía família no Rio de Janeiro. Quando conheceu o pai de Jonas, logo engravidou, eles invadiram uma casa abandonada na favela, e ali permaneceram.

Segundo a Carla, Jonas sempre foi uma criança muito calada, arredia a qualquer tipo de contato, sempre brincando sozinho, e costumava quebrar os poucos brinquedos que tinha na casa. Não gostava que o chamassem de "Doquinha” apelido derivado do apelido de seu pai na favela, "Doca”. Fazia questão de afirmar que não era como o pai e não se parecia com ele. Fisicamente Jonas se parecia mais com sua mãe, principalmente na altura. Com 14 anos, Jonas já estava com mais de 1,80.

A vizinha Olinda conviveu com a família desde que esta se mudou para a casa abandonada no morro. Segundo ela, as surras que todos levam do pai de Jonas eram ouvidas por todos os moradores dos arredores do beco. As crianças choravam, gritavam, e ele continuava batendo nelas. Essa foi a fala de Olinda, que levou Jonas ao médico no dia em que ele estava com uma febre muito alta, e não tinha medicação em casa para tomar.

Porem, Jonas, com onze anos de idade, já participava do “movimento do tráfico de drogas no morro”. Por sua estatura grande, Jonas serviu como um 
soldado para o tráfico, logo de pronto. A vizinha Olinda, dizia que Jonas estava andando com os traficantes, e quando a família e ela se deram conta, a criança já estava armada dentro do morro. Havia se tornado um soldado do tráfico. Nesse período em que Jonas começou a fazer parte do tráfico, o dinheiro em casa não faltava, e a família recebia gás, comida, e medicações para a senhora Carla. As surras já não eram mais ouvidas pelos moradores. Jonas; em uma noite que seu pai resolveu aparecer em casa; depois de dias sem dar noticias; expulsou-o de casa, e bateu nele junto com mais dois companheiros do tráfico. A fala de Jonas era de que o pai nunca mais tocaria a mão em sua mãe, e em sua irmã, e que, a partir daquele momento, ele se tornaria o chefe da casa.

Carla contou que nessa época, Jonas andava com roupas caras, mas não podia sair do morro, e ela tinha que guardar as armas dos traficantes em sua casa. Sua filha de sete anos assistia à toda essa situação, e começou a apresentar enurese noturna, e dormia o dia todo. Jonas também sempre teve enurese noturna, e isso o deixava envergonhado. A mãe conta que quando ocorria guerra entre policiais e os traficantes, a primeira coisa que pensava era de que seu filho seria morto por um policial. Como tinha dificuldades de mobilidade, Carla se mantinha sempre dentro de casa, indo apenas para a porta onde ficava sentada em uma cadeira no beco onde moravam.

O pai de Jonas continuava morando no morro, vez ou outra entrava em casa, pegava algum dinheiro e sumia por dias sem dar notícias. A relação de Jonas com o pai era pautada por agressões verbais com ameaças. Elas partiam de Jonas, e, segundo a mãe, intensificaram-se desde que o menino entrou para o trafico. Segundo Carla, um dos traficantes teria dito que se Jonas quisesse, eles dariam um sumiço em seu pai, mas Jonas não quis, e disse que ele mesmo daria um jeito nele. A mãe fala que Jonas, por ser alto e forte, sempre foi confundido com um garoto mais velho, e que o pai quase não batia nele depois dele ter crescido muito. Apanhava pouco segundo ela, mas a filha pequena e a própria Carla apanhavam muito de Doca.

Apesar de saber que seus filhos estavam sofrendo, e que a entrada de Jonas no tráfico em nada melhoraria a vida da família, Carla manteve-se inerte com relação a toda essa situação. Disse que os abusos que sofreu do pai de Jonas não se comparavam à dor que ela sentia quando via seu filho no tráfico, ou 
guardando armas dentro de casa. Mas que era uma escolha dele, e que se ele estava feliz, para ela estava tudo bem.

A relação da mãe com Jonas era muito superficial, pouco se falavam, e Jonas não mantinha com a mãe uma afetividade como era demonstrada com seus amigos do tráfico, aos quais ele chamava de "irmãos da guerra” (sic). Essa palavra foi repetida várias vezes por Jonas nos momentos de atendimento. No tráfico ele se sentia acolhido, aceito e tinha sua autoestima elevada. O respeito que impunha aos moradores o deixava numa posição de adulto, e não mais uma criança que apanhava de seu pai. Agora ele poderia comprar o que a mãe quisesse e dar uma boa escola para sua irmã. Essas eram as palavras da criança.

Mas o tráfico ao mesmo tempo em que deixava Jonas numa posição mais privilegiada em casa, o aprisionava na favela. Ele não voltou a estudar, não tinha amigos fora do tráfico, e não lhe era permitido sair da favela, pois poderia ser morto por algum traficante rival, ou mesmo pela polícia. Segundo a vizinha Olinda, Jonas um dia entrou em sua casa com muita febre, e contou que viu um companheiro do tráfico ser morto em sua frente pelos próprios traficantes locais. Nesse momento, Jonas disse para a vizinha que não queria mais voltar ao tráfico porque tinha medo de morrer. Foi então que ela, conversando com a mãe de Jonas, decidiu levá-lo ao posto de saúde para que alguém pudesse ajudá-lo. A mãe, sem condições de levá-lo, solicitou que a vizinha o fizesse. A vizinha também era madrinha da irmã de Jonas, e chegou a dizer que se sentia responsável pelo menino ter entrado na vida do crime. Achava que poderia ter impedido de alguma forma o contato de Jonas com os traficantes.

O papel de Olinda na vida da família sempre foi muito importante. Olinda diz que quando eles vieram morar na favela, Carla sempre muito doente, não podia cuidar direito dos meninos, e ela o fazia. Chegou a ser chamada pra ser madrinha da filha mais nova de Carla, e aceitou de forma satisfatória. Segundo ela, a menina era calma, dócil e meiga. Não apresentava comportamento similar ao do irmão, mesmo sofrendo surras contínuas do pai.

Na escola, a menina apresentava sempre boas notas, e executava as lições e trabalhos de casa sem problemas. Olinda disse que Jonas não gostava que o ajudassem, mostrando-se sempre muito retraído, conversava pouco, usava muita gíria, e quase não gostava que o abraçassem. Olinda conta que os momentos de 
carinho entre pais e filhos, eram raros, e apenas uma vez viu Doca, pai de Jonas, abraçá-lo na rua, mas que, rapidamente o menino saiu dos braços do pai.

A família com poucos recursos financeiros, muitas vezes não tinha como comprar comida, já que o dinheiro que Doca trazia para casa era gasto em bebidas. Olinda conta que quando a situação da família estava muito "apertada” (sic), ela fazia comida em sua própria casa e levava para a família de Carla. As crianças sempre muito magras e estavam sempre com fome. Olinda lembra que os meninos praticamente devoravam qualquer alimento que ela trouxesse. Segundo Olinda “dava pena de ver as crianças naquele estado” (sic).

Olinda nos contou que por muitas vezes quis ligar para a polícia nos momentos em que Doca estava surrando a família, mas que perdia a coragem por medo de que ele soubesse de alguma maneira o que acontecia. Também disse que chegou a pensar em falar com os traficantes da favela, mas também não quis se meter com eles, já que temia que também tivesse alguma represália da parte do próprio Doca. Contou que Carla algumas vezes chegou a arrumar as suas coisas para ir embora da favela com as crianças, mas desistia, quando pensava que iria morar na rua. Sua família de origem não morava no Rio de Janeiro, e ela não falava com eles desde que foi morar com Doca na favela.

Carla contou que era de origem muito pobre, morava na roça no Nordeste do país, mas mesmo com poucos recursos financeiros, tinha de seus pais, muito carinho e atenção. Quando fez 17 anos resolveu vir para o Rio de Janeiro, em busca de uma melhor qualidade de vida. Conseguiu então, com amigas que moravam em Ipanema na zona sul do Rio de Janeiro, um emprego na casa de uma família. Conta sorrindo as vezes que brincava com os irmãos e irmãs em meio as plantações de cana de açúcar, ou no rio próximo a sua casa. Segundo Carla, sua vida era muito diferente do que a vive hoje na favela. Contou que foi morar com Doca, que conheceu assim que chegou ao Rio de Janeiro, pois já tinha engravidado de Jonas. Com medo de ser expulsa da casa da família que trabalhava, praticamente fugiu de lá e foi morar com seu então marido na favela, em uma casa sem água, luz, e piso apenas de tábuas.

Conta que a casa era praticamente de tábuas soltas, e que com o tempo, Doca e as famílias próximas, principalmente a família de Olinda, ajudavam com algum material de construção. Conta que quando ainda estava grávida, Doca era 
mais carinhoso e atencioso, já ficava alcoolizado, mas que não batia nela. Ele trabalhava como ajudante de pedreiro, e foi com a ajuda das pessoas que Doca construiu a casa que hoje moram. A casa tem ligações clandestinas, tanto de água quanto de luz, e fica localizada em um dos becos mais distantes da favela, um local de difícil acesso.

Carla teve uma de suas pernas amputadas, depois que sofreu uma queda e segundo ela, a perna "gangrenou” (sic). Isso ocorreu logo que Jonas nasceu. Jonas ainda era um bebê de meses, quando Carla teve que ficar internada por conta da amputação. Quem tomou conta do pequeno Jonas foi a vizinha Olinda, que segundo Carla, o tratou com carinho e cuidou dele até Carla poder voltar pra casa. Doca, na época de nascimento de Jonas, não ficava mais constantemente em casa, e as vezes que retornava, chegava alcoolizado, e o dinheiro que trazia já não dava para a família comprar alimentação. Carla se viu na situação de precisar da ajuda das pessoas da comunidade. Disse que nunca procurou ajuda do governo, pois as pessoas diziam que só quem recebia ajuda era quem tinha "algum conhecido no governo” (sic), e por esse motivo nunca achou-se no direito de pelo menos procurar por ela mesma alguma medida de proteção para sua família. Não apenas em relação à ajuda financeira, bem como para proteção contra os abusos de seu marido.

Carla tinha duas muletas que foram doadas por uma das famílias moradoras da favela, e se locomovia com elas pela casa. A dificuldade em subir e descer a favela era muito grande, e, por esse motivo, Carla quase não saía do beco. Olinda lhe ajudava quando precisava comprar alguma comida, ou mesmo buscar remédios para sua diabetes no Posto de Saúde. Pelo menos uma vez por mês, Carla sempre ia ao posto de saúde assinar um termo, que dava à Olinda poderes legais para retirar os medicamentos que necessita.

Jonas foi trazido por Olinda, para seu primeiro atendimento no serviço de psicologia do projeto do circo social.

\section{Início do atendimento 2010-2011}

Como mencionado anteriormente, a criança veio para seu primeiro atendimento com a psicóloga acompanhado pela vizinha da família, Olinda e não por sua mãe, Carla. 
Quando Olinda trouxe Jonas para atendimento, me mostrou uma carta escrita por Carla, na qual pedia socorro: seu filho estava no "movimento da favela" e ela temia que essa situação ficasse pior, pois constantemente Jonas carregava armas de fogo para dentro de casa, e ela não conseguia se sentir em paz.

Jonas era muito arredio, pouco falava e, enquanto Olinda relatava o motivo que havia trazido Jonas para o atendimento, ele demonstrava uma expressão de irritação e desconforto por estar na presença de uma psicóloga e uma sala de atendimento com uma decoração muito infantil.

Sugerimos que Olinda saísse um pouco da sala para que Jonas pudesse ficar a sós com a terapeuta. Sinalizamos também que seriam realizadas visitas à casa de Jonas, visitas essas, efetuadas pela equipe técnica social do projeto. Ficou acordado também que os atendimentos do menino teriam que ser acompanhados pela família. Olinda logo se apressou em dizer que Carla era deficiente, e que subir o morro para ela seria muito complicado. Mesmo assim, deixamos claro que o acompanhamento familiar era de suma importância para o andamento do atendimento da criança, e que a família seria fundamental para que Jonas obtivesse uma melhor condição de vida. Nesse dia, Jonas não falou com a terapeuta. Perguntamos se gostaria de vir para os atendimentos, esclarecendo que ali seria um lugar apenas para que ele pudesse ser mais feliz. Ele consentiu balançando a cabeça positivamente.

Jonas apareceu para seu primeiro atendimento, como seria normal daqui por diante, sózinho, sem a presença de um responsável. Chegou no horário marcado e ficou quieto esperando que a psicóloga lhe chamasse para dentro da sala. Nesse encontro, perguntamos à Jonas se ele gostaria de ter encontros semanais com a terapeuta, nos quais ele poderia dizer tudo que gostaria. Que aquele seria seu horário e dia. Jonas apenas assentiu com a cabeça e continuou sem emitir uma palavra. Em seu segundo atendimento, chegou a dizer que a sala era muito cheia de “coisas” e que não parecia uma sala para conversar. Ele procurava sempre estar sentado, ou às vezes até deitado nas poltronas da sala.

Como era de hábito nas sessões com as crianças, mostramos a sala de atendimento, seus recursos, tais como: folhas para desenhar, lápis de cor, canetas coloridas, os brinquedos como massinhas, a casinha de bonecas, os livros infantis, a caixa com vários brinquedos, como carrinhos; animais selvagens; animais de 
fazenda; bolas; bola de gude; corda para pular; raquete de tênis; joguinho de botão; trenzinhos; bonecos e bonecas de vários tamanhos; jogos de tabuleiro; dominó; jogos de cartas; jogo de damas; pega varetas; um jogo do pequeno construtor; um jogo de montar com peças soltas; quebra cabeças e alguns brinquedos quebrados. Jonas mantinha-se calado e apenas observava com certa distância todos os brinquedos. Não mexeu em nada, apenas ficou sentado na cadeira.

O silêncio de Jonas nas sessões era comum. Quando falava, apenas perguntava se poderia mexer em algo, e preferia sempre pegar algum livro e ficar lendo sozinho. Jonas, em seus primeiros atendimentos, mostrava-se sempre muito desconfiado. Chegou a perguntar o motivo de estar sendo obrigado a participar de sessões com uma psicóloga. Explicamos que não havia obrigação para que ele estivesse ali, mostrando a ele que aquele era apenas um espaço possível de acolhimento, no qual ele poderia expor o que sentia, as coisas que, muitas vezes, não contava para ninguém. Dissemos também que tudo que falasse seria tratado com sigilo, que a terapeuta não comentaria nada com sua mãe. Explicamos que, sua família só seria acionada, caso tivéssemos certeza de que algo que falasse ou fizesse, pudesse acarretar danos físicos e emocionais para ele. Jonas aceitou o contrato de atendimento e, apesar de pouca idade, disse que não gostaria de ficar brincando e sim conversando.

Apesar disso, falava muito pouco nos atendimentos iniciais, mas não faltava às sessões, vindo sozinho muitas vezes, de sua casa direto para o atendimento.

Na terceira sessão, a equipe social foi à casa de Jonas, onde terapeuta e assistente social puderam conversar com a mãe da criança, e dizer-lhe da importância de sua presença nos dias de atendimento com a família. Foi quando Carla expôs com maior vigor a história de que seu filho estava no tráfico de drogas, que andava armado e que essa vida estava tirando seu sossego. Colocou que Jonas, por ser um menino alto e forte, estava sendo usado como solado do tráfico, e que ela tinha medo de que ele fosse morto.

Contou do relacionamento conturbado com o do pai de Jonas, e das dificuldades que a família passava em relação aos problemas financeiros. A assistente social orientou-a a procurar o CRAS da comunidade, mas Carla insistia em dizer que não teria direito a benefício algum, colocando que isso só era 
benefício para pessoas que possuíam algum conhecido no governo. Apesar das orientações da assistente social, Carla manteve-se com essa postura até o fim da visita. Apesar disso, ficou acordado que Carla iria ao atendimento familiar uma vez a cada quinze dias, e que sem isso, o atendimento da criança seria prejudicado. Então Carla começou, apesar de toda a dificuldade, a vir de quinze em quinze dias para o atendimento, ora com o serviço social, ora com o serviço de psicologia do projeto.

Jonas havia sido avisado do dia e horário que a equipe social do projeto iria à sua casa e quase no final desta visita, ele apareceu na porta, sem camisa e com uma bermuda que deixava transparecer que havia uma arma em seu poder. Quando Jonas viu a equipe, sorriu e disse para a mãe, "essa é minha psicóloga de lá do circo” (sic). Entrou na casa e, ainda sorrindo, acompanhou a equipe até a saída.

Depois dessa primeira visita à família, em umas das sessões, Jonas falou sobre sua vida, e a entrada no tráfico de drogas. Nesse momento, Jonas que pouco falava, começou a se expressar com gírias e movimentos com os braços para explicar o tamanho, por exemplo, da arma que foi presenteada por um traficante que ele considerava como um "irmão de guerra" (sic), e que o fazia sentir-se um "homem importante e com responsabilidade" (sic).

Os rompantes de agressividade de Jonas se tornaram comuns durante os atendimentos que se seguiram, quando conversávamos sobre o tráfico de drogas na favela, sua posição dentro dele e de como ele ainda criança, andava armado pela favela. Mesmo que expuséssemos o perigo no qual vivia, estando vinculado ao tráfico de drogas, Jonas parecia buscar sempre formas de dizer que se sentia protegido e acolhido dentro da boca de fumo. Chegou ao ponto de trazer para o atendimento uma arma. Quando Jonas trouxe a arma e mostrou-a a psicóloga, nesse momento, pedimos que deixasse a arma na mesa e que não a levasse mais para lugar algum. Apesar da insistência da psicóloga, Jonas dizia que era a arma que ele costumava usar, que já estava habituado e sabia muito bem manuseá-la. Mesmo com sua fala, solicitamos que um dos mediadores de conflito que trabalhavam no projeto, pegasse a arma e a levasse de volta de onde veio. Nesse dia, Jonas ficou muito agressivo e saiu da sessão, pois a arma foi tirada dele e levada pelo mediador para seus donos. Indagamo-nos sobre a possibilidade de levarmos a arma para a polícia, mas segundo o mediador de conflito, essa seria uma atitude nada adequada, 
pois os traficantes locais iriam posteriormente pressionar a equipe para saber sobre o paradeiro da arma.

Essa situação gerou um desconforto muito grande em toda a equipe, ao ponto de levantarmos a possibilidade de Jonas não ser mais atendido em nosso projeto, e de ser encaminhado para o Conselho Tutelar. Porém, esse encaminhamento só poderia ser feito com a anuência da ONG que patrocinava o projeto do circo, e essa possibilidade nunca foi permitida pela instituição.

Por vários dias Jonas não compareceu ao seu atendimento. Passados pelo menos quinze dias, ele chegou num horário totalmente diferente do habitual. Disse que não queria ter faltado ao seu atendimento, mas que seu trabalho estava difícil, porque o traficante gerente da boca de fumo local, designou-o para ficar durante o dia e tarde em rondas pela favela. E que à noite, era para ele ficar com sua família. "Suas vindas começaram a ser "fugidas”, que ele dava de seu "trabalho" no tráfico de drogas”.

Sendo assim, os atendimentos de Jonas não puderam mais ter a constância dos horários. Continuávamos duas vezes na semana, porém, sem horário e dia certos. Jonas chegava, não mais com a arma, e começávamos a sessão. Nesses encontros, Jonas começou a se queixar da vida que vivia, ou seja, estar no tráfico não era aquilo que sonhara em sua vida. Dizia que quando via um garoto na praia, junto com a família e com amigos, sentia vontade de ser o garoto, pois parecia que os outros tinham tudo na vida, enquanto ele não tinha nada. O "tudo" de Jonas não eram objetos, mas sim, as relações de afeto que percebia quando observava uma família, pais e filhos, brincando ou conversando. Para ele, essa realidade era distante da sua, na qual desde pequeno, aprendeu que a convivência com a família era sinônimo de ser surrado e humilhado.

O trabalho com Jonas nos atendimentos, muitas vezes, acontecia do lado de fora da sala, onde as aulas de circo social estavam acontecendo. Aulas que eram pautadas no lúdico e atividades circenses. Jonas se entusiasmava muito com as aulas, por vezes indo para o meio das crianças e adolescentes participar de alguma atividade proposta. Era a maneira de introduzir Jonas em um mundo completamente diferente do que ele conhecia. Quando o circo social se apresentou para o publico da favela, Jonas estava entre as fileiras da frente e foi chamado para participar de uma cena, no meio do espetáculo. Isso fez com que aquele menino 
com 12 anos se percebesse como a criança que era, e começasse a acreditar que poderia pertencer a outros grupos que o acolheriam. O tráfico deixava de ser a sua única opção.

Em uma de nossas sessões, Jonas trouxe a fala de que sua namorada estava lhe traindo, e por isso, havia batido nela. Indagamos o motivo para bater em uma mulher, e ele disse, "eu sou homem e ela tem que me respeitar” (sic). Essa fala de Jonas foi base para várias sessões, em que pudemos traçar junto com ele a similaridade dele com a figura do pai, quando espancava sua mãe e irmã. Segundo ele, os episódios de fúria com a namorada eram menores. Ele se lembrava de sua mãe quando ia bater na namorada, e conseguia se conter. Orientado a conversar mais com a namorada, Jonas dizia que as conversas eram boas, mas quando ela começava a “crescer para cima de mim” (sic), ele saía de perto e deixava a menina falando sozinha.

\section{Ano 2011 a 2012}

Jonas chegou à um dos atendimentos muito cabisbaixo e triste. Já estava habituado ao procedimento do atendimento: entrava, sentava-se na cadeira e começava a falar. Ainda que sua comunicação fosse pautada nas gírias de adolescentes, e pouco sabendo nomear o que sentia, apenas disse estar "com alguma coisa ruim na cabeça" (sic), se referindo aos pensamentos que lhe vinham, e que lhe causavam incômodo. Esses pensamentos tinham a ver com a maneira que começava a falar mais de sua vida em família e seu envolvimento com o tráfico de drogas.

Durante as sessões, Jonas em alguns momentos, comoveu-se com choros e ataques de fúria, batendo com a mão na parede da sala de atendimento, sobre tudo quando se referia ao que acontecia em sua vida. Disse certa vez que seu pai não o amava e que sua mãe não tinha muito que dar, por esse motivo aceitou entrar no tráfico. "O tráfico é bom tia, eu gosto, porque lá eu sou respeitado como homem, eu sou um homem e lá ninguém quer saber se eu só tenho 12 anos. Meu pai rouba dinheiro da minha mãe e rouba o dinheiro que é para alimentar minha irmã e minha mãe. Não posso deixar isso não, tenho vontade de matar ele." (sic).

Nessa época, Jonas começou a frequentar o circo. Não frequentava 
assiduamente, pois tinha que se dedicar ao trabalho no tráfico local. Jonas começou a permitir que o circo, tal qual a terapia, começasse a ter mais espaço em sua vida emocional. Ele ia ao circo social e deixava de estar em seu atendimento psicológico. Em alguns momentos de seus atendimentos, Jonas chegou a chamar a psicóloga de "mãe" (sic). Percebemos em Jonas, nesse momento, o quanto ele se sentia acolhido e seguro no atendimento, e que isso estava sendo estendido também a sua participação no circo social. O vínculo amoroso que se formava no decorrer dos atendimentos começou a abranger também a participação dele nas atividades do circo.

Quando o paciente, neste caso, chama a terapeuta de mãe, então percebemos que nasceu no vinculo terapêutico, uma relação de confiabilidade. O paciente pode então, a partir do mecanismo da transferência, reencontrar a mãe no lugar do terapeuta.

Com o passar do tempo, a participação Jonas tornou-se mais frequente nas oficinas do circo e ele começou também a se interessar pelas atividades. Suas vindas às oficinas também eram no momento em que conseguia sair de seu posto de trabalho e vir para à aula. Às vezes, Jonas entrava na oficina faltando pouco tempo para seu término. O professor então foi orientado pelo serviço de psicologia, a permitir que o adolescente entrasse a hora que pudesse, sem ser chamado a atenção por isso. Essas vindas de Jonas às aulas faziam parte de seu atendimento e tratamento psicológico.

Jonas sempre foi muito bem acolhido pelo grupo e recebia incentivos afetuosos por parte dos professores e alunos. Esses incentivos durante o atendimento psicológico sempre eram lembrados e colocados como a possibilidade de que Jonas pudesse fazer parte de um local que o acolhera e o compreendera bem mais do que no tráfico. Além disso, havia a possibilidade dele receber uma bolsa auxílio se continuasse nas atividades.

O tráfico era um trabalho que trazia rentabilidade para Jonas e para a família, mas a possibilidade de entrar no circo social, receber uma bolsa, se apresentar em público, e participar desse grupo começou a fazer sentido para Jonas.

Durante quase um ano de idas e vindas às sessões psicológicas e ao circo social, Jonas chegou ao atendimento com a psicóloga e disse que estava saindo do tráfico, pois isso não poderia ser mais uma vida para ele e sua família. 
Contou que um de seus companheiros havia sido morto na sua frente, e que isso não era vida para ninguém. O mesmo homem, que Jonas por muito tempo entendia como sendo alguém que o acolhera e lhe dera um posto de homem e responsabilidades, foi quem tirou a vida de um de seus amigos do tráfico. Nesse momento, Jonas percebeu que isso poderia acontecer com ele também. A confiança de Jonas para com o tráfico de drogas tinha sido finalmente abalada, e foi, a partir desse abalo, que os atendimentos e o circo, começaram a fazer parte da vida dele como uma real possibilidade de acolhimento e mudança em sua vida.

Jonas disse que gostaria de participar mais efetivamente do circo social e quem sabe, ter uma chance para receber uma bolsa. Dissemos que ele teria que se empenhar e vencer muitas dificuldades em sua vida para escolher e assumir, com a pouca idade que tinha, a sua opção. Isso foi compreendido como um grande desafio para Jonas, que começou a frequentar os horários marcados e dias de sua terapia e, diariamente, frequentar o circo, e participar das atividades propostas.

Para que Jonas pudesse sair do tráfico, houve uma mediação entre um de nossos mediadores de conflito e o tráfico de drogas local. A saída de Jonas teria que acontecer, mas para isso, era necessário pedir que nem o menino, nem sua família fossem punidos. As conversações se iniciaram e Jonas foi liberado do seu trabalho no tráfico, através do mediador de conflitos ex-traficante local, que fazia parte da equipe que trabalha no projeto do circo social. Toda essa trajetória da mediação foi fortemente acompanhada por Jonas e pela família. Jonas dizia sentirse em uma família dentro do projeto, e que agora compreendia o que era ser "um menino feliz" (sic). Estava reconhecendo o acolhimento e a afetividade amorosa que recebeu por todos os momentos que aceitou entrar em tratamento e participar do grupo do circo. Finalmente se reconhecia como um menino, uma criança amparada.

\section{Término 2012 a 2013}

Aos 13 anos, Jonas foi chamado para participar do circo social, e avisado de que receberia uma bolsa de participação, mas que teria que voltar a estudar e continuar seu atendimento com a psicologia. Frequentava à Escola no horário noturno, pois não havia mais vagas pela manhã. É importante ressaltar que 
Jonas, desde que entrou para o tráfico de drogas, havia parado de frequentar a escola, já que isso o atrapalhava em seu trabalho. A equipe social do projeto conseguiu matriculá-lo em uma Escola próxima. A mãe, com a ajuda de moradores, conseguiu participar dos encontros com a psicóloga e por vezes com a assistente social, e sua participação foi fundamental para que Jonas conseguisse sair do tráfico. A partir daí, a família vislumbrou uma vida com possibilidades de melhora em todos os sentidos.

O pai de Jonas, não apareceu mais na favela, e consequentemente, na vida da família, durante o último ano e meio. Carla encontra-se inscrita em programas do governo tais como o Bolsa Família e espera ser contemplada com esse auxílio financeiro.

Hoje, Jonas está prestes a completar 14 anos, fazendo aniversário no inicio do ano. Tem uma bolsa auxílio pela participação no circo social de cerca de $\mathrm{R} \$ 700,00$. Com esse dinheiro, Jonas, que durante esses três anos não faltava suas sessões, por vezes chegando cedo e abrindo a porta para dizer que já estava ali, comprou uma placa para colocar na porta da sala de atendimento, com os dizeres: Lar Doce Lar, que foi mantida na porta desde que ele a trouxe.

Era comum nas sessões Jonas pegar os brinquedos, principalmente os jogos de tabuleiro, e brincar, fazer desenhos e depois arrumar a sala toda, já que sabia que outras crianças também recebiam atendimento. Uma das atividades preferidas de Jonas era montar histórias com os desenhos, como se fosse um gibi. Ele montava histórias com seus desenhos e, às vezes, com mosaicos que confecciona de pedaços de E.V.A. E gostava quando seus gibis eram lidos por outras crianças. Um de seus últimos gibis contava a história de uma criança abandonada por sua família e resgatada por super-heróis, e que mesmo não sendo filho dessa família, conseguiu também desenvolver superpoderes. Ao final de cada história, assinava seu nome e dizia que um dia iria vender muitos gibis desses pelo mundo. Jonas revelava sua própria trajetória de vida em seus gibis.

Jonas, atualmente, mantém uma caderneta de poupança feita por sua mãe, na qual deposita o dinheiro que recebe da bolsa e do cachê que ganha nas apresentações que o circo promove pela cidade, além de emprestar, por vezes, dinheiro para os amigos, e fazer sua vida financeira prosperar.

Diz sempre que o circo social e os atendimentos com a psicóloga 
mudaram sua vida, "Eu tava muito perdido" (sic). Jonas buscou sua melhora, pois sua luta diária, era percebida por todos que estavam à sua volta no circo, e em sua casa. Os amigos passaram a ser os companheiros do circo. Jonas também estava aprendendo a trabalhar na iluminação cênica dos espetáculos apresentados pelo circo, sendo chamado por muitos de “gênio"(sic) por aprender com grande facilidade e habilidade.

Carla, que vinha ao atendimento uma vez a cada quinze dias, desde que os atendimentos psicológicos começaram, diz que seu filho teve uma mudança muito significativa quando entrou para o atendimento com a psicologia e para o circo social, e que isso a deixa muito mais tranquila em relação ao destino da vida de seu filho. Porém, a mãe ainda teme o tráfico de drogas, que apesar da presença da UPP, ainda continua seus trabalhos. "Eu às vezes penso que meu filho pode voltar a qualquer momento para o tráfico, porque os garotos ficam próximos da minha casa. Mas se isso acontecer, eu venho aqui correndo falar com a senhora e sei que a senhora vai me ajudar” (sic). A fala da mãe temerosa por um retorno do menino ao tráfico, de certa maneira, nos auxiliou durante todo o atendimento.

O tráfico de drogas na favela não cessou, apesar da presença da polícia da UPP. Ao cair da tarde, era evidente a presença dos meninos armados dentro da favela, em suas ruas estreitas e becos. Eles já não ostentavam as armas como antes faziam, mas mesmo assim, não se podia passar por determinados lugares na favela, sem ter que pedir licença, ou ser abordado por algum menino armado. Ou seja, tal qual Jonas fora, por um soldado do tráfico local.

Durante todos os atendimentos, a família foi acompanhada pela psicóloga, processo que durou três anos. A mãe, que, no começo dos atendimentos de Jonas com a psicologia, tinha um discurso muito empobrecido de afetividade. Hoje, depois de três anos de atendimento, pôde expressar-se ao dizer para Jonas que ele era uma pessoa importante em sua vida, pois ajudava a comprar comida para a casa e lhe dava paz, estando fora do tráfico e que isso lhe fazia uma mãe muito feliz.

Essa mãe, apesar de ter tido uma vida dolorosa, com uma história de muitas perdas, e um marido violento que sumiu de casal; aprendeu a ser um continente para seu filho; buscando manter com ele um contato mais próximo, dando-lhe mais atenção e afetividade. Ela finalmente conseguiu dar um holding 
para seu filho. Com o tempo, foi aprendendo a ser uma mãe protetora e amorosa. 


\section{6 \\ Análise e Discussão dos Casos Clínicos}

Ressaltamos que esta discussão de casos em momento algum tem a pretensão de que estes sejam compreendidos apenas por uma única orientação teórica, mesmo que, a teoria de Winnicott sobre o desenvolvimento maturacional infantil e da tendência antissocial tenham sido o norte para a compreensão dos casos clínicos apresentados.

A eleição e construção das categorias de pesquisa foram duas. Os casos mostraram que, ambos os pacientes, indicaram duas categorias. A primeira categoria foi à violência que sofreram de formas diversas, que marcou fortemente suas vidas. E a segunda categoria, emergiu do fato de responderam a isso com os atos antissociais e delinquentes.

Paulo, nos atendimentos, lembrava "eu sempre fui assim tia, ninguém pode comigo (...) “a vida é minha e eu faço dela o que eu quiser”, (...) “"eu pego mesmo tia, tudo otário os turistas, é facinho, eu sou do morro tia, eu faço o que eu quiser, tudo otário lá embaixo (fora do morro)". No caso de Jonas, "eles me tratam como homem tia, eu sou um homem e não um menino” (...); “eu vou cuidar da minha mãe e da minha irmã, lá na boca a gente é tudo soldado, tudo irmão" (“...)”. Eu gosto dos meus tios de lá (tráfico), porque eles gostam de mim “(sic)”.

O pedido de socorro revelado nas ações desses dois jovens, apareceu quando Paulo retornou à favela e começou a se juntar com outros meninos e meninas para saquear bares e entrando nas casas de moradores pela janela para roubar. Paulo voltou à favela, depois do último período em que foi para o interior com a avó, com um comportamento não mais antissocial, mas delinquente. Era comum ver Paulo na praia de Copacabana praticando pequenos roubos de bolsas e relógios de turistas. Segundo ele, era mais fácil pegar de turistas: "tia, isso é mamão com açúcar” (sic). Ou quando Jonas trouxe a fala de que: "o tráfico é bom tia, eu gosto, porque lá eu sou respeitado como homem, eu sou um homem e lá ninguém quer saber se eu só tenho 12 anos. Meu pai rouba dinheiro da minha o dinheiro que é para alimentar minha irmã e minha mãe. Tia eu não posso deixar isso não, tenho vontade de matar ele.” (sic). 
Ambos tiveram suas vidas atravessadas pela violência de tal maneira, que não conseguem se diferenciar dela. Achavam normal e legítimo fazer o que faziam. São crianças carentes de uma provisão ambiental adequada, e ambos, em algum momento do desenvolvimento emocional, vivenciaram uma ruptura drástica e um congelamento em alguma das fases que toda criança, seja ela pobre ou rica, passa. São as fases do desenvolvimento maturacional, segundo a teoria de Winnicott.

Ambos os casos descritos, tanto de Paulo como de Jonas, tiveram como categoria proximal a violência que viveram em idades precoces. Em consequência disso, apresentaram os comportamentos antissociais e delinquentes.

Aparentemente, ambos não tiveram a figura da mãe suficientemente boa e continente no inicio de seu desenvolvimento emocional. Como pudemos ver estas mães não tinham condições emocionais para tal. Paulo, tendo sido retirado de sua mãe, ainda recém-nascido; seu pai o tendo tirado da mãe no presídio e o levado para casa, entregando-o à avó, que não pôde lhe dar a adequada maternagem - ela mal conseguia cuidar de si mesma. Ela não tinha como cuidar do pequeno neto e suprir as necessidades que a criança solicitava.

No caso de Jonas, a mãe não tinha forças, em função de sua doença, para cuidar dele. Muitas vezes a criança estava chorando de fome, porque sua mãe não sabia amamentá-lo adequadamente ou não estava próxima da criança. O pai, embriagado, costumava andar com ele nos braços, em algum lugar da favela. As necessidades de provisão não puderam ser atendidas nos momentos da tenra idade.

Essas mães, aparentemente, não conseguiram experimentar a preocupação materna primária, tão importante para que a mãe possa amparar e suprir as necessidades da criança. Podemos fazer a hipótese de que, em suas vidas, a função de ser mãe, aparentemente nunca tenha sido realmente internalizada. A mãe fracassa, falha, nesse momento, não conseguindo ser o continente que a criança necessita. O fracasso se refere às adaptações sucessivas da mãe que tem que atender às necessidades físicas, corporais e emocionais do seu filho.

No caso de Paulo, por várias vezes tivemos hiatos, descontinuidades importantes em sua trajetória no atendimento psicoterapêutico. Depois de cada interrupção no atendimento, o comportamento de Paulo ganhava tons variados, como os furtos, os roubos, o vestir-se e comportar-se de maneira feminina. Forma 
feminina que nos apontou para uma verdadeira defesa contra todo o horror que passou em tão terra idade. Dessa forma, expressava sua dor e desamparo emocionais. O fato de ter presenciado o bárbaro assassinato do pai, quando estava apenas com três anos de idade; o desamparo de sua família; mãe e a avó que não puderam lhe dar o suporte emocional e físico necessários; para que pudesse superar toda a violência que viveu. Ele escutava sempre da mãe e da avó que seria como o pai, um marginal condenado à morte. Uma sentença de morte anunciada e de uma vida feita para a violência. Ao mesmo tempo, era muito parecido fisicamente com o pai, carregava o nome dele, escolhido por sua mãe, para homenageá-lo! Mensagens ambíguas, que o intimaram subjetivamente a procurar uma saída para não enlouquecer. Esses são fatores que certamente contribuíram para que Paulo passasse a se vestir de menina e se intitulasse Paula. A defesa de Paulo contra tamanha violência e desamparo vividos, foi construir uma identidade feminina.

O lugar da mulher nessa família era menos estigmatizado. A irmã mais nova, filha do mesmo pai, era considerada “uma criança boa”, pela mãe e pela avó. Na ocasião em que Paulo virou Paula, sua mãe deu à luz a mais uma menina. A chegada de mais uma mulher na família certamente contribuiu para que Paulo achasse inconscientemente que, aproximando-se dessas figuras, estaria a salvo, ou seja, estaria longe da possibilidade de se transformar no que havia de mais perigoso em sua vida, que era ser como o pai. Ser como o pai, era estar morto. Essa identificação feminina inconsciente, como dissemos, foi algo reativo às inúmeras situações traumáticas vividas por ele. Sendo Paula, imaginava poder conseguir um lugar de acolhimento nessa família.

Vários fatores já mencionados, fizeram que Paulo tenha se tornado uma criança com comportamento delinquente, agressivo e que tenha perdido todo e qualquer interesse em manter contato com o circo social e com a terapeuta: as interrupções nos atendimentos, por conta das diversas vezes que a avó viajava com ele e, que, impossibilitava a continuidade do tratamento; o fato da família, em nenhum momento dos atendimentos psicológicos demonstrar qualquer tentativa de reparação em relação aos cuidados, afetos, carinhos para com Paulo e principalmente, a falha da provisão ambiental suficientemente boa dessa família.

Lembremos que na teoria de Winnicott, quando a mãe falha continuamente em atender as necessidades do bebê, o que ocorre é um 
recolhimento do núcleo do self que tenta se defender ou se proteger das invasões do ambiente, provocando distúrbios psíquicos graves em termos de desenvolvimento maturacional. O núcleo do self sofre uma cisão (split). É isso o que ocorre na existência de doenças psíquicas graves, tais como esquizofrenia adulta ou infantil, estados esquizóides ou borderlines, ou até mesmo na presença de tipos clínicos com “falso self”. O indivíduo que sofreu uma ruptura do núcleo do self, provocado por constantes e reiteradas falhas ou invasões ambientais, não teve a possibilidade de fazer uso do objeto subjetivo precisando criar uma grande estrutura defensiva para conseguir operar a cisão da personalidade. A cisão da personalidade ocorre no momento em que o bebê mais dependia da provisão ambiental - na dependência absoluta, e ela é então, decorrente de um choque traumático proveniente do ambiente materno. Neste tipo de clivagem da personalidade e do ego, o núcleo do self teve que se constituir defensivamente, operando para isso um falso self. Ou seja, desenvolvendo patologias.

Ter sido obrigado a assistir a brutal morte de seu pai pelos traficantes, aos três anos de idade, foi um acontecimento traumático, decisivo na constituição da vida psíquica de Paulo. Uma coisa é a perda da mãe, a outra, muito diferente, é perda do pai. Quando Paulo sofreu essa perda em termos do controle ambiental, ele sofreu danos severos em sua identidade, impulsividade, espontaneidade e possibilidade de criatividade. Nas sessões era comum ouvir: “Nem lembro do meu pai tia, me fala, para que eu vou lembrar? Ele não me ajudou em nada mesmo, dizem que morreu porque não prestava, bem feito, tinha que ter morrido mesmo!” (sic) . E Jonas ao dizer, “Tia eu odeio meu pai, ele só faz maldade comigo e com minha mãe, eu não aguento mais apanhar todo dia, todo dia é surra tia.” (sic). A figura do pai para os dois se misturou a um ambiente avassalador, aterrorizante, de morte e medo.

A figura de pai para Jonas, como pudemos perceber, não era aquela de autoridade de interdição pautada no carinho e suporte emocional, mas sim como a de um indivíduo que lhe causava dor e angústia. A relação de Jonas com o pai era pautada em agressões verbais com ameaças e espancamento diário. O pai alcoolizado nunca sustentou um lugar de continente e firmeza, nem tampouco de amparo para a mulher e seus filhos. O lugar que ocupou foi, de pura e real violência. 
Tanto Paulo quanto Jonas, quando estavam nas sessões terapêuticas, começaram a experimentar uma relação com a terapeuta objeto (mãe objeto) e ambos testaram até que ponto esse novo ambiente (circo social e terapeuta) suportaria os ataques, a regressão ao ponto de congelamento da falha que ocorreu em alguma de suas fases de amadurecimento.

A confiança dessas crianças em um controle do mundo externo foi finalmente testada, ou seja, eles tentaram destruí-la, aniquilá-la, para que assim pudessem realmente confiar nesse mundo. Os meninos, então, se tornavam em muitos momentos durante a terapia, agressivos e difíceis. Paulo e Jonas estavam na realidade começando a experiência de sentirem-se reais e de existirem. É o pedido de S.O.S., que, no comportamento antissocial, precisa ser reconhecido pelo mundo, para que eles finalmente possam encontrar uma mãe ambiente, mãe continente, e suficientemente boa para suportar seus ataques. No caso, a terapeuta ocupou esse lugar durante os atendimentos.

Paulo, além de roubar, ou seja, de ter um comportamento delinquente, também agredia seus pares e em um determinado momento de sua vinda aos atendimentos, agredia até a própria terapeuta. “Agora vocês não vão mandar em mim, e eu vou ser quem eu quiser, tia eu odeio o circo!” (sic). A manifestação da tendência antissocial exigiu da terapeuta uma resposta fundamentada na realidade da esperança. Essa criança necessitava da disponibilidade pessoal da terapeuta em acolher as suas exigências com tolerância e sem retaliação, revelando, assim, a consistência do seu amor por ela.

Paulo testava esse ambiente acolhedor, ou essa terapeuta objeto o quanto podia. Era a maneira pela qual, ele conseguia suportar a possibilidade de tratamento para sua demanda. Já Jonas, apesar de todas as dificuldades, tentava manter essa relação com a terapeuta um pouco mais preservada. Embora, um dia, tenha trazido para o atendimento, uma arma de fogo. Precisou do interdito da terapeuta para que não permanecesse com ela. A maneira de Jonas testar esse ambiente era trazendo o que representava sua força diante dos outros, e principalmente em relação ao pai, já que era um soldado do tráfico, armado e pronto para atirar.

Essas experiências vividas por ambos em sessão terapêutica foram de extraordinária importância, pois somente através delas foi possível regredir à tarefa 
relativa à fase do desenvolvimento dos impulsos agressivos e destrutivos, descontinuada pela falha na provisão ambiental paterna. E foi somente experimentando os limites de um ambiente indestrutível, no caso as sessões com a terapeuta, que se tornou possível para essas crianças, perceber que existia uma fantasia de destruição, que era diferente da realidade.

A origem de toda delinquência e violência que foram encontradas nas experiências de Paulo, assim como a experiência de de-privação relativas às etapas iniciais do seu desenvolvimento, se constituíram na relação às falhas dos cuidados maternos, e da provisão advinda do pai. O pai que representa a sociedade, que precisa ser carinhoso e forte, e muitas vezes severo com a criança, impondo limites. A relação com a mãe, encontra a sua expressão no roubo, que aponta para a experiência de uma de-privação em um momento anterior à explosão agressiva. A provisão dos limites paternos, no entanto, estão diretamente relacionados ao desenvolvimento das moções agressivas e destrutivas. A recuperação de ambos é imprescindível ao processo terapêutico. As crianças que sofrem de uma deprivação, reagem a ela com um comportamento antissocial. Para Winnicott (1990), a resposta de comportamentos antissociais às experiências de de-privação, fazem parte da natureza humana. Aponta que toda a criança, mesmo aquela que teve uma provisão ambiental adequada, não esta imune à tendência antissocial.

Nas crianças menores, que estão próximas da origem de suas dificuldades e que, não se encontram nas condições sociais ruins, a tendência antissocial está inerentemente ligada à privação. Algo ia bem, mas de repente, começou a não ir tão bem assim. Alguma coisa modificou seu ambiente e que consequentemente alterou sua vida inteira. Essas modificações ambientais em crianças que já conseguem entender, “e conseguem em condições propícias reproduzir o que lhe ocorreu, a época de quando ocorreu, ou seja, já tem consciência do evento, quando em terapia são capazes de se lembrar, em termos de material produzido, no brincar, nos sonhos ou no falar, das características essenciais da privação original” (WINNICOTT, 2011, p.83).

Porém, a delinquência aponta para a existência de uma de-privação que não pode ser superada sem um suporte terapêutico. As defesas ficaram rigidamente estabelecidas, agravadas por ganhos secundários, como por exemplo, os roubos, ou o estigma “da criança sem conserto” (sic) pela escola. A criança que sofreu essa 
de-privação necessita ser prontamente atendida em seus apelos desesperados por socorro e por uma provisão ambiental adequada. Quanto mais rápidos e eficientes forem essas respostas a esses pedidos, maiores serão as chances de recuperação.

Para Winnicott (2011), uma criança que sofreu algum tipo de-privação é uma criança considerada desprovida. Seria simples pensar que dando a provisão que lhe falta, tudo estaria prontamente resolvido, mas não é essa a maneira como essas soluções acontecem na realidade. Necessitamos antes de tudo, enquanto psicoterapeutas, buscar compreender o que realmente se passava com a criança no momento dessa falha ambiental, estudando sua história pregressa.

Essa compreensão irá envolver não somente o aqui e agora da criança, suas relações parentais, e no caso de Paulo, com a avó, a mãe e irmãs. No de Jonas, com sua mãe o pai e irmã, bem como as condições que estavam presentes na época do fracasso desse ambiente. A investigação sobre, em que etapa do desenvolvimento emocional da criança, essa ruptura ocorreu. Somente assim pudemos começar a construir acessos para um tratamento psicoterápico viável para as crianças, e a consequente compreensão de suas vicissitudes.

Um tratamento como o de Paulo exigia tempo e principalmente disponibilidade da terapeuta em suportar as agressões vindas dele, para que pudesse finalmente exercer a confiabilidade nesse novo ambiente, em sua estabilidade e capacidade de suportar seus ataques. Guiada por impulsos inconscientes, “a criança espera conseguir levar alguém que a ouça a recordar-se do momento de privação ou da fase em que a privação consolidou-se numa realidade inescapável” (WINNICOTT, 1967, p. 89). Ou seja, Paulo precisava manter a esperança de encontrar alguém com quem pudesse estabelecer uma relação estável e segura, que servisse como meio (ambiente) para que ele pudesse experimentar o incomensurável sofrimento que vivenciou na época da de-privação. É por meio da regressão à dependência - propiciada pelo dispositivo terapêutico e pela pessoa do próprio terapeuta -- que a criança pode ser capaz de retornar à situação original do trauma e vivenciá-la de uma outra maneira, de re-significá-la. É esse retorno ao trauma original, buscado pela tendência antissocial, que exige do terapeuta, suportar uma imensa carga emocional.

Cabe pensarmos e indagarmos, até que ponto, em nossa praxis, a terapeuta estava pronta para suportar as infindáveis formas de sabotagem da família 
de Paulo em relação ao seus atendimentos. Pensarmos como essas sabotagens eram percebidas inconscientemente pela criança como mais uma forma de ataque à sua saúde mental.

Segundo Winnicott (1945), o terapeuta precisa falhar, assim como a mãe, mas a continuidade do tratamento é condição sine qua non para que o trabalho de reestabelecimento da confiança no ambiente possa acontecer. Aqui o ambiente falhou de novo. E de novo. Para que a trajetória psíquica de Paulo pudesse ter sido diferente, teria sido necessário que houvesse uma aposta por parte da família, nele, e no tratamento, o que não aconteceu. Paulo ficou sendo o representante de todo o mal, de toda a violência trágica sofrida pela família. Ele tinha o nome do pai e teria o mesmo destino que ele. Esse veredito, avalizado e reconfirmado pela escola, inviabilizou a permanência de Paulo com sua nova identidade feminina. No nome original, a mudança de identidade masculina para feminina promoveu inclusive a mudança para um outro nome. O nome verdadeiro, não citado aqui, pelo sigilo clínico, não tem o correspondente feminino. Esse pequeno e grande detalhe mostra como foi radical a defesa usada por Paulo. Para não ter o mesmo destino que seu pai, Paulo teve que ser outra pessoa.

Winnicott foi um dos poucos psicanalistas a enfatizar a importância do analista poder suportar um não saber em relação aos casos que atende. É isso que tornava o trabalho realizado com cada criança dentro do projeto, um trabalho único. Cada um que ali se encontrava, possuía suas peculiaridades e vicissitudes e nem sempre o acolhimento proposto pelo projeto e pelo atendimento psicológico pôde suportar a demanda emocional de dor e sofrimento que cada criança nos remetia, ao abrir as portas de sua vida emocional.

Para Winnicott (1954), o tratamento para a tendência antissocial se encontra na compreensão, do terapeuta, da significação e sentido desse comportamento. "Através da "regressão”, há então a possibilidade de se corrigir uma adaptação inadequada à necessidade do paciente na sua infância precoce” (op.cit., p.354). A maior parte do tempo, a criança que sofreu de-privação não tem esperança de poder restaurar o trauma original. Esse quadro somente se altera quando a criança começa a estabelecer uma relação objetal significativa com o terapeuta, e este consegue demonstrar sua compreensão profunda do paciente, interpretando-o corretamente e no momento certo, ou seja, dando-lhe sustentação e 
confiança.

Acredita-se geralmente que existe um certo perigo na regressão do paciente durante o tratamento psicanalítico. O perigo não tem origem na própria regressão, mas no fato de o analista não estar pronto para acolhê-la, bem como à dependência que dela faz parte. Quando o analista passa por experiências que lhe permitam confiar no manejo da regressão, é possível dizer que quanto mais rápida e completamente ele vier a acolhê-la, menos provavelmente o paciente precisará desenvolver uma doença como características regressivas (WINNICOTT, 1945, p.354).

O que Jonas apresentava quando se comportava de forma antissocial, agressiva, e em relação aos roubos de Paulo, tratava-se de uma carência relativa às falhas na provisão ambiental. Segundo o autor, “a vida é inerentemente difícil e nenhuma criança pode evitar a revelação das provas e de suas dificuldades”. Em Winnicott (1946), para questão do roubo, o autor postula que:

Ser roubado é o mesmo que roubar, e é tão agressivo quanto. Ser fraco é tão agressivo quanto o ataque do forte ao fraco. Assassinato e suicídio são fundamentalmente a mesma coisa. E o mais difícil de tudo isso, possuir é tão agressivo quanto apoderar-se vorazmente. Na verdade possuir e o apossar-se formam uma unidade psicológica, cada qual ficando incompleto sem o outro. Isso não implica em dizer que possuir e adquirir sejam bons ou maus (WINNICOTT, 1950-55, p. 288).

Levisky (2011) aponta que tanto a criança quanto o adolescente podem roubar até mesmo pela tentação e inveja de possuir determinado objeto, porém, para o autor, o roubo tem um significado inconsciente, ou seja, ele é na realidade uma tentativa de resgate da "capacidade de buscar” (op.cit., p.313), o que lhe falta ou o que lhe foi tirado, no caso, os pais. Eles então tentam buscar em outros objetos - no caso dessas crianças, Paulo nos roubos e Jonas como soldado do tráfico - uma reação da parte do outro, uma reação que lhes dará sentido de existir, que os livra da angústia do desamparo "e da indiferença aniquiladora do self primitivo e da autoestima.”. É o pedido de S.O.S que se configura no comportamento dessas crianças.

Um ponto importante para Jonas, era ser aceito no tráfico como um adulto e não como uma criança. Era uma forma de interagir e assumir responsabilidades. De certa maneira, ter, ele próprio, o controle do manejo de um ambiente que sempre foi pouco acolhedor com ele. Já que em casa ele não era 
respeitado como ser humano, criança e filho, pôde receber essa consideração entre os traficantes, que lhe deram um falso acolhimento, e que lhe faziam sentir aceito, mesmo que ilusoriamente. Sua provisão ambiental sempre foi extremamente pobre, principalmente quando a mãe se omitia em relação às agressões verbais e espancamentos que Jonas recebia de seu pai. E o tráfico não o acolhia, mas deixava-o a mercê da morte.

Assumir tão precocemente a posição de homem era libertar-se de estar a mercê da ilusória proteção de seus pais. Como um homem, podia modificar aquele ambiente, como uma criança, nada podia fazer, além de ser uma vítima. Ser homem para Jonas consistia em ser dono do seu próprio destino e de sua família. Trabalhar no tráfico e ser reconhecido era justamente a maneira de se tornar proprietário de sua liberdade, e de dar um sentido para a sua vida.

As crianças e jovens que participam do tráfico de drogas encontram benefícios materiais e afetivos nesse grupo social que, bem ou mal, disponibiliza afeto, proteção, capacidades úteis para aquela comunidade que lhe assegura elevação da autoestima e o resgaste da capacidade de busca, ambas mobilizadas por apelos de necessidades inconscientes. (LEVISKY, 2011, p.314).

Adriana, mãe de Jonas, tentava proporcionar a ele um ambiente afetuoso, em suas tentativas de contato amoroso, apesar de sua doença e dificuldades físicas. Mas suas falhas contínuas em protegê-lo das surras do pai não deram ao pequeno menino a provisão de segurança necessária. Ele não foi protegido por uma mãe continente, que lhe desse holding, tanto físico quanto psíquico.

Todas as particularidades do cuidado materno que antecedem e advém depois do nascimento convergem para a composição do ambiente de holding, isto inclui a preocupação materna primaria da mãe que lhe possibilita oferecer ao bebê o necessário suporte egóico. Tanto o holding psicológico quanto físico são essenciais ao bebê ao longo de seu desenvolvimento e o serão por toda a sua vida. O ambiente de holding jamais perde sua importância (ABRAM, 2000, p. 135).

A partir dos encontros entre Adriana e seu filho no setting terapêutico, e com o contato que foi estabelecido entre eles durante as sessões, Adriana, apesar de suas dificuldades, proporcionava aos poucos e com grande dificuldade um ambiente de holding necessário para que Jonas pudesse regredir a etapas de seu desenvolvimento maturacional. Para, a partir daí, poder significá-lo e vivenciá-lo 
em um novo contexto, em um ambiente suficientemente bom. E assim foi gerada, nos atendimentos com a mãe, uma experiência de relação diferente, de intimidade entre mãe e filho, que é indispensável ao self, para que ele pudesse vir a se tornar ele mesmo.

Em muitos momentos na terapia, as atividades foram dirigidas para que os dois, mãe e filho, pudessem sentir a pele e o contato próximo um do outro, em pequenos toques nas brincadeiras. Como no jogo do tapete, onde ambos tinham que se posicionar de acordo com o que as peças e cores definiam mãe e filho e, a cada rodada, eles se abraçavam. E no momento em que acertavam alguma pergunta, vibravam felizes por terem unidos conseguido realizar a atividade proposta. Esses momentos eram experiências de mutualidade. Essa é a experiência resultante da experimentação pelo bebê, do sentimento de self.

Eram momentos onde percebíamos a experiência de mutualidade, pela qual o bebê começa a experimentar o sentimento de self. Trata-se então, de um fenômeno perceptivo que é diferente da percepção, já que é relativo à etapa inicial de fusão entre eu e o não-eu. Descobrir o ambiente, nesse momento, não significa, para o bebê, reconhecer a qualidade de externalidade dos objetos. Pela repetição das experiências de contato começa a haver um crescente 'conhecimento' que não é mental, mas é baseado na familiaridade que vai sendo construída através dos atributos experimentados.

A ênfase aqui, repousa na experiência de continuidade de ser e no enriquecimento do sentimento de self significados na relação afetuosa e de intimidade da mãe com Jonas e de dele com sua mãe. O jovem nessa experiência, podia se sentir integrado, capacitado subjetivamente a realizar uma ação criativa, tal como levar sua mãe no colo para colocá-la na cadeira de rodas. Jonas conseguiu comprar essa cadeira para ela com o dinheiro da bolsa auxílio que o projeto lhe proporcionou. "Eu acho que meu filho meu ama, porque eu amo muito ele, mas eu não sei falar direito. Ele é um menino bom, só precisava da senhora e de um lugar pra ficar longe do tráfico, isso aqui salvou meu filho.” (sic).

Os contatos, que foram sendo mais espontâneos a cada sessão entre os dois, nos traziam a comprovação de que Jonas podia retomar a continuidade de sua existência e sentir-se real. Ele agora era tocado pela mãe de forma afetuosa, ele finalmente sentia a percepção de ser. "Sentir-se real é mais do que existir; é 
descobrir um modo de existir como si mesmo, relacionar-se aos objetos como si mesmos e ter um eu (self) para o qual retirar-se para relaxamento” (Winnicott, p. 161). Ele estava vivo na relação com a mãe, e isso era positivamente significante para a melhoria de sua vida interna, e consequentemente para a diminuição do comportamento delinquente e agressivo, que sempre usou como um verdadeiro escudo contra o ambiente aterrorizador que o rodeava.

É importante dizer que, a terapia não tinha um horário rígido, pois no tráfico de drogas, Jonas tinha horários previamente determinados, horário de trabalho. Jonas era atendido pelo serviço de psicologia nos dias marcados, mas com horários conforme a demanda. Esse tipo de trabalho foi realizado por Winnicott, no tratamento do caso Peggle em Winnicott (1987). Era um caso de uma menina psicótica cujos pais moravam muito distantes do consultório de Winnicott, e este realizou com a menina apenas oito sessões em um período de três anos. Winnicott monitorava os pais de longe por telefone, e quando se via necessidade de atendê-la, ele dizia aos pais para virem com ela à terapia. A terapia de Jonas era realizada em conformidade com o método “de acordo com a demanda” (op.cit., p.8).

No caso de Paulo, as inúmeras tentativas de estabelecermos um elo com a família, com a terapia e o circo foram frustradas. A família se esquivava, sempre demonstrando a sua impossibilidade de atender às necessidades de Paulo e principalmente, da importância de acompanhar, fisicamente, ou seja, de forma presencial, os atendimentos da criança.

O estabelecimento de um contato de intimidade a dois, entre terapeuta e paciente, é indispensável à emergência do self e à experiência de ser. Porém todas as tentativas de trazê-lo de volta para o atendimento também foram fracassadas. Paulo dizia que não precisava de tia alguma para conversar, pois agora "eu tenho meu homem para conversar comigo e saber da minha vida” (sic). Paulo, agora andava pelas ruas com o nome de Paula, usando maquiagem e roupas bem justas. Chegou a agredir tanto a terapeuta quanto a assistente social que estavam na sala de atendimento. Ao fazer isso disse: “agora vocês não vão mandar em mim, e eu vou ser quem eu quiser tia eu odeio o circo" (sic).

Quando se refere ao tratamento para crianças que sofreram algum tipo de de-privação, Winnicott (2005) é enfático ao dizer que não é psicanálise que 
estabelecerá mudanças significativas na vida da criança, mas a provisão de um ambiente especializado, que possua um objetivo terapêutico, capaz de dar uma resposta à altura das suas necessidades. Ele sempre disse que quando podia fazia psicanálise, quando não, fazia outra coisa.

Para Paulo, ter se transformado em Paula, foi a forma que encontrou para sobreviver à um ambiente que fracassava constantemente. Esse comportamento de Paulo, remete-nos à uma tentativa de se proteger de um mundo externo hostil e agressivo, ou seja, de poder existir, na forma de um falso self.

Paulo não teve a oportunidade de se encontrar no olhar, no toque, no gesto amoroso da mãe. O rosto dela não refletiu o seu rosto. Não houve o espelhamento. Ser Paula, no nosso entendimento, tornou-se a única maneira de sobreviver à falta desse amor.

O self verdadeiro precisa, a partir do contato com o ambiente facilitador, adquirir uma realidade psíquica pessoal que lhe permita sentir-se real, sentir que o mundo é real e experimentar a continuidade de sua existência. Onde o gesto espontâneo é o self verdadeiro em ação. Então, Somente o self verdadeiro pode ser criativo e sentir-se real segundo o autor. (WINNICOTT, 1962a).

Diante da falha ambiental, sofrida por Paulo, de forma intensa e constante, ao longo de sua vida, o falso self se constituiu como uma tentativa de substituição do ambiente e das funções materna e paterna que falharam. Ser como o pai, marginal, estigmatizado, agressivo e assassinado na sua frente, era uma tarefa impossível e indesejada para Paulo.

Winnicott (1958) mostrou que o falso self se submete ao ambiente como forma de proteger o verdadeiro self e que isso se inicia nas primeiras etapas do amadurecimento. Ser Paula era sobreviver a um ambiente agressor e hostil. Paulo precisava se defender. Ele buscou através da construção do falso self a preservação do seu verdadeiro self. “Através deste falso self o lactente constrói um conjunto de relacionamentos falsos, e por meio de introjeções pode chegar até uma aparência de ser real, de modo que a criança pode crescer se tornando exatamente como a mãe, ama-seca, tia, irmão ou quem quer que no momento domine o cenário” (op.cit., p.134).

O caso de Paulo não pode ser acompanhado pela terapeuta. A ONG que subsidiava o projeto social, não se propôs a ajudar a equipe na busca de outras 
formas de proteção para essa criança, no âmbito do serviço de assistência aos direitos da criança e do adolescente.

Para Winnicott (2005), pode-se “curar” a tendência antissocial por meio de um meio ambiente amoroso e firme, mas, de qualquer forma, acreditamos que essas crianças terão sempre a cicatriz desse sofrimento registrado em seu psiquismo. Elas sabem que sobreviveram às adversidades impostas a elas pela vida, mas não as esquecem.

A "prevenção da tendência antissocial começa em casa, por meio de uma maternagem suficientemente boa, em uma família e sociedade continentes, que ofereçam possibilidades de estruturação de um self individual e coletivo coeso, que integre suas contradições e seja capaz de lidar com os limites próprios e os da realidade” (LEVISKY, 2011, p.319). Como esperar dessas crianças que sofreram tamanhas dificuldades e dores advindas de casa, da escola, da realidade da favela onde moravam, e que conseguissem sózinhas, encontrar forças para lidar com os limites que a sociedade impõe sem transgredí-los?

Paulo e Jonas tiveram suas vidas marcadas por dor, sofrimento, provisão ambiental falha e inúmeras dificuldades de acesso à garantia de direitos. Por essas razões, cada atendimento realizado com essas crianças, foi uma verdadeira luta de forças da equipe social, e do projeto do circo, na maioria da vezes, contra todo o ambiente desfavorável que cercava essas crianças.

Para Paulo infelizmente a continuidade do tratamento foi impedida pela família. Sabemos que a participação dos familiares é fundamental na psicoterapia de crianças. Nesse ambiente onde a violência era a lei, não pudemos ir além dos limites impostos pela avó e pela mãe de Paulo. No entanto, mantemos a esperança de que algo da experiência de acolhimento seguro, afetuoso, tenha permanecido em sua memória como registro de que no mundo não há somente violência, tragédia, desleixo, desamor e maus tratos. Assim como sua experiência no Circo, onde pôde experimentar, ainda que por momentos breves, a alegria e a inocência de ser uma criança.

O encontro psicoterapêutico para Jonas configurou-se como o espaço potencial onde pôde começar a experimentar a criação do seu mundo, a partir da confiança na terapeuta e na equipe do Circo. Dessa forma, o existir pôde ganhar outro status. Passando a fazer parte da dimensão do real, o indivíduo passa a sentir- 
se real e também sentir o mundo como algo menos ameaçador, um lugar no qual é possível estar de verdade e com o qual é possível se relacionar. Onde a vida vale a pena ser vivida. 


\section{7 \\ Conclusão: \\ Da escuridão da violência à uma luz no fim do túnel}

Serem "capetas em forma de guri" é a certeza de que essas crianças estão a juntar pedaços de vida; que um dia elas esperam ser abraçadas por alguém que as ouça, em algum momento, de alguma forma.

Maia, Zamora, Vilhena e Bittencourt

Compreender os comportamentos desses jovens, que demonstravam agressividade gratuita muitas vezes entre seus pares e familiares, comportamento delinquente como roubos, furtos, só nos foi possibilitado a partir do método de estudos de casos múltiplos em psicanálise. Mas foi, sobretudo a riqueza teórica de Winnicott, que nos norteou na compreensão de seus atendimentos a essas crianças e adolescentes.

As crianças e adolescentes com as quais trabalhamos no projeto tiveram a violência destroçando suas vidas, que ficaram inexoravelmente marcadas pela marginalização e a estigmatização. Percebemos isso por ocasião das visitas institucionais realizadas, principalmente nas escolas. A fala dos professores já os rotulava como: “sem jeito, sem conserto", inclusive estimulando cada vez mais o sentimento de exclusão que eles viveram no seu pouco tempo de vida. Crianças que tiveram que lidar com as leis do tráfico de drogas, com as arbitrariedades e barbáries da polícia que teria a obrigação de lhes proteger. Que conviviam com esse turbilhão devastador: de um lado a violência perpetrada pelo tráfico, do outro, a violência proveniente da polícia e, para completar, muitos deles, com a violência do desamparo de suas próprias famílias.

Famílias que tiveram suas vidas ameaçadas por bandidos, e ou por policiais, que aprenderam a ter medo de lutar por seus direitos. Pessoas cada vez mais atravessados pela dor e pela impunidade presente nas favelas e morros da cidade do Rio de Janeiro. A polícia pacificadora UPP, que mantém um trabalho dentro da favela do Cantagalo, ainda está muito distante da realidade dos seus moradores, e, apesar de sua chamada "proteção e a busca pela paz”, continuam a implantar o medo através de atos abusivos. 
Vimos, então, que os sintomas antissociais significam tentativas de recuperação ambiental e indicam esperança. O fracasso delas acontece porque a criança não tem consciência do que está acontecendo, ela não sabe que, ao roubar, por exemplo, está buscando uma mãe suficientemente boa. A criança antissocial necessita, portanto, de um ambiente especializado que possua um objetivo terapêutico claro e bem definido. Ambiente que seja capaz de dar uma resposta fundamentada na realidade, à esperança que se expressa através dos sintomas. Winnicott (2012) nos aponta que isso precisa que ser feito por um período longo, cuidadoso, para que possa ser eficaz como tratamento.

Winnicott, em sua rica teoria, nos indica que a criança que sofreu deprivação é uma pessoa com uma história passada de experiências traumáticas. Segundo ele, a criança que sofreu de-privação, tem a possibilidade de se recuperar, dependendo do grau de perda de consciência, do ódio e da capacidade primária para amar.

Paulo, por não ter encontrando um ambiente onde pudesse se sentir amado, amparado e acolhido, não conseguiu sozinho, e nem com a ajuda da terapeuta, ter a possibilidade de uma vida com menos dor e violência. Não há possibilidade de mudança na vida de qualquer criança, quando a família não a sustenta emocional e fisicamente, a marginaliza e a ignora o tempo todo. Podemos afirmar, com Winnicott, que o incômodo causado pelo comportamento da criança antissocial, como Paulo, tem um valor que é positivado para o seu pedido de ajuda em relação à sociedade. É uma característica favorável que indica a presença da potencialidade de recuperação da fusão dos impulsos instintuais e da motilidade. Deixamos a pergunta: será que ainda há esperanças para Paula? Embora essa mudança de identidade tenha sido uma saída radicalmente defensiva com relação às situações traumáticas, sabemos que a adolescência é um momento de ressignificação de muitos conflitos. Mesmo considerando o quadro de falhas tão precoces e repetidas no desenvolvimento dele, podemos ter a esperança de que a relação de confiança que estabeleceu com a terapeuta sirva de referência para uma possível retomada de outro vínculo terapêutico. 
Jonas transcendeu o sofrimento, conseguiu o direito de ser uma pessoa respeitada e se sentir real. Conseguiu ter esperança na vida e senti-la como digna de ser vivida.

Por ter uma vitalidade emocional robusta, conseguiu, a partir do acolhimento vivido no atendimento e no circo, recuperar-se e demonstrar criatividade e vivacidade, apesar de suas atitudes antissociais e comportamento delinquente. Ele transcendeu a dor e o sofrimento, conseguiu o direito de ser uma pessoa respeitada e conseguiu sentir se real. Conseguiu ter esperança na vida e pôde senti-la como digna de ser vivida.

A questão do comportamento antissocial possui um significado muito claro para Winnicott. Ele a compreende por intermédio da atuação, e do direito a um lugar. Esse lugar é múltiplo, porque engloba por parte da criança, o colo e atenção da mãe, e também, um limite e significação de seus atos, pela figura do pai. Nos casos em que esses “pedidos” não são atendidos, o que costuma acontecer é: o aumento da sua área de ação no mundo marcado pela destrutividade. Winnicott marca que, podemos medir o grau de submersão na tendência antissocial, pelo incômodo que ela causa no meio. A destrutividade é a forma mais desesperada de tentar chamar atenção que uma criança pode lançar mão. Nesses casos, ela denunciaria a quebra na estrutura, teria se tornado um delinquente: “Diríamos que se trata da falta total de lugar, já que ela estaria dando um grito de SOS, para as estruturas mais vastas da sociedade, que seriam as leis do país, e procurando o limite nas barras de uma prisão” (VILHENA, MAIA, 2002, p.47).

O aparecimento da tendência antissocial inclui roubo, mentira, enureses noturnas ou diurnas, e de maneira geral, um comportamento desordenado e caótico. Esses comportamentos eram muito comum nas crianças que atendíamos no projeto circo social.

O projeto teve um papel de acolhimento e de provisão ambiental que significava ter compreensão das vicissitudes dessas crianças, adolescentes e de suas famílias. Por meio deste projeto, muitas crianças puderam ter suas vozes ouvidas, suas angústias compreendidas, e suas dores apaziguadas. Foi um lugar onde encontraram a possibilidade para fazerem "diferente” do que estavam habituados. 
Um lugar do qual eles se apropriaram como sendo parte de suas vidas; não mais um lugar de dores e desamparo; mas de esperança e criatividade.

A criatividade a que nos referimos diz respeito à realidade externa. Onde o ambiente suficientemente bom, é fundamental para o desenvolvimento de um indivíduo saudável, e o impulso criativo é algo presente em qualquer pessoa que se inclina de maneira saudável para algo ou realiza deliberadamente alguma coisa. Mas, quando um indivíduo tem dúvida sobre o valor de viver, esta dúvida está relacionada diretamente à qualidade e à quantidade das provisões ambientais no começo, ou nas fases primitivas da experiência de vida que experimentou.

Cada criança e adolescente citado nesta pesquisa, apesar de suas peculiaridades, com suas vicissitudes únicas, tiveram e têm como pano de fundo em suas vidas uma provisão ambiental inadequada, vivencias traumáticas decorrentes de um ambiente familiar empobrecido de acolhimento, de holding tanto psíquico, como físico. Vidas permeadas pela violência, fosse ela vinda do Estado, de casa, da polícia ou do tráfico de drogas. Violência essa que, por tantos anos tiveram que lidar em suas vidas. Pelo comportamento antissocial e delinquente, encontraram meios psíquicos possíveis para conseguirem lidar com o turbilhão de falhas ambientais, a impressão digital maior de suas vidas. Pedidos de socorro que poucos ouviam, que o mundo externo não compreendia, e que os mantinha no lugar marginal de ser e de existir.

Essa dissertação teve o intuito de demonstrar que, a partir de um ambiente acolhedor, de uma provisão adequada, do holding e principalmente, da compreensão da dor e do sofrimento das crianças que convivem com a violência: a violência estrutural, a violência familiar, a do tráfico de drogas, e da polícia. Ainda e apesar de tudo, elas demonstravam em seus atos antissociais e delinquentes, a esperança de que em algum momento poder encontrar um espaço de ressignificações, amor, acolhimento e possibilidade de mudanças.

O projeto social se tornou um ambiente suficientemente bom que permitiu a estas crianças e adolescentes, poderem reescrever suas vidas, por meio da criatividade e da esperança. Uma provisão ambiental adequada, tanto nos atendimentos do serviço de psicologia, quanto nas atividades do circo, foram o 
holding, o acolhimento e o continente para esses jovens. Foi à luz no fim do túnel para esse universo de crianças, vítimas e também sobreviventes, dessa realidade violenta, trágica e cruel. 


\section{8 \\ Glossário}

- AR-15: O AR-15 /M16 é uma das armas mais populares do mundo, ao lado dos FAL belga (utilizado pelo exército brasileiro), HK G3 alemão e pelo AK47 russo. Ela é considerada como uma das melhores armas do mundo. AR-15 é como é conhecido um fuzil de assalto, fabricado pela firma americana Colt, e muito usado no Brasil por membros do tráfico de drogas. Entrou em serviço no exército americano em 1958 e continua em uso até hoje. O AR-15 é considerado uma arma revolucionária, pois na sua fabricação são usadas várias peças de alumínio e plástico.

- Boca de fumo: Geralmente fica perto de riachos, esgotos ou barrancos, para dificultar a chegada da polícia. Em uma mesma favela, podem existir várias bocas e nem toda a droga fica aqui. Barracos conhecidos como "paiol" são usados para armazenamento de grandes quantidades e da munição da quadrilha. (http://super.abril.com.br/cotidiano/como-trafico-favela-44895.shtml)

- Bolsa Família: O Programa Bolsa Família é um programa de transferência direta de renda que beneficia famílias em situação de pobreza e de extrema pobreza em todo o país. O programa integra o Plano Brasil Sem Miséria, que tem como foco de atuação nos brasileiros com renda familiar per capita inferior a R \$ 70 mensais e está baseado na garantia de renda, inclusão produtiva e no acesso aos serviços públicos. (www.mds.gov.br)

- Caveirão: Carro utilizado pelo BOPE para entrar em favelas e morros do Rio de Janeiro. O carro é blindado, totalmente fechado, e que comporta cerca de 30 homens fortemente armados. Esse apelido foi dado por causa do símbolo do BOPE ser o de uma caveira.

- CRAS: Centro de Referencia de Assistência Social. Centro de Referência da Assistência Social é uma unidade pública estatal localizada em áreas com maiores índices de vulnerabilidade e risco social, destinada ao atendimento 
socioassistencial de famílias. O CRAS é o principal equipamento de desenvolvimento dos serviços socioassistenciais da Proteção Social Básica. Constitui espaço de concretização dos direitos socioassistenciais nos territórios, materializando a política de assistência social. O CRAS é o lugar que possibilita, em geral, o primeiro acesso das famílias aos direitos socioassistenciais e, portanto, à proteção social. Estrutura-se, assim, como porta de entrada dos usuários da política de assistência social para a rede de Proteção Básica e referência para encaminhamentos à Proteção Especial. (www.mds.gov.br)

- CREAS: O Centro de Referência Especializado de Assistência Social (Creas) configura-se como uma unidade pública e estatal, que oferta serviços especializados e continuados a famílias e indivíduos em situação de ameaça ou violação de direitos (violência física, psicológica, sexual, tráfico de pessoas, cumprimento de medidas socioeducativas em meio aberto, etc.) A oferta de atenção especializada e continuada deve ter como foco a família e a situação vivenciada. Essa atenção especializada tem como foco o acesso da família a direitos socioassistenciais, por meio da potencialização de recursos e capacidade de proteção. (www.mds.gov.br).

- Crias da favela: Pessoa que é originária da favela em que reside. Ou que nasceu na favela ou morro, e ainda possui vínculos familiares que residem no local.

- Dono da boca: Nome utilizado ao gerente da boca de fuma de uma favela. O dono da boca tem o poder de comandar os traficantes de determinada facção criminosa dentro da favela. Esse sujeito é eleito muitas vezes por seu comportamento agressivo e atos cruéis para com aqueles que não sucumbem as suas leis, ou seja, as leia do tráfico local.

- E.V.A ou EVA: Conhecido entre artesãos e artistas, como EVA, o Etil Vinil Acetato é aquela borracha não tóxica que pode ser, e é aplicada em diversas atividades artesanais. As placas de E.V.A. são de grande versatilidade, laminados em diversas cores, espessuras, durezas e densidades. Com o artesanato 
de EVA se pode criar lindas gravuras para decorar capas de livros e cadernos, e até quadros para decorar diversos ambientes. Para trabalhar com esse material emborrachado as ferramentas mais comuns são as tesouras, estiletes, colas e os que se inventar, mas não se deve esquecer que o importante é a criatividade e o acabamento das peças.

- Favela da zona sul: Termo que se refere a favelas próximas a prédios no Rio de Janeiro em uma área geográfica brasileira carioca, localizada ao sul do Maciço da Tijuca. Abrange os bairros tais como Botafogo, Catete, Copacabana, Cosme Velho, Flamengo, Gávea, Glória.

- Forno Micro-ondas: Os "desobedientes" da favela são castigados. Há punições curiosas como, por exemplo, ser amarrado em um poste ou até em grandes torres de televisão. As pessoas que acabam mortas têm normalmente os corpos queimados nos chamados micro-ondas - pessoas são colocadas dentro de pneus e queimadas vivas. Quem é expulso, tem a casa ocupada pelo tráfico, caso não tenha família na comunidade.

- Gatonet: Apelido dado há dois tipos mais comuns de pirataria. O primeiro é a instalação ilegal de cabos a partir da conexão de um usuário pagante. O outro é adotar decodificadores que permitem o acesso ilegal à programação ou aparelhos que ajudam a desbloquear canais que não estão incluídos no pacote pago pelo usuário do serviço.

- Guerra de B-Boys: B-Boy: Abreviação para "Break Boy”, "Beat Boy" ou "Bronx Boy". A palavra B-Boy foi primeiramente utilizada pelo DJ jamaicano radicado nos Estados Unidos, Kool Herc. Ele deu esse nome a todos os dançarinos do início dos anos 70, e "B-Boy” passou a ser uma designação a um grupo de elite de dançarinos que participavam as festas organizadas por ele. BBoying é o estilo de dança dos B-Boys, também conhecido como Breaking.

- Instituições sem fins lucrativos: Esse termo não constitui um modelo de pessoa jurídica adotada pela legislação brasileira. Ela é oriunda do termo Non 
Profit Institutions, utilizado em modelos de pesquisas e orientações internacionais sobre o Terceiro Setor, que passaram a ser utilizados pelo Brasil nas últimas décadas. As instituições são, de acordo com esta definição, pessoas jurídicas institucionalizadas (constituídas legalmente); privadas (que não fazem parte do Estado), sem fins lucrativos - ou seja, não distribuem lucros para seus administradores ou dirigentes ou auto administradas, ou dito de outro modo, gerenciam suas próprias atividades; ou ainda voluntárias, as quais podem ser constituídas livremente por qualquer pessoa ou grupo de pessoas.

- Mediador de Conflitos: Indivíduo que tem livre acesso aos traficantes de drogas locais ou de uma determinada facção. Esse sujeito tem como trabalho, fazer a mediação dos moradores com os traficantes, bem como a mediação entre traficantes e ONGs que trabalham próximas as zonas de conflito dos traficantes. A mediação tem objetivo, manter a paz entre os lados que se encontram em divergência.

- Meninos do Asfalto: Meninos e Meninas moradores de bairros de classe média ou média alta, tais como Humaitá, Ipanema, Jardim Botânico, Lagoa, Santa Teresa, Laranjeiras, Leblon, Leme, São Conrado, e Urca. Ou todo aquele que não mora na favela ou morro.

- Movimento: O movimento gíria utilizada para designar que a boca de fumo está funcionando, e os traficantes estão posicionados em suas respectivas tarefas dentro do tráfico de drogas.

- MUF: O Museu de Favela-MUF é uma organização não governamental privada de caráter comunitário, fundada em 2008 por lideranças culturais moradoras das favelas Pavão, Pavãozinho e Cantagalo. O MUF surgiu um ano antes da chegada da Unidade de Polícia Pacificadora - UPP.

- Terceiro Setor: é uma categoria sociológica de origem norteamericana e no Brasil, em geral, compreende as associações sem fins lucrativos ou 
organizações não governamentais (ONGs), resultantes da suposta dificuldade do Estado em promover ações sociais ou políticas públicas que atendam a população.

- X9: Termo usado na gíria das favelas, morros e guetos. Designação para aquela pessoa que trabalha para a polícia diretamente ou indiretamente, ou seja, pode ser um policial infiltrado em uma facção criminosa, como pode ser também um informante traficante, que por ganhos financeiros ou diminuição de uma provável pena de detenção a ser cumprida, passa informações sobre o tráfico de drogas local para o serviço de inteligência da polícia. O X9 é considerado criminoso dentro de uma facção do tráfico, pois houve a perda da confiança no sujeito. Quando descobre se a presença de um indivíduo desses, ele é imediatamente punido. Dentro das punições estão incluídas a expulsão da facção; da favela; e como consequência, a decretação da morte desse indivíduo. 


\section{9}

\section{Referencias Bibliográficas}

ABRAM, J. A linguagem de Winnicott. Rio de Janeiro: Revinter, 2000.

ALVES, M. H. M.; EVASON, P. Vivendo no fogo cruzado: moradores da favela, traficantes de droga e violência policial no Rio de Janeiro. 1. Ed. São Paulo: Editora Unesp, 2013.

ARENDT, H. Sobre a Violência. Rio de Janeiro: Relume-Dumará, 1994.

BATISTA, V. M. O medo na cidade do Rio de Janeiro: dois tempos de uma história. Rio de Janeiro: Revan, 2003.

BIRMAN, P. Favela é Comunidade? In: Silva, M. L. A. Vida sob cerco violência e rotina nas favelas do Rio de Janeiro. Rio de Janeiro: Nova Fronteira/Faperj, 2008.

BOGOMELETZ, D. Winnicott: Paixão, Compaixão e Humor. Para uma teoria Winnicottiana da delinquência - São Paulo: Artigo Redpsi Junho, 2008.

BURGOS, B.M., PEREIRA, L, F.A., CAVALCANTI, M., BRUM, M, AMOROSO, M.(2011). Desigualdade \& Diversidade- O efeito UPP na percepção dos moradores das favelas- Rio de Janeiro: Revista de Ciências Sociais da PUC-Rio, n ${ }^{\circ}$ 11, ago/dez pp. 49-98, 2011.

CONSElHO FEDERAL DE PSICOLOGIA. Código de Ética Profissional do Psicólogo. Brasília: CFP, 2005. Disponível em: http://www.pol.org.br/pol/cms/pol/legislacao/codigo_etica. Acesso em: 02 ago. 2013.

COSTA, J. F. O Medo Social. Reflexões para o Futuro. - Revista Veja 25, Anos. São Paulo: Editora Abril, 1993.

COSTA, J. F. A ética democrática e seus inimigos: o lado privado da violência pública, In: NASCIMENTO, E. P. (org.) Ética: Brasília - capital do debate - o século XXI. Rio de Janeiro/Brasília: Garamond/Codeplan, 1997.

COSTA, J. F. Violência e Psicanálise. Rio de Janeiro: Editora Graal, 2003.

DAHLBERG, L.L., KRUG, E. G. Violência: um problema global de saúde pública, Ciência e saúde coletiva, Revista: Red de Revistas Científicas de América Latina, el Caribe, España y Portugal Sistema de Información Científica. Ciência \& Saúde Coletiva, vol. 11, 2006, pp. 1163-1178, Rio de Janeiro: Associação Brasileira de Pós-Graduação em Saúde Coletiva Brasil, 2006.

DIAS, E, O. A teoria do amadurecimento de D. W. Winnicott. 2ed. São Paulo: DWW Editorial, 2012. 
IBGE. Censo 2010 aprimorou a identificação dos aglomerados subnormais. 15 de dezembro de 2011, Brasil. Disponível em: http://www.ibge.gov.br/home/presidencia/noticias/noticia_visualiza.php?id_noticia =2051. Acessado em 21 de Novembro de 2013.

LEJARRGA, A. N. O amor em Winnicott. Rio de Janeiro: Garamond, 2012.

LEVISKY, L.D. Tendências Antissociais: Teorias e práticas preventivas a partir do conceito de espaço transicional. In: Winnicott Ressonâncias. São Paulo: Primavera Editorial, 2011.

MACHADO DA SILVA, L. A.; LEITE M. P. Violência, crime e política: o que os favelados dizem quando falam desses temas? In: Sociedade e Estado, Brasília, v. 22, n. 3, p. 545-591, set./dez. 2007.

MAIA, M. V. C. M., ZAMORA, M. H. R. N., VILHENA, J. , BITTENCOURT, M. I. Crianças impossíveis - quem as quer quem se importa com elas? In: Psicologia em Estudo, Rio de Janeiro, 2007: V.12, p. 335-342.

MAIA, M. V. C. M. Um rio sem discurso: relato de um psicodiagnóstico. Trabalho de final de formação em psicoterapia infantil (mimeo). Brasília: Cepapsi, 2002.

MATTOS, R. C. As classes perigosas habitam as favelas: Um passeio pela crônica policial no período das reformas urbanas. Desigualdade e Diversidade: Rio de Janeiro, 2009: Revista de Ciências Sociais da PUC-Rio, $n^{\circ} 5$.

NETO, O. C., MOREIRA, M. R. A concretização de políticas públicas em direção à prevenção da violência estrutural. Rio de Janeiro, 1999: Ciência e saúde coletiva. V. 4, n. 1.

O.N.U. Handbook of National Accounting - The Handbook on Non-Profit Institutions in the System of National Accounts, (2003). Studies in Methods Series F., No. 91, New York: United Nations Press.

OUTEIRAL, J. Da tendência antissocial ao viver criativo. In: Winnicott Ressonâncias. São Paulo: Primavera Editorial, 2011.

RIOS, J. A. Aspectos humanos das favelas cariocas - $\mathbf{5 0}$ anos: Uma avaliação. In: Favelas Cariocas ontem e hoje. Rio de Janeiro: Garamond, 2012.

SILVA, L. A. M.. Vida sobe cerco. Violência e Rotina nas Favelas do Rio de Janeiro. Rio de Janeiro: Nova Fronteira, 2008.

SILVA, J. S. Um Espaço em Busca do Seu Lugar: as favelas para além dos estereótipos. In: SANTOS, M.; BECKER, B. K. “Território, Territórios - ensaios sobre o ordenamento territorial”. $3^{\text {a }}$ ed. Rio de Janeiro: Lamparina, 2007. 
SILVA, J. S. A cultura da esperança. Observatório de Favelas. 2004. Disponível http://www.observatoriodefavelas.org.br/observatoriodefavelas/acervo/view_te. php?id_text=10. Acessado em 22 de Outubro de 2013.

SILVA, K. M. Grupo Cultural Olodum. Fundação Carlos Chagas. 1997. Cad. Pesq. Disponível em: http://www.fcc.org.br/pesquisa/publicacoes/cp/arquivos/662.pdf. Acessado em 03 de Agosto de 2013.

SILVA, S. G. Direitos humanos: entre o principio da igualdade e a tolerância. Revista Praia Vermelha, 19(1), 2010a, p. 79-94.

- Preconceito e discriminação: as bases da violência contra a mulher. Psicologia, Ciência e Profissão, 30(3), 2010b, p. 556-571.

- Preconceito no Brasil contemporâneo: as pequenas diferenças na constituição das subjetividades. Psicologia, Ciência e Profissão, 23(2), 2003, p. 25 .

VALladARES, L. A Gênese da Favela Carioca - A Produção Anterior às Ciências sociais. FGV. Rio de Janeiro, 2000: Revista Brasileira de Ciências Sociais, v. 15, no. 44.

FGV, 2005.

A invenção da favela: Do mito de origem a favela.com. Rio de Janeiro:

VERZTMAN, J, PINHEIRO, P., SACEANU, P., VIANA, D. Patologias narcísicas e doenças autoimunes: discussão sobre a metodologia de pesquisa. São Paulo: Revista Latino Americana de Psicopatologia Fundamental, 2005.

VILHENA, J. , MAIA, M.V.C. Agressividade e violência: reflexões acerca do comportamento antissocial e sua inscrição na cultura contemporânea. Rio de Janeiro, 2002: Revista Mal-Estar e Subjetividade, 2(2), p. 27-5V8, set.

VILHENA, J. A Arquitetura da violência: reflexões acerca da violência e do poder na cultura. Rio de Janeiro, 2002, Cadernos de Psicanálise, V.18 (21).

VILHENA, J. ZAMORA, M.H., ROSA, C. Da lei dos homens à lei da selva. Sobre adolescentes em conflito com a lei. São Paulo, 2011: Revista Trivium. ISSN,p. 27-40.

VILHENA, J. ZAMORA, M.H., DIMENSTEIN, M., Sobre a vida dos jovens nas favelas cariocas. Drogas, violência e confinamento. Rio de Janeiro: Revista do Departamento de Psicologia da UFF, 2005, 16(1), p. 24-39.

VILHENA, J. BITTENCOURT, M.I., ZAMORA, M.H., NOVAES, J.V., BONNATO, M. Medos infantis, cidade e violência: expressões em diferentes classes sociais. Psicologia Clínica, Rio de Janeiro, 2011: V.23(2), p. 171-186.

VOLPI, M. O adolescente e o ato infracional. São Paulo: Cortez, 2010. 
WACQUANT, L. As prisões da miséria. Rio de Janeiro: Jorge Zahar Editor, 2001.

WINNICOTT, D.W. (1945) O desenvolvimento emocional primitivo. In: Textos Escolhidos: Da pediatria à psicanálise. Rio de Janeiro: Imago, 2000, p. 218-232.

(1947a) O ódio na contransferencia. In: Textos Escolhidos: Da pediatria a psicanálise. Rio de janeiro: Editora Imago, 2000, p. 277-287.

(1947b) A agressão e suas raízes. In: Textos Escolhidos: Privação e

Delinquência. Rio de Janeiro: Editora Martins Fontes, 2005, p. 93-101.

(1950-5) Agressão e sua relação com o desenvolvimento emocional In: Textos Escolhidos: Da Pediatria à Psicanálise. Rio de Janeiro: Francisco Alves, 2000, p. 355-374.

(1953). Objetos transicionais e fenômenos transicionais In: O brincar e a realidade. Rio de Janeiro: Imago, 1975, p. 13-44.

(1954) Retraimento e Regressão In: Textos Escolhidos: Da Pediatria à Psicanálise. Rio de Janeiro: Imago Editora, 2000, p.347-354.

- (1956a) Preocupação materna primária. In: Textos Escolhidos: Da pediatria à psicanálise. Rio de Janeiro: Imago, 2000, 399-405.

(1956b) A tendência anti-social. In: Textos Escolhidos: Da pediatria à psicanálise. Rio de Janeiro: Imago, 2000, p. 406-416.

- (1956c) Preocupação materna primária In: Textos Escolhidos: Da Pediatria à Psicanálise. Rio de Janeiro: Francisco Alves, 2000, p. 491-498.

- (1958). A psicanálise do sentimento de culpa In: O ambiente e os processos de maturação: estudos sobre a teoria do desenvolvimento emocional. Porto Alegre: Artmed, 1983, p. 19-30.

. (1962a) Provisão para a criança na saúde e na crise. In: O ambiente e os processos de maturação:. Porto Alegre: Artes Médicas, 1983, p. 62-69.

- (1964) Raízes da Agressão, In: Textos Escolhidos: Privação e delinquência (4a ed.). São Paulo: Martins Fontes, 2005, p. 102-110.

. (1967) A delinquência como sinal de esperança. In: Textos Escolhidos: Tudo começa em casa. São Paulo,: Martins Fontes, 2011, p. 81-92. p.173-180.

. O ambiente. In: Natureza Humana. Porto Alegre: Artes Médicas. 1990, Retraimento e Regressão. In: Natureza Humana. Porto Alegre: Artes Médicas. 1990, p.163-164.

Provisão para a criança na Saúde e na crise. In: Textos Escolhidos: O ambiente e os processos de Maturação. Porto Alegre: Artmed, 1993, p.62-69. 
(1987) The Peggle: relato do tratamento psicanalítico de uma menina.

Rio de Janeiro: Imago, 2011.

Privação e delinquência (4a ed.). São Paulo: Martins Fontes, 2005.

Explorações psicanalíticas. Porto Alegre: Artes Médicas, 1994.

Pensando sobre crianças. São Paulo: Artmed, 1996.

Ressonâncias. São Paulo: Editorial, 2012.

ZAMORA, M.H, CANARIM, C. Direitos de crianças e adolescentes: extermínio, racismo e o velho silêncio In: Sydow, E, Mendonça, M. L. (Orgs.). Direitos Humanos no Brasil (pp. 161-170). São Paulo, 2009: Rede Social de Justiça e Direitos Humanos. 